Федеральное государственное бюджетное

образовательное учреждение высшего образования «Пермский государственный медицинский университет имени академика Е.А. Вагнера»

Министерства здравоохранения Российской Федерации

Федеральное государственное бюджетное образовательное учреждение высшего образования «Уральский государственный медицинский университет» Министерства здравоохранения Российской Федерации

\title{
ЗНАЧЕНИЕ ВИТАМИНОВ В АКУШЕРСКО-ГИНЕКОЛОГИЧЕСКОЙ ПРАКТИКЕ
}

Учебное пособие

Пермь 2021 
Авторы: М.М. Падруль, А.А. Олина, Г.К. Садыкова, О.В. Прохорова, Т.А. Метелева, Е.В. Ширинкина, Н.В. Статных

УДК 618.2

3-761

\section{Рецензенты:}

доктор медицинских наук, профессор, зав. кафедрой акушерства и гинекологии № 2 E.В. Енькова (ФГБОУ ВО «Воронежский государственный медицинский университет им. Н.Н. Бурденко» Минздрава РФ); доктор медицинских наук, профессор, зав. кафедрой акушерства и гинекологии Е.Н. Кравченко (ФГБОУ ВО «Омский государственный медицинский университет» Минздрава РФ)

3-761 Значение витаминов в акушерско-гинекологической практике : учеб. пособие / М.М. Падруль, А.А. Олина, Г.К. Садыкова, О.В. Прохорова, Т.А. Метелева, Е.В. Ширинкина, Н.В. Статных. - Пермь, 2021. - 166 с.

ISBN 978-5-398-02525-5

В учебном пособии рассматриваются физиологические функции витаминов, а также влияние дефицитных состояний на женскую репродуктивную систему и перинатальные исходы.

Издание предназначено для студентов IV и V курсов лечебного, педиатрического и медико-профилактического факультетов по дисциплине «Акушерство и гинекология».

ISBN 978-5-398-02525-5

(C) Падруль М.М., Олина А.А., Садыкова Г.К., Прохорова О.В., Метелева Т.А., Ширинкина Е.В., Статных Н.В., 2021

(C) ФГБОУ ВО ПГМУ им. акад. Е.А. Вагнера Минздрава РФ, 2021 


\section{СОДЕРЖАНИЕ}

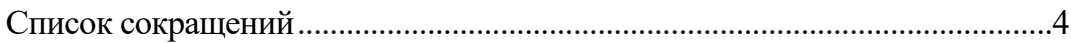

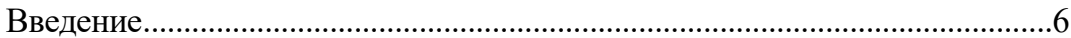

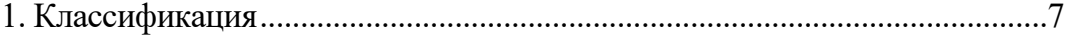

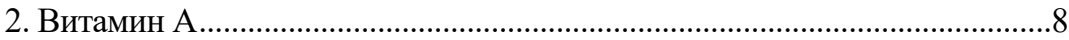

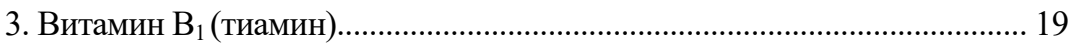

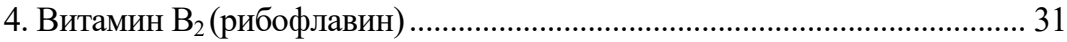

5. Витамин $\mathrm{B}_{3}(\mathrm{PP}$, ниацин, никотиновая кислота, никотинамид)............... 43

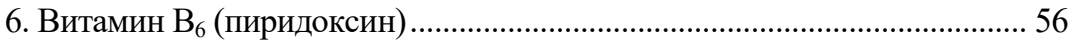

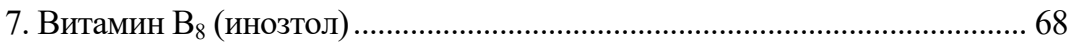

8. Витамин В

9. Витамин $\mathrm{B}_{12}$ (цианокобаламин) .............................................................. 94

10. Полиненасыщенные жирные кислоты (ПНЖК)................................... 108

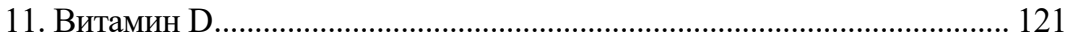

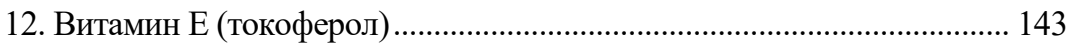

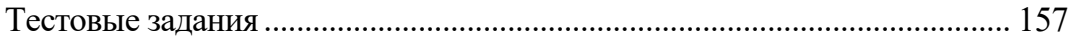

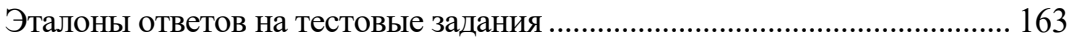

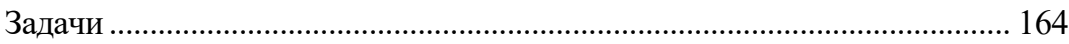

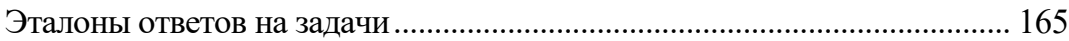




\section{СПИСОК СОКРАЩЕНИЙ}

АД - артериальное давление

АТФ - аденозинтрифосфат

АФК - активные формы кислорода

БАД - биологически активная добавка

Вит. - витамин

ВЭЖХ-МС/MC - высокоэффективная жидкостная хроматография тандемная масс-спектрометрия

ВПР - врожденные пороки развития

ГАМК - гамма-аминомасляная кислота

ГСД - гестационный сахарный диабет

ДНК - дезоксирибонуклеиновая кислота

ДГК - докозагексаеновая кислота

ДНТ - дефекты нервной трубки

ЖК - жирные кислоты

ЖКТ - желудочно-кишечный тракт

ИБС - ишемическая болезнь сердца

ИМТ - индекс массы тела

ИПГ-А - инозитол-фосфогликан-аденозинмонофосфаткиназа

МКБ - мочекаменная болезнь

НАД - никотинамидадениндинуклеотид

НАДФ - никотинамидадениндинуклеотидфосфат

РПП - рекомендуемое потребление с пищей

РСБ - ретинол-связывающий белок

ПНЖК - полиненасыщенные жирные кислоты

ПОЛ - перекисное окисление липидов

РЭ - ретиноловый эквивалент

ПАБК - парааминобензойная кислота

ПМС - предменструальный синдром

ПЭ - преэклампсия

ПР - преждевременные роды

РНК - рибонуклеиновая кислота 
СД - сахарный диабет

СПКЯ - синдром поликистозных яичников

СРО - свободнорадикальное окисление

ТГ - триглицериды

ТГФК - тетрагидрофолиевая кислота

ФАД - флавинадениндинуклеотид

ФЛ - фосфолипазы

ФМН - флавинмононуклеотид

ЦНС - центральная нервная система

$\mathrm{XC}$ - холестерин

$\mathrm{X}$-ЛПНП - липопротеиды низкой плотности

Х-ЛПОНП - липопротеиды очень низкой плотности

Х-ЛПВП - липопротеиды высокой плотности

ЭПК - эйкозапентаеновая кислота 


\section{ВВЕДЕНИЕ}

Открытие витаминов (вит.) стало крупным научным достижением в нашем понимании здоровья и болезней. В 1912 г. Казимир Функ впервые ввел термин «витамин». Главный период открытий начался в начале XIX в. и закончился в середине прошлого столетия. Загадка каждого витамина была решена благодаря огромной работе эпидемиологов, врачей, физиологов и химиков. В действительности, это была не мифическая история о научных открытиях, а медленный, постепенный прогресс, который включал в себя неудачи, противоречия, и некоторые опровержения. Исследования витаминов, которые связаны с клиническими проявлениями их недостаточности, начались, когда завершилось доминирование микробной теории болезней и догмы, согласно которой важны только четыре фактора питания: белки, углеводы, жиры и минералы. Вскоре клиницисты признали цингу, бери-бери, рахит, пеллагру и ксерофтальмию специфическими недостатками витаминов, а не заболеваниями, вызванными инфекциями или токсинами. Экспериментальная физиология на животных моделях сыграла фундаментальную роль в исследованиях питания и значительно сократила период, в течение которого человек страдает от дефицита витаминов. В конечном итоге именно химики выделили различные витамины, определили их химическую структуру и разработали методы синтеза витаминов. Наше понимание витаминов продолжает развиваться с начального периода открытия. 


\section{1. КЛАССИФИКАЦИЯ}

В зависимости от химической структуры и происхождения различают витамины гормональной природы, коферменты и антиоксиданты (табл. 1), а также водорастворимые и жирорастворимые (табл. 2).

Таблица 1

Классификация витаминов по функциональному признаку

(Спиричев, 2005; Боландер, 2007)

\begin{tabular}{|c|c|c|}
\hline Гормон & Кофермент & Антиоксидант \\
\hline $\mathrm{D}$ & $\mathrm{B}_{1}$ & $\mathrm{C}$ \\
\hline $\mathrm{A}$ & $\mathrm{B}_{2}$ & $\mathrm{E}$ \\
\hline $\mathrm{B}_{6}$ & $\mathrm{~B}_{5}$ & Бета-каротин \\
\hline $\mathrm{K}$ & $\mathrm{B}_{6}$ & \\
\hline & $\mathrm{B}_{12}$ & \\
\hline & Фолиевая кислота & \\
\hline
\end{tabular}

Таблица 2

Классификация водо- и жирорастворимых витаминов и витаминоподобных веществ

\begin{tabular}{|c|c|}
\hline Водорастворимые витамины & Жирорастворимые витамины \\
\hline $\mathrm{B}_{1}$ & $\mathrm{~A}$ \\
\hline $\mathrm{B}_{2}$ & $\mathrm{D}_{2}$ \\
\hline $\mathrm{PP}$ & $\mathrm{D}_{3}$ \\
\hline $\mathrm{B}_{5}$ & $\mathrm{E}$ \\
\hline $\mathrm{B}_{6}$ & $\mathrm{~K}$ \\
\hline $\mathrm{B}_{12}$ & $\mathrm{~K}_{1}$ \\
\hline $\mathrm{Bc}$ & $\mathrm{K}_{2}$ \\
\hline $\mathrm{C}$ & Холин \\
\hline $\mathrm{P}$ & Омега-3 ПНЖК \\
\hline $\mathrm{H}$ & $\mathrm{B}_{8}$ \\
\hline & $\mathrm{U}$ \\
\hline & Липоевая кислота \\
\hline & Оротовая кислота \\
\hline & $\mathrm{B}_{15}$ \\
\hline & Карнитин \\
\hline
\end{tabular}




\section{2. ВИТАМИН А}

Витамин А (ретинол) - представитель класса жирорастворимых витаминов, был открыт в 1913 г. Тогда двумя независимыми группами ученых было установлено, что желток куриного яйца и сливочное масло содержат определенное вещество, которое стимулирует рост животных. После этого, во время Первой мировой войны, были описаны многочисленные случаи ксерофтальмии и кератофтальмии, сухости и патологического ороговения склеры и роговицы глаз. При этом отмечалась взаимосвязь этих заболеваний с дефицитом сливочного масла в пищевом рационе. Выделенное из сливочного масла вещество первоначально обозначили как растворимый в жирах фактор А. Позднее, в 1916 г., его переименовали в вит. А. В 1921 г. были описаны признаки авитаминоза А, в 1931 г. описана структура вит., а в 1937 г. вит. А был получен в кристаллическом виде.

Помимо ретинола, вит. А включает в себя группу ретиноидов (витамеров - веществ, сходных по химическому составу и по оказываемому действию):

- ретиналь - альдегидная форма вит. $\mathrm{A}_{1}$;

- 3-дегидроретинол (вит. А 2 ) - транс-изомер ретинола;

- 3-дегидроретиналь - альдегидная форма вит. А 2 ретиноевая кислота - кислотная форма вит. $\mathrm{A}_{2}$;

- ретинилацетат, ретинилпальмитат - эфирные производные ретинола.

Это лишь основные формы вещества, наряду с которыми существует множество других ретиноидов, которые встречаются в природе или образуются в организме человека и млекопитающих в ходе метаболических реакций.

Функции многих из них остаются малоизученными. По названию основного компонента $\left(\mathrm{A}_{1}\right)$ данный вит. принято называть ретинолом. 
Химическое название ретинола - транс-9,13-Диметил-7(1,1,5-триметилциклогексен-5-ил-6)-нонатетраен-7,9,11,13-ол (в виде пальмитата или ацетата). Формула $-\mathrm{C}_{20} \mathrm{H}_{30} \mathrm{O}$. Данное химическое соединение представляет собой призматические кристаллы желтоватого цвета со специфическим запахом и температурой плавления $64^{\circ} \mathrm{C}$. Хорошо растворяется в жировых субстанциях и в других органических растворителях - этиловом и метиловом спиртах, дициклогексане, дихлорэтане. Практически не растворяется в воде. Нестоек во внешней среде - разрушается под действием атмосферного кислорода и солнечного ультрафиолета. Сходными свойствами обладают и другие вещества из группы ретиноидов.

\section{Основы метаболизма}

Всасывание ретинола, входящего в состав пищевых продуктов и препаратов, осуществляется в верхних отделах тонкого кишечника. В составе пищи поступает эстерифцированный ретинол (в виде эфиров) или каротиноиды. В просвете кишечника под действием поджелудочных и тонкокишечных ферментов эфиры ретинола разрушаются (гидролизируются, эмульгируются) с образованием свободного ретинола. Далее в слизистой оболочке тонкого кишечника при участии специфических ферментов вновь синтезируются эфиры жирных кислот ретинола. В таком виде он поступает в лимфу и в ее составе доставляется в печень. Здесь он депонируется в виде эфирного соединения ретинилпальмитата. Помимо печени, вит. А депонируется в легких, в почках, в сетчатке глаза, в надпочечниках, в молочных железах, в жировых тканях. Но все-таки основным депо является печень - здесь откладывается «про запас» до 80 \% вит. А в виде ретинилпальмитата. В случае недостаточного поступления или при его повышенном расходе этих запасов может хватить на 2-3 года. При необходимости ретинол из печени при участии цинка вновь освобождается и связывается с белком транстиретином. Далее он 
доставляется к клеткам органов и тканей, где вступает в соединение с ретинолсвязывающим белком (РСБ), который также синтезируется печенью.

Будучи по химической структуре спиртом, ретинол разрушает клеточные мембраны. Поэтому, прежде чем проникнуть в клетку, ретинол трансформируется в ретиналь и ретиноевую кислоту. В сравнении с ретинолом эти соединения более мягки, и не оказывают разрушающего действия на клетки.

Каротиноиды всасываются в кишечнике в 6-12-24 раза хуже (в зависимости от вида). Их трансформация в ретиналь осуществляется в клетках тонкого кишечника при участии специфического фермента, содержащего железо. Активность этого фермента зависит от состояния щитовидной железы. При ее недостаточной функции (гипотиреозе) этот процесс будет нарушен, и в организме будут накапливаться неутилизированные каротиноиды. При этом отмечается псевдожелтуха - окрашивание кожи и слизистых оболочек в насыщенно-желтый цвет. Витамин А лучше усваивается в комплексе с жирами и белками. Поэтому голодание, ограничительные диеты, увлечение растительной пищей - все это затрудняет всасывание вит. А и способствует его дефициту. Также затруднено всасывание ретинола при заболеваниях печени, желчного пузыря и поджелудочной железы, когда нарушается его эмульгирование и гидролиз. Невсосавшаяся часть вит. А в виде различных метаболитов удаляется через почки и кишечник

\section{Физиологические функции}

- Обмен веществ. При его участии в организме осуществляются многие окислительно-восстановительные реакции. Он регулирует все виды обмена веществ, стимулирует биосинтез белка, активизирует многие ферментные системы.

- Иммунная система. Ретинол - отличный иммуномодулятор. Он усиливает фагоцитарную активность лейкоцитов, 
стимулирует продукцию антител, участвует в синтезе интерферона и лизоцима. Тем самым он укрепляет иммунитет и повышает устойчивость организма ко многим видам бактериальных и вирусных инфекций. Это отличный антиоксидант, который препятствует повреждению тканей свободными радикалами. Антиоксидантное и иммуностимулирующее действие приводит к тому, что атипично измененные клетки вовремя распознаются, уничтожаются, и раковые опухоли не развиваются.

- Кожа и ее производные. Витамин А нормализует рост и деление эпителиальных клеток, препятствует избыточному ороговению. Также стимулирует синтез коллагена. В результате повышается барьерная устойчивость слизистых оболочек органов дыхания, желудочно-кишечного тракта (ЖКТ) и мочеполовой системы к действию патологических агентов. Кожа под его действием становится упругой, без морщин, отеков, пигментных пятен и других признаков старения.

- Сердечно-сосудистая система. Снижает образование низкоплотного холестерина, ответственного за образование атеросклеротических бляшек. Будучи антиоксидантом, он предотвращает склеротические и дистрофические изменения в миокарде.

- Костно-мышечная система. Повышает прочность связок, костей, хрящей. Способствует росту костей в длину.

- Эндокринная система. Ретинол участвует в синтезе надпочечниковых и половых гормонов. Также снижает уровень тироксина при его избыточной продукции щитовидной железой.

- Органы зрения. Оказывает колоссальное влияние на состояние зрительного анализатора. Ретиналь входит в состав родопсина. Этот зрительный пигмент обеспечивает светочувствительность рецепторов-палочек глазного дна. Предшественники ретинола, каротиноиды, увлажняют роговицу и склеру, препятствуют их патологическому ороговению (гиперкератозу), развитию катаракты. Этот вит. поддерживает в должном состоянии функцию желтого пятна - места наибольшего зрительного восприятия сетчатки глаза. 


\section{Содержание в продуктах, суточная потребность}

Отметим, что наибольшее количество вит. А содержится в продуктах животного происхождения, в то время как в зелени и овощах его не так уж и много. Хотя полностью ориентироваться на данные из таблицы не стоит. Дело в том, что в большинстве известных продуктов вит. А представлен не ретинолом, а его предшественниками, провитаминами, каротиноидами. Эти вещества включают в себя альфа-, бета- и гамма-каротин. Наиболее активным из них является бета-каротин. Это природный пигмент яркокрасного цвета, который в ходе обменных процессов трансформируется. Особенно много бета-каротина и других каротиноидов в овощах и фруктах, имеющих оранжево-красный окрас. Красная морковь богата не витамином А, как полагают многие, а его провитамином, бета-каротином. Вообще каротиноиды содержатся преимущественно в растительных продуктах, в то время как ретинолом богата животная пища - молоко, сыр, печень трески и печень млекопитающих животных, яичный желток. К тому же по своей активности бета-каротин во много раз слабее ретинола - 12 мкг этого провитамина эквивалентно 1 мкг ретинола (табл. 3,4 ).

Т а бли ца 3

Содержание в продуктах, суточные нормативы потребления*

\begin{tabular}{|l|c|c|}
\hline \multicolumn{1}{|c|}{ Категория } & Норма, мкг & Норма, ME \\
\hline Младенцы до 6 мес. & 400 & 1333 \\
\hline Младенцы с 6 мес. до года & 500 & 1667 \\
\hline Дети 1-3 лет & 300 & 1000 \\
\hline Дети 4-8 лет & 400 & 1333 \\
\hline Дети 9-13 лет & 600 & 2000 \\
\hline $\begin{array}{l}\text { Юноши-подростки старше 14 лет } \\
\text { изрослые мужчины }\end{array}$ & 1000 & 3300 \\
\hline $\begin{array}{l}\text { Девушки-подростки старше 14 лет } \\
\text { и взрослые женщины }\end{array}$ & 800 & 2667 \\
\hline Беременные женщины & $200-800$ & $667-2667$ \\
\hline Кормящие женщины & $400-1200$ & $1333-4000$ \\
\hline Пожилые & 800 & 2667 \\
\hline
\end{tabular}

П р и м е ч а н и е : * - в данной таблице МЕ - это международные единицы, отображающие активность препарата. Что касается вит. А, то здесь $1 \mathrm{ME} \mathrm{соответствует} \mathrm{0,3} \mathrm{мкг.}$ 
Содержание витамина А в продуктах питания

\begin{tabular}{|l|c|}
\hline \multicolumn{1}{|c|}{ Продукт } & Количество, мкг/100 г \\
\hline Рыбий жир & 25000 \\
\hline Печень трески & 30000 \\
\hline Индюшиная печень & 8000 \\
\hline Говяжья печень & 6500 \\
\hline Куриная печень & 3300 \\
\hline Сладкий болгарский красный перец & 2100 \\
\hline Зеленый перец & 18 \\
\hline Морковь & 830 \\
\hline Брокколи & 800 \\
\hline Масло сливочное & 680 \\
\hline Молоко & 30 \\
\hline Куриные яйца & 140 \\
\hline Зеленый салат & 550 \\
\hline Сыр & 265 \\
\hline Помидоры & 40 \\
\hline Зеленый горошек & 38 \\
\hline
\end{tabular}

\section{Эпидемиология}

Дефициту вит. А подвержено приблизительно 19 млн беременных женщин, главным образом в регионах Всемирной организации здравоохранения (ВО3) стран Африки и Юго-Восточной Азии.

\section{Симптомы дефицита и избытка}

Типичное проявление авитаминоза А - так называемая куриная слепота, или гемералопия, ухудшение сумеречного зрения. Также со стороны глаз будут отмечаться кератомаляция, ксерофтальмия, проявляющиеся размягчением, сухостью роговицы, покраснением склер с патологическим слезотечением. При этом острота зрения будет снижена, зачастую формируется катаракта. Кожа при этом сухая, шелушащаяся, с нездоровым 
цветом, гнойничковой сыпью и сниженной эластичностью. На такой коже создаются благоприятные условия для различных дерматитов, псориаза, экземы. Снижается барьерная функция слизистых оболочек внутренних органов. В сочетании с низким иммунитетом это будет сопровождаться частыми бронхитами, пневмониями, эрозивно-воспалительными процессами в ЖКТ, воспалением органов мочеполовой системы с недержанием мочи. Страдает репродуктивная система - нарушается менструальный цикл у женщин, у мужчин возникают признаки эректильной дисфункции и раннее семяизвержение. Появляются общая слабость, повышенная утомляемость, сонливость днем и бессонница ночью. Со стороны психики отмечается немотивированная раздражительность, тревога и депрессия. Повышается опасность злокачественных опухолей, особенно рака молочной железы, а у курильщиков и часто болеющих простудными заболеваниями - рака легких.

К дефициту предрасполагает:

- недостаток поступления ретинола и каротиноидов с пищей;

- заболевания ЖКТ, при которых нарушается его всасывание;

- дефицит некоторых других веществ, в частности цинка, витамина Е (токоферола), витамина $\mathrm{B}_{4}$ (холина).

Авитаминоз, как правило, развивается при сочетании этих неблагоприятных факторов.

Кроме того, при некоторых состояниях потребность повышается. Как правило, к подобным состояниям относят:

- физические нагрузки;

- психоэмоциональные стрессы;

- период роста и полового созревания;

- рентгенологические исследования;

- прием препаратов, снижающих уровень холестерина;

- сахарный диабет;

- пребывание в местности с жарким климатом;

- повышенную нагрузку на зрительный анализатор (долгое сидение за компьютером, у телевизора); 
- злоупотребление алкоголем;

- беременность и грудное вскармливание.

Из-за способности кумулироваться суточная доза ретинола для детей не должна превышать 900 мкг, а взрослых 3000 мкг. Прием одной лишь пищи, богатой вит. А, вряд ли способен вызвать гипервитаминоз А. Хотя в медицинской практике был описан один примечательный случай, когда группа полярных исследователей решила полакомиться печенью белого медведя. В условиях сурового климата организм этого животного приспособился накапливать вит. А в огромных количествах. А поскольку основным его депо является печень, полярники получили самое настоящее отравление ретинолом, и большая часть несчастных погибла. Но такие случаи уникальны, и не являются правилом.

В основном гипервитаминоз А развивается при передозировке синтетических ретиноидов или при их сочетании с пищей, богатой вит. А.

Основные признаки гипервитаминоза А: боль в животе, диарея, тошнота, рвота, общая слабость, гепатомегалия и спленомегалия, покраснение и зуд кожи, потливость в ночные часы, псевдожелтуха, выпадение волос, перхоть, сонливость, бессонница, кровоточивость десен, изъязвления в полости рта, болезненность и отек мягких тканей, мышечные судороги, спутанность сознания.

\section{Акушерские и перинатальные результаты дефицитарных состояний}

Витамин А является важным для деления клеток, развития органов и скелета плода, поддержания иммунной системы развития зрения у плода и здоровья глаз материи ночного видения. Таким образом, во время беременности существуют повышенные потребности вит. А, хотя необходимое дополнительное количество является небольшим, а повышенные потребности ограничены третьим триместром. Рекомендуемое потребление 
с пищей (РПП) вит. А для женщин во время беременности составляет 800 мг ретинолового эквивалента (РЭ), но в районах дефицита вит. А такого потребления достичь трудно с помощью только рациона питания. Несмотря на то что беременные женщины в гестационный период уязвимы для дефицита вит. А, недостаточность наиболее распространена в третьем триместре из-за ускоренного развития плода и физиологического увеличения объема крови в этот период. У беременных женщин с умеренной недостаточностью вит. А плод все же может получать достаточно этого компонента для нормального развития, но за счет запасов его в организме матери. Недостаточность может возникнуть также в периоды, когда распространенность инфекционных болезней является высокой, или в сезоны, когда пищевые источники, богатые вит. А, ограничены. Распространенность ночной слепоты (вследствие дефицита вит. А) также является большей в третьем триместре

Имеются некоторые свидетельства того, что добавление вит. А в низких дозах на ежедневной или еженедельной основе, начиная со второго или третьего триместра, может уменьшить остроту зрения у матерей, уровни ретинола в сыворотке в поздние сроки беременности и симптомы ночной слепоты. Одно исследование свидетельствовало о том, что для предотвращения уменьшения уровней ретинола в сыворотке необходимо проводить дотацию в течение 12 недель.

\section{Способы лабораторной диагностики}

Определение концентрации вит. А в сыворотке крови может быть использовано для оценки поступления его в организм и возникновения риска его токсичности. Однако этот показатель недостаточно хорошо отражает общие запасы вит. в печени, поскольку гомеостатически он поддерживается печенью. Уровень вит. А в крови обычно находится в пределах референсных значений, пока его запасы не становятся критически низкими (концен- 
трация менее 0,1 мкг/мл указывает на тяжелую недостаточность и истощение резерва). Содержание ретинолсвязывающего белка в крови умеренно повышается при почечной недостаточности, что может проявляться также повышением уровня вит. А.

Витамин А - пальмитат (ретинол пальмитат) - является главной формой хранения запаса вит. А в печени. В сыворотке крови его содержание в норме существенно ниже, чем основной биологически активной формы и составляет около $5 \%$ от общего содержания циркулирующего вит. А. Исследование проводят методом высокоэффективной жидкостной хроматографии - тандемной масс-спектрометрией (ВЭЖХ-МС/MC) или высокоэффективной жидкостной хроматографией с масс-селективным детектированием сыворотки крови.

Референсные значения: < 100 нг/мл.

Умеренное повышение в сыворотке эфиров ретинола (до двукратного) обычно связано с пищевыми добавками, содержащими вит. А, нередко возможно при почечной недостаточности. Ассоциация небольшого повышения с острой токсичностью маловероятна.

При остром гипервитаминозе А эфиры ретинола могут составлять более $30 \%$ от общего содержания вит. А, при тяжелой интоксикации их содержание возрастает многократно.

\section{Варианты коррекции}

Чаще всего в клинической практике используют ретинола ацетат и ретинола пальмитат. Эти медикаментозные средства выпускают в следующих лекарственных формах:

- драже- $3300 \mathrm{ME}$;

- капсулы с масляным раствором для приема внутрь $3300 \mathrm{ME}$;

- капсулы с масляным раствором для приема внутрь $5000 \mathrm{ME}$; 
- капсулы с масляным раствором для приема внутрь $33000 \mathrm{ME}$;

- таблетки, покрытые оболочкой - $33000 \mathrm{ME}$;

- раствор для наружного применения 3,44\%-ный, $100000 \mathrm{ME} /$ мл;

- инъекционный раствор 0,86\%-ный, - $25000 \mathrm{ME/мл;}$

- инъекционный раствор 1,72\%-ный, - $50000 \mathrm{ME/мл;}$

- инъекционный раствор 3,44\%-ный, - 33000 МЕ/мл.

Альтернативные формы доставки включают рыбий жир, бета-каротин и сочетание бета-каротина и вит. А. Рекомендуемые дозы препарата вит. А обычно хорошо переносятся беременными женщинами; однако вит. А может стать токсичным для матери и ее плода, если уровни потребления превышают 10000 МЕ ежедневно или 25000 еженедельно. Бета-каротин прекурсор вит. А - может быть предпочтительным по сравнению с препаратами вит. А для беременных женщин, так как излишки бета-каротина, насколько известно, не вызывают врожденных аномалий.

\section{Взаимодействие с другими веществами}

- Цинк. Способствует высвобождению вит. А из депо. Поэтому на фоне дефицита этого минерала активация будет замедленной.

- Пищевые жиры и белки. Облегчают всасывание вит. А в тонком кишечнике.

- Растительные масла, слабительные. Будучи жирорастворимым, вит. А легко растворяется в этих субстанциях и удаляется из кишечника.

- Энтеросорбенты. Также нарушают всасывание ретинола.

- Витамин Е (токоферол). Предотвращает разрушение. Поэтому дефицит вит. Е часто сопровождается дефицитом вит. А. По этой причине желательно принимать оба витамина вместе. 


\section{3. ВИТАМИН В}

Из всех вит. В 1 был идентифицирован самым первым. Можно сказать, что его открытие было предопределено исторически. Дело в том, что издавна и вплоть до середины XX в. в Индии, Китае и других странах Юго-Восточной Азии было распространено заболевание бери-бери. Эта тяжелая болезнь протекала по типу полиневрита (множественных воспалительных процессов в нервных волокнах) и зачастую заканчивалась смертью. Ученые отметили связь между бери-бери и характером питания. Местное население употребляло в пищу вареный шлифованный рис. Было высказано предположение, что в рисовой муке содержится некое токсическое вещество, которое и вызывало бери-бери. Однако впоследствии в ходе опытов на курицах выяснили, что дело вовсе не в токсичности рисовой муки. Когда птиц кормили шлифованным рисом, у них появлялись патологические изменения по типу бери-бери. Но как только в пищу подмешивали рисовые отруби, состояние птиц улучшалось. Вывод напрашивался сам собой - в рисовых отрубях содержится вещество, без которого здоровое состояние организма невозможно. В 1912 г. из рисовых отрубей выделили вещество, которое назвали амином, азотсодержащим органическим соединением. Немногим позже была разработана концепция витаминов или жизненных аминов (от лат. vita - жизнь), необходимых для поддержания жизнедеятельности. В 1936 г. была установлена химическая формула витамина, который назвали тиамином. А годом позже, в 1937 г., началось промышленное производство тиамина.

Тиамин представляет собой бесцветные кристаллы без запаха. Хорошо растворяется в воде, не растворяется в спирте. Разрушается при нагревании и в щелочной среде. Однако в кислой среде устойчив к нагреванию. Гидролизируется в воде, на открытом воздухе также нестабилен. 
Химическая формула: $\mathrm{C}_{12} \mathrm{H}_{17} \mathrm{~N}_{4} \mathrm{OS}$.

Название: 3-[(4-амино-2-метил-5-пиримидил)метил]-5-(2гидроксиэтил)-4-метил-тиазол.

Из формулы понятно, что этот витамин представляет собой серосодержащее органическое соединение. Это даже отображено в его названии: тио (сера) + амин $=$ тиамин. Среди других названий тиамина - тио-витамин, аневрин, анти бери-бери, анейрин. В этих названиях отображено действие витамина. Но их используют редко, и в основном витамин называют тиамином. Тиамин может присутствовать в свободной или фосфорилированной (в соединении с фосфорными производными) форме. Среди фосфорилированных производных тиамина: тиаминмонофосфат тиаминдифосфат тиаминтрифорсфат аденозинтиаминдифосфат аденозинтиаминтрифоссфат. Из этих соединений самым активным является тиаминдифосфат или тиаминпирофосфат, более известный как кокарбоксилаза. Это соединение является коферментом или коэнзимом (составной частью) некоторых ферментных систем, обеспечивающих важнейшие физиологические реакции. Наряду с водорастворимым вит. $\mathrm{B}_{1}$ существует его жирорастворимый аналог - бенфотиамин. По своей структуре и оказываемому физиологическому действию он сходен с тиамином.

\section{Основы метаболизма}

Пищевой и лекарственный тиамин и его производные всасываются в двенадцатиперстной кишке посредством диффузии или активного транспорта (в соединении с белком-переносчиком). Перед тем как всосаться, молекулы витамина подвергаются окислению и декарбоксилированию с образованием свободного тиамина. При этом всасывательная способность кишечника ограничена 15 мг вит. $\mathrm{B}_{1}$ в сутки. В большем количестве витамин не всасывается, а его излишек разрушается ферментом тиаминазой. Этот фермент может образовываться в организме или поступать извне. Эндогенная (внутренняя) тиаминаза образуется 
физиологической кишечной микрофлорой. Хотя его могут синтезировать и патогенные (болезнетворные) микроорганизмы стафилококки, стрептококки, протей, кишечная палочка. Вероятно, это одна из причин, почему кишечные инфекции у детей быстро приводят к снижению массы тела и замедлению роста. Экзогенная (внешняя) тиаминаза содержится в моллюсках, некоторых морских и пресноводных рыбах. Всосавшийся в кишечнике тиамин вместе с кровью поступает в печень. Здесь при участии ионов магния и под действием специфических ферментов он трансформируется в активные формы - тиаминдифосфат (кокарбоксилазу) и тиаминтрифосфат. Поэтому при дефиците магния процесс активации вит. $\mathrm{B}_{1}$ будет затруднен. Далее эти соединения с током крови разносятся по органам и тканям. При этом распределение вит. $\mathrm{B}_{1}$ неравномерное. Больше всего его содержится в скелетных мышцах - около $60 \%$. Остальные $40 \%$ поступают во внутренние органы - в сердце, печень, в почки и в головной мозг. В отличие от водорастворимых форм, жирорастворимый бенфотиамин поступает преимущественно в головной мозг. Витамин $\mathrm{B}_{1}$ не накапливается в организме, так как не растворяется в жировых тканях. Излишек витамина в неизменном виде или в виде продуктов обмена (метаболитов) полностью выводится через кишечник и через почки.

\section{Физиологические функции}

Тиамин не зря назвали витамином бодрости духа. Он позитивно влияет на эмоционально-волевую и интеллектуальную сферу: улучшает настроение, усиливает когнитивные функции память, внимание, мышление, аналитические способности, обучаемость, стимулирует мозговую деятельность, повышает стрессоустойчивость. Также этот витамин улучшает работу вестибулярного аппарата: предотвращает укачивание и улучшает координацию движений. Также вит. $\mathrm{B}_{1}$ обладает анальгезирующим (обезболивающим) действием и снижает интенсивность различ- 
ных видов боли, в том числе и зубной. Во многом эти эффекты обусловлены тем, что тиамин стимулирует образование многих жизненно важных органических соединений, среди которых: гамма-аминомасляная кислота (ГАМК) - регулирует процессы возбуждения-торможения в центральной нервной системе (ЦНС); серотонин - один из так называемых «гормонов удовольствия»; холин (вит. $\mathrm{B}_{4}$ ) - предшественник ацетилхолина, нейромедиатора, обеспечивающего передачу нервных импульсов. Но влиянием на ЦНС действие вит. $\mathrm{B}_{1}$ не ограничивается. Будучи коэнзимом, тиаминпирофосфат участвует во многих окислительно-восстановительных реакциях, поддерживает обмен жиров (липидов) и белков. В ходе этих обменных или метаболических процессов образуется энергия в виде молекул АТФ. Эта энергия затрачивается на клеточный рост и деление с передачей генетического материала от материнских клеток к дочерним.

В отношении органов и систем вит. $\mathrm{B}_{1}$ действует следующим образом:

- ЖКТ. Улучшает работу желудка и кишечника, повышает аппетит, препятствует образованию камней в системе желчевыводящих путей.

- Сердечно-сосудистая система. Повышает силу сердечных сокращений, препятствует склерозированию миокарда, улучшает кровообращение в органах и тканях.

- Костно-мышечная система. Способствует росту костей, повышает мышечную силу и выносливость.

- Система кроветворения. Стимулирует эритропоэз.

- Кожа и ее производные. Угнетает местные воспалительные процессы на коже при кожных заболеваниях (псориаз, экзема, нейродермит), ускоряет заживление ран и ожогов, замедляет процессы старения кожи.

- Иммунная система. Позитивно влияет на все звенья иммунитета, повышает сопротивляемость организма бактериальным и вирусным инфекциям.

Помимо этого, вит. $\mathrm{B}_{1}$ частично нейтрализует негативное действие алкоголя и никотина. 


\section{Содержание в продуктах, суточная потребность}

Организм человека и млекопитающих не в состоянии синтезировать тиамин, а растения могут (вит. $\mathrm{B}_{1}$ образуется в семенах, листьях, стеблях). Правда, некоторое количество тиамина синтезируется физиологической микрофлорой толстого кишечника. Но этого количества недостаточно для удовлетворения потребности в витамине. Поэтому необходимо полноценное поступление вит. $\mathrm{B}_{1}$ с пищей (табл. 5, 6).

Суточная потребность витамина $\mathrm{B}_{1}$

\begin{tabular}{|l|c|}
\hline \multicolumn{1}{|c|}{ Категория } & Норма, мг \\
\hline Младенцы до 6 мес. & 0,2 \\
\hline Младенцы 6-12 мес. & 0,3 \\
\hline Дети 1-3 лет & 0,5 \\
\hline Дети 4-8 лет & 0,6 \\
\hline Дети 9-13 лет & 0,9 \\
\hline Юноши старше 14 лет и взрослые мужчины & $1,2-2,5$ \\
\hline Девушки 14-18 лет & 1,0 \\
\hline Женщины старше 19 лет & 1,1 \\
\hline Беременные & 1,5 \\
\hline Кормящие & 1,6 \\
\hline Пожилые & $1,2-1,4$ \\
\hline
\end{tabular}

Т аблица 6

Содержание витамина $\mathrm{B}_{1}$ в пищевых продуктах

\begin{tabular}{|l|c|}
\hline \multicolumn{1}{|c|}{ Продукт } & Количество, мг/100 г \\
\hline Пивные дрожжи & $16,3-28,5$ \\
\hline Семечки & 1,95 \\
\hline Проросшие зерна пшеницы & 1,76 \\
\hline Кедровые орехи & 1,24 \\
\hline Арахис & 1,14 \\
\hline Соевые бобы & 1,1 \\
\hline Горох & 0,81 \\
\hline Горох & 0,81 \\
\hline Фасоль & 0,5 \\
\hline
\end{tabular}


Окончание табл. 6

\begin{tabular}{|l|c|}
\hline \multicolumn{1}{|c|}{ Продукт } & Количество, мг/100 г \\
\hline Свинина & 0,68 \\
\hline Говяжье сердце & 0,63 \\
\hline Овсяная крупа & 0,6 \\
\hline Отрубной хлеб из муки грубого помола & 0,54 \\
\hline Куриная печень & 0,5 \\
\hline Баранья печень & 0,41 \\
\hline Баранина & 0,36 \\
\hline Телятина & 0,23 \\
\hline Говяжья печень & $0,26-0,3$ \\
\hline Фасоль & 0,5 \\
\hline Чечевица & 0,5 \\
\hline Фундук & 0,49 \\
\hline Нешлифованный рис & 0,45 \\
\hline Кукуруза & 0,38 \\
\hline Грецкие орехи & 0,38 \\
\hline Яичный желток & 0,24 \\
\hline Картофель & 0,12 \\
\hline Брюссельская капуста & 0,1 \\
\hline Перец красный сладкий & 0,1 \\
\hline
\end{tabular}

\section{Эпидемиология}

Наиболее часто дефицит тиамина наблюдается у больных алкоголизмом - снижение его концентрации в крови отмечается у $60-80$ \% лиц данной категории.

Дефицит вит. $\mathrm{B}_{1}$ у беременных также встречается довольно часто. Например, даже в такой достаточно обеспеченной стране, как Великобритания, низкие уровни тиамина были обнаружены у 34 \% обследованных беременных.

Тиаминовая недостаточность, то есть низкий тиаминовый статус крови, является эндемичной среди ряда стран Юго-Восточной Азии: Камбоджи (70-100 \% младенцев и 27-100 \% женщин репродуктивного возраста); Лаоса (13\% новорожденных); Таиланда (16-25\% детей и $30 \%$ пожилых людей). Дефицит тиамина составляет до $45 \%$ случаев смерти детей в возрасте до 
5 лет в Камбодже, $34 \%$ случаев детской смертности в Лаосе и $17 \%$ случаев детской смертности в Мьянме. Стратегии вмешательства, которые используются для борьбы с дефицитом тиамина, включают пищевую переработку, обогащение, добавки, диверсификацию рациона питания (новолат. diversificatio «изменение, разнообразие» от лат. diversus («разный») + facere «делать»- расширение ассортимента выпускаемой продукции и переориентация рынков сбыта, освоение новых видов производств с целью повышения эффективности производства, получения экономической выгоды, предотвращения банкротства).

\section{Симптомы дефицита и избытка}

При недостаточном поступлении вит. $\mathrm{B}_{1}$ нарушается утилизация глюкозы и липидов. Формируется дефицит АТФ, накапливаются так называемые «токсины усталости» - молочная и пировиноградная кислоты. Нарушается синтез серотонина, холина, полиненасыщенных жирных кислот и других жизненно важных соединений. В результате страдают практически все системы органов. Крайняя степень авитаминоза $\mathrm{B}_{1}$ проявляется болезнью бери-бери. В переводе с индийского слово «бери» означает «ножные оковы» - у пациентов с данным заболеванием шатающаяся, заплетающаяся походка из-за полиневрита со снижением чувствительности и рассогласования движений. При крайне тяжелых формах бери-бери полиневриты приводят к полным параличам в конечностях. Помимо этого у пациентов отмечаются головная боль, головокружение, раздражительность, спутанность сознания, ухудшение памяти. Нарушается функция ЖКТ, сердечно-сосудистой системы. В прошлые времена заболевание встречалось в отдельных регионах Азии среди представителей низших социальных групп, вынужденных питаться белым шлифованным рисом и другими продуктами с низким содержанием тиамина. Патология была довольно распростра- 
ненной - болели не отдельные лица, а целые семьи и даже племена. К счастью, в настоящее время бери-бери - большая редкость. Тем не менее дефицит вит. $\mathrm{B}_{1}$ встречается и сейчас.

При этом страдают жизненно важные системы, хотя и не в такой крайней степени, как при бери-бери:

- ЦНС. Отмечается эмоциональная неустойчивость, тревожность, плаксивость. Сон нарушен. Быстрое истощение даже при незначительных умственных нагрузках. Из-за ухудшения памяти и мыслительных способностей снижается обучаемость. В старческом возрасте авитаминоз $\mathrm{B}_{1}$ - одна из причин болезни Альцгеймера.

- Периферическая нервная система. Пациенты жалуются на ощущение онемения в конечностях, преимущественно в кистях и стопах по типу «носков и перчаток». Нередко беспокоит кожный зуд.

- Сердечно-сосудистая система. Тахикардия и гипотония. При выслушивании определяется глухость сердечных тонов. Сердечная недостаточность проявляется одышкой, отеками нижних конечностей и плохой переносимостью физических нагрузок.

- ЖКТ. Боли в животе, тошнота, увеличение печени, запоры, чередующиеся с диареей. Ухудшение аппетита в сочетании с пищеварительными расстройствами приводит к потере массы тела.

У лиц, злоупотребляющих алкоголем, авитаминоз $\mathrm{B}_{1}$ может проявиться синдромом Вернике - Корсакова с тошнотой, ухудшением зрения, помутнением рассудка и нарушением координации движений из-за пареза (частичного паралича) конечностей. Но алкоголизм - далеко не единственная причина дефицита вит. $\mathrm{B}_{1}$.

К недостатку тиамина предрасполагают и другие факторы:

- прием легкоусваиваемых углеводов - макаронных, хлебобулочных и кондитерских изделий. Употребление шлифованного риса, овсяных хлопьев, белого хлеба из очищенной муки, и других «безотрубных» продуктов; 
- увлечение кофе и другими кофеинсодержащими напитками, их употребление более 2-3 чашек в день. Под действием кофеина тиамин разрушается;

- употребление морепродуктов и блюд из сырой рыбы. В этих продуктах содержится фермент тиаминаза, разрушающий тиамин, который, в свою очередь, разрушается при термической обработке, но лишь частично;

- прием блюд, прошедших термическую обработку, консервированной пищи. В процессе нагревания, стерилизации может теряться до 50 \% вит. $\mathrm{B}_{1}$, содержащегося в продуктах.

Существует ряд физиологических и патологических состояний, при которых повышается потребность в тиамине: физический труд, занятия спортом, умственные и психические нагрузки (творчество, карьера, обучение), контакт с вредными химическими соединениями, пребывание в жарком или в холодном климате, обильное потоотделение, тяжелые хронические заболевания и травмы, острые инфекционные заболевания, низкокалорийная диета, заболевания ЖКТ, прием препаратов для снижения кислотности желудочного сока, прием гормональных контрацептивов, антибиотиков, сахарный диабет, ожоги, беременность и лактация, рост и половое созревание, пожилой возраст.

Если эти состояния будут сочетаться с предрасполагающими факторами, то велика вероятность дефицита вит. $\mathrm{B}_{1}$ с соответствующими негативными симптомами. Чтобы этого не случилось, нужно обеспечить поступление вит. $\mathrm{B}_{1}$ с пищевыми продуктами или в виде лекарственных форм.

В естественных условиях гипервитаминоз $\mathrm{B}_{1}$ не развивается. Ведь тиамин всасывается в ограниченном количестве, разрушается тиаминазой и не накапливается. У пациентов с патологией печени передозировка препаратов, содержащих тиамин, может спровоцировать аллергические реакции различной тяжести вплоть до анафилактического шока. Также при регулярном длительном внутривенном введении больших доз вит. В 1 возможно нарушение функции печени и почек. Но такие случаи крайне редки. 


\section{Акушерские и перинатальные результаты дефицитарных состояний}

Витамин $\mathrm{B}_{1}$ - важнейший витамин в энергетическом обмене беременной. Особенно чувствителен к дефициту вит. $\mathrm{B}_{1}$ организм плода в III триместре беременности. Если в этот период тиамин из материнского организма будет поступать в недостаточном количестве, то у ребенка могут возникнуть серьезные нарушения со стороны ЦНС, которые приведут к задержке физического и умственного развития.

Известно, что в результате дефицита вит. $\mathrm{B}_{1}$ у беременных резко возрастают потери аминокислот с мочой. При значительном дефиците в организме женщины вит. $\mathrm{B}_{1}$ может явиться причиной неразвивающейся беременности.

В дотации вит. $\mathrm{B}_{1}$ нуждаются беременные и кормящие женщины, потребляющих в большом количестве быстроусвояемые углеводы (белый хлеб и изделия из муки высшего и 1-го сорта). При составлении рациона следует учесть, что некоторые продукты (листья черного чая, блюда из сырой рыбы (сельдь, строганина) содержат тиаминазы I и II типа, которые инактивируют вит. $\mathrm{B}_{1}$, содержащийся в организме. Эти продукты следует ограничить в рационе беременной женщины. Беременным рекомендуется зеленый чай, паровая, отварная, запеченная рыба.

Важным действующим моментом для вит. В 1 является его способность повышать секрецию молока. Витамин $\mathrm{B}_{1}$ в связи с этим используется в комплексе мер по лечению ранней гипогалактии (чаще в составе комплексных препаратов в сочетании с витаминами $\left.\mathrm{C}, \mathrm{B}_{2}, \mathrm{~B}_{6}, \mathrm{~A}\right)$.

\section{Способы лабораторной диагностики}

Уровень вит. $\mathrm{B}_{1}$ в плазме отражает преимущественно уровень его недавнего поступления в организм и в меньшей мере запасы. Для оценки статуса вит. В $_{1}$ используют исследование 
его содержания в цельной крови, эритроцитах, плазме или сыворотке. Большая часть тиамина в циркулирующей крови находится в эритроцитах и лейкоцитах (до $90 \%$ ). Тиамин плазмы составляет лишь $10 \%$ тиамина цельной крови, на его уровень в большей степени влияет недавнее потребление витамина и текущее состояние организма. Низкая концентрация $\mathrm{B}_{1}$ в плазме не всегда ассоциирована с клиническими проявлениями его нехватки - нет определенного порога, указывающего на развитие симптомов дефицита тиамина. В диагностике дефицита тиамина ведущую роль играет знание его клинических проявлений (нередко затрагивающих различные системы организма).

Уровень тиамина определяют в плазме крови методом жидкостной хроматографии с тандемной масс-спектрометрией. Референсные значения: 1,06-3,98 нг/мл.

\section{Варианты коррекции}

Лекарственные формы вит. $\mathrm{B}_{1}$ выпускаются в виде таблеток и драже для приема внутрь, а также в виде ампульного раствора для внутривенного и внутримышечного введения: тиамина хлорид, гидрохлорид - таблетки по 2; 5; 10 и 100 мг, драже 100 мг, раствор - 25 и 50 мг/мл; тиамина бромид (по активности 1,29 г тиамина бромида соответствуют 1 г тиамина хлорида) таблетки по 2,58; 6,45 и 12,9 г, раствор - 30 и 60 мг/мл; фосфотиамин (фосфорный эфир тиамина) - таблетки по 30 и 60 мг; бенфотиамин (жирорастворимый вит. $\mathrm{B}_{1}$ ) - таблетки по 5 и 25 мг, драже - 150 мг; кокарбоксилаза раствор - 50 мг/2 мл.

Взаимодействие с другими веществами. Кофеин, этиловый спирт, глюкоза, поваренная соль, танин в чае и вине - все эти пищевые ингредиенты разрушают или дезактивируют вит. $\mathrm{B}_{1}$. То же самое делают некоторые лекарства: антациды (снижающие кислотность желудочного сока), синтетические эстрогены (аналоги женских половых гормонов), антибиотики и сульфаниламиды, любые лекарственные средств на спирту или 
содержащие серу. Мочегонные препараты усиливают потерю тиамина с мочой. Некоторые противопаркинсонические средства, напротив, повышают концентрацию тиаминдифосфата в плазме крови. Под действием тиамина снижаются токсические эффекты препаратов-цитостатиков, используемых в лечении злокачественных онкозаболеваний.

Взаимоотношение вит. $\mathrm{B}_{1}$ со своими «коллегами», другими витаминами, также неоднозначно. Не рекомендован одновременный прием вит. $\mathrm{B}_{1}$ с вит. $\mathrm{B}_{6}$ (пиридоксином) и вит. $\mathrm{B}_{12}$ (цианокобаламином). Пиридоксин замедляет его активацию, а цианокобаламин способствует развитию аллергической реакции в сочетании с тиамином. Совмещать эти витамины в одном шприце нельзя, и даже в разных шприцах не рекомендуется их вводить одновременно или в течение часа. Принимать совместно тиамин с никотиновой кислотой (вит. РР или вит. $\mathrm{B}_{3}$ ) тоже нельзя, так как никотиновая кислота его разрушает.

А вот комбинация вит. $\mathrm{B}_{1}$ с вит. $\mathrm{B}_{2}$ (рибофлавином) и вит. $\mathrm{C}$ (аскорбиновой кислотой) желательна. Ведь при этом витамины взаимно активируют друг друга, а аскорбиновая кислота предотвращает окисление тиамина. Витамин $\mathrm{B}_{1}$ также снижает тяжесть проявлений дефицита вит. $\mathrm{B}_{5}$ (пантотеновой кислоты). Желательно принимать вит. $\mathrm{B}_{1}$ совместно с препаратами магния или с пищей, богатой магнием (бобовые, орехи, пшеничные отруби, курага, шпинат), так как под действием этого элемента осуществляется синтез кокарбоксилазы в печени. 


\section{4. ВИТАМИН $B_{2}$ (РИБОФЛАВИН)}

Витамин В В $_{2}$ был впервые выделен из молока еще в 1879 г. Правда, тогда действие витаминов еще не было изучено, да и самого термина «витамины» еще не существовало. Просто было установлено, что новое вещество обладает целебными свойствами. На этом все исследования и закончились вплоть до начала XX в., когда ученые разработали концепцию витаминов, жизненных аминов, азотсодержащих веществ, без которых жизнь невозможна. Первым из открытых витаминов был тиамин (вит. $\left.\mathrm{B}_{1}\right)$. Поначалу тиамин называли вит. В без всякой индексации. Данный витамин, помимо всего прочего, был неустойчив к нагреванию и быстро разрушался. Однако впоследствии было установлено, что он неоднороден, и из него была выделена термостабильная фракция. Новое вещество поначалу называли витамином GПО имени английского ученого Гольдбергера. Однако вскоре решили обозначить его как вит. $\mathrm{B}_{2}$, тем самым положив начало индексации витаминов группы В - вскоре за вит. $\mathrm{B}_{2}$ появятся вит. $\mathrm{B}_{3}, \mathrm{~B}_{4}, \mathrm{~B}_{5}$ и т.д. В 1933 г. была определена молекулярная структура нового витамина, а в 1935 г. он под названием рибофлавин был получен синтетическим путем.

Витамин $\mathrm{B}_{2}$ представляет собой кристаллическое вещество желто-оранжевого цвета, горькое на вкус, со специфическим запахом. Температура плавления кристаллов довольно высокая - около $280^{\circ}$. Этим и обусловлена термостабильность витамина. Однако к действию света риборфлавин неустойчив и под действием ультрафиолетовых лучей быстро разрушается. Также он разрушается в щелочной среде, а к кислой среде вит. $\mathrm{B}_{2}$, напротив, устойчив. Витамин $\mathrm{B}_{2}$ плохо растворяется в спирте, не растворяется в органических растворителях (ацетон, бензол, хлороформ). В воде рибофлавин также растворяется плохо, хотя его и причисляют к классу водорастворимых витаминов. 
Химическая формула вит. $\mathrm{B}_{2}: \mathrm{C}_{17} \mathrm{H}_{20} \mathrm{~N}_{406}$.

Название: 6,7-Диметил-9-(D-1-рибитил)-изоаллоксазин.

В основе молекулярной структуры лежит связь органических гетероциклических соединений с многоатомным спиртом рибитолом. Отсюда и название витамина: рибофлавин = рибитол + флавин (от лат. flavius - желтый). Так принято называть синтетический витамин $\mathrm{B}_{2}$. Но этот витамин содержится и в натуральном виде в продуктах растительного и животного происхождения. Многим из них он придает желтый окрас.

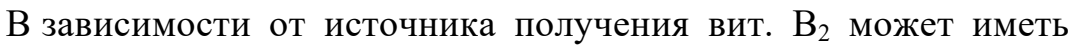
названия: из растительного сырья - вердофлавин, из печени гепатофлафин, из молока - лактофлавин, из яиц - овофлавин. Из-за способности к окрашиванию в желтый цвет он может быть использован как пищевой краситель, который обозначают как Е101. По сравнению с другими аналогичными синтетическими красителями, которые могут быть опасны для здоровья (E102, Е104), Е101 не токсичен, не вызывает аллергических реакций, и абсолютно безвреден. Также вит. В 2 легко окисляется и восстанавливается. И этой способностью предопределены его биохимические свойства и физиологическое действие на организм человека и животных

\section{Основы метаболизма}

Рибофлавин с пищевыми продуктами поступает в связанном виде, в форме флавинадениндинуклеотида (ФАД) и флавинмононуклеотида (ФМН) в комплексе с белковыми соединениями. При поступлении в ЖКТ под действием кишечных ферментов происходит его высвобождение. Далее свободный рибофлавин всасывается в тонком кишечнике, после чего в результате ферментативных процессов вновь трансформируется в ФАД и ФМН. Эти соединения током крови доставляются к органам и тканям. Их распределение неравномерное - больше всего вит. $\mathrm{B}_{2}$ поступает в печень, почки и миокард. У детей 
вит. В $_{2}$ всасывается несколько медленнее, чем у взрослых. Выделяется рибофлавин почками в неизменном виде. При тиреотоксикозе выведение вит. В $_{2}$ ускоряется, и, соответственно, его количество в организме снижается.

\section{Физиологические функции}

Активные формы рибофлавина, ФАД и рибофлавин-5фосфорная кислота, или ФМН, являются коферментами, частями ферментов, обеспечивающих многие окислительно-восстановительные реакции. Так, он наряду со своим «собратом» тиамином участвует в утилизации глюкозы с образованием молекул АТФ. Также под его действием из глюкозы образуется высокоэнергетический гликоген, который депонируется скелетными мышцами и печенью. Помимо углеводного, вит. В 2 регулирует многие виды белкового и жирового обмена. Так, при его участии из аминокислоты триптофана синтезируется ниацин (витамин РР). Кроме того, рибафлавин наделен свойствами антиоксиданта, угнетает ПОЛ (перекисное окисление липидов), предотвращает повреждение клеточных структур свободными радикалами и образование атеросклеротических бляшек на стенках сосудов. Эти процессы позитивно сказываются на состоянии органов и тканей.

- Сердечно-сосудистая система. Оказывает антиатеросклеротическое действие. Также расширяет капилляры и препятствует образованию тромбов. В результате кровоснабжение органов, в том числе и миокарда, улучшается и снижается риск ишемической болезни сердца, гипертонической болезни, кардиосклероза и инфаркта миокарда.

- Система кроветворения. Стимулирует синтез эритроцитов. Тем самым он дополнительно усиливает доставку кислорода к тканям.

- Нервная система. Улучшается кровообращение и ускоряются обменные процессы в ткани головного мозга, в результа- 
те чего снижается риск инсультов. Также повышается работоспособность, формируется хорошее настроение, нормализуется сон. Рибофлавин повышает стрессоустойчивость, устраняет негативные эмоции (депрессия, тревога, страх) и предупреждает появление психических расстройств.

- ЖКТ. Улучшает барьерные свойства слизистых оболочек желудка и кишечника, повышает их устойчивость к действию токсических соединений, патогенных (болезнетворных) бактерий и вирусов. Под действием рибофлавина усиливается образование желчи в печени и улучшается всасывание пищевых жиров в кишечнике.

- Дыхательная система. Повышает устойчивость слизистых оболочек бронхиального дерева к действию инфекции и токсических веществ.

- Костно-мышечная система. Благодаря синтезу белка и гликогена происходит рост мышц и повышается мышечная сила.

- Эндокринная система. Рибофлавин регулирует функцию щитовидной железы и надпочечников, обеспечивает синтез некоторых биологически активных веществ, в частности глюкокортикоидов (кортизол) и катехоламинов (адреналин, норадреналин).

- Органы зрения. Рибофлавин выступает как синергист ретинола (вит. А). Он повышает остроту зрения, улучшает цвето- и световосприятие, а также предупреждает помутнение роговицы, хрусталика с развитием катаракты.

- Кожа и ее производные. Повышает эластичность кожи, стимулирует рост волос и ногтей и тем самым улучшает внешний вид. Под действием вит. $\mathrm{B}_{2}$ кожа регенерирует после повреждений (раны, ожоги), замедляется старение.

- Иммунная система. Стимулирует гуморальный иммунитет - способствует образованию антител-иммуноглобулинов, тем самым повышает сопротивляемость к бактериальным и вирусным инфекциям. 


\section{Содержание в продуктах. Суточная потребность}

Согласно данным исследований, проводимых в США, если суточное поступление рибофлавина у взрослых менее 0,55 мг, то спустя 3 месяца формируется дефицит этого витамина.

Определенная часть рибофлавина синтезируется микрофлорой кишечника. Но основное количество этого витамина мы получаем вместе с пищей (табл. 7, 8).

Таблица 7

Рекомендуемые нормы потребления витамина $\mathrm{B}_{2}$

\begin{tabular}{|c|c|c|}
\hline Категория & Возраст & Норма, мг \\
\hline \multirow{2}{*}{ Грудные дети } & До 6 мес. & 0,5 \\
\hline & С 6 мес. до года & 0,6 \\
\hline \multirow{3}{*}{ Дети } & 1-3 года & 0,9 \\
\hline & 4-6 лет & 1,0 \\
\hline & $7-10$ лет & 1,4 \\
\hline \multirow{5}{*}{ Мужчины } & 11-14 лет & 1,7 \\
\hline & 15-18 лет & 1,8 \\
\hline & 18-59 лет & 1,5 \\
\hline & 60-74 года & 1,6 \\
\hline & $\begin{array}{l}\text { Старше } 75 \text { лет } \\
\end{array}$ & 1,4 \\
\hline \multirow{5}{*}{ Женщины } & 11-14 лет & 1,5 \\
\hline & 15-18 лет & 1,5 \\
\hline & 18-59 лет & 1,3 \\
\hline & 60-74 года & 1,5 \\
\hline & $\begin{array}{l}\text { Старше } 75 \text { лет } \\
\end{array}$ & 1,3 \\
\hline \multirow{2}{*}{$\begin{array}{l}\text { - беременные } \\
\text { - кормящие }\end{array}$} & - & 1,8 \\
\hline & - & 2,0 \\
\hline
\end{tabular}

Таблица 8

Содержание витамина $\mathrm{B}_{2}$ в продуктах питания

\begin{tabular}{|l|c|}
\hline \multicolumn{1}{|c|}{ Продукт } & Содержание, мг/100 г \\
\hline Пивные дрожжи & 4 \\
\hline Говяжья печень & 2,19 \\
\hline Говяжьи почки & 1,8 \\
\hline Говядина & $0,15-0,18$ \\
\hline Tелятина & 0,23 \\
\hline
\end{tabular}


Окончание табл 8

\begin{tabular}{|l|c|}
\hline \multicolumn{1}{|c|}{ Продукт } & Содержание, мг $/ 100$ г \\
\hline Свинина & $0,14-0,16$ \\
\hline Свиные почки & 1,56 \\
\hline Курица & 0,15 \\
\hline Мясо кролика & 0,18 \\
\hline Гусь & $0,23-0,26$ \\
\hline Утка & $0,17-0,43$ \\
\hline Рыба & $0,1-0,3$ \\
\hline Яйца & 0,44 \\
\hline Молоко коровье & 0,15 \\
\hline Сыр & $0,3-0,5$ \\
\hline Творог & 0,3 \\
\hline Сливочное масло & 0,1 \\
\hline Рис & 0,04 \\
\hline Крупа гречневая & 0,2 \\
\hline Пшено & 0,04 \\
\hline Фасоль & 0,18 \\
\hline Горох & 0,15 \\
\hline Соя & 0,22 \\
\hline Грецкие орехи & 0,13 \\
\hline Грибы & $0,3-0,4$ \\
\hline Шпинат & 0,25 \\
\hline
\end{tabular}

\section{Эпидемиология}

Проведенные исследования демонстрируют достаточно высокую распространенность дефицита рибофлавина, особенно у лиц молодого возраста. Причем по мере взросления частота дефицитного состояния возрастает. Например, в Великобритании у мальчиков в возрасте 4-6 лет частота дефицита $\mathrm{B}_{2}$ составляет $59 \%$, а к 10 годам достигает $78 \%$.

Наиболее подверженной дефициту $\mathrm{B}_{2}$ группой пациентов являются девочки-подростки 15-18 лет. До 95 \% девочек этого возраста имели недостаточное потребление рибофлавина и повышенный риск развития дефицита рибофлавина. Сопоставимых цифр (85-95 \%) достигает частота гиповитаминоза $\mathrm{B}_{2}$ в популяции беременных, независимо от возраста. 


\section{Симптомы дефицита и избытка}

При дефиците рибофлавина (гипо- или арибофлавинозе) нарушается углеводный, жировой и белковый обмен, активируется ПОЛ, нарушается синтез щитовидных и надпочечниковых гормонов, ухудшается всасывание железа, замедляется регенерация тканей. При этом органы и ткани претерпевают негативные изменения.

- Кожа и ее производные. Трещины в углах рта и на губах, красный язык, зудящая кожная сыпь на лице и на остальных участках тела, алопеция, выпадение волос, себорея, дерматиты, ранее старение.

- Органы зрения. Снижение остроты зрения, катаракта, склерит, конъюнктивит, сопровождающиеся болью и покраснением глаз, повышенной светочувствительностью, слезотечением, помутнением хрусталика.

- Нервная система. Тремор, головокружение, общая слабость, быстрая утомляемость, бессонница, депрессия, ухудшение мыслительных способностей, нарушение координации движений, замедление двигательных реакций.

- Мочеполовая система. Неспецифические воспалительные заболевания наружных половых органов, затруднение мочеиспускания.

- Иммунная система. Снижение защитных сил организма, частые простудные заболевания.

- Жкт. Тошнота, снижение аппетита, боли в животе, неустойчивый стул, снижение массы тела.

- Система кроветворения. Анемия и лейкопения (снижение количества лейкоцитов и эритроцитов в крови).

- Сердечно-сосудистая система. Атеросклероз, склеротические изменения и ишемия миокарда.

- Костно-мышечная система. Дистрофические изменения мышц, сопровождающиеся мышечной слабостью, интенсивными болями в нижних конечностях. У детей отмечается замедление роста и физического развития. 
Основные причины гипорибофлавиноза - болезни ЖКТ,

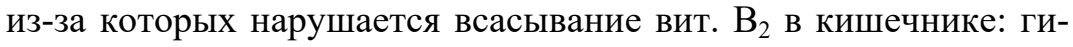
поацидный атрофический гастрит гастродуоденит язвенная болезнь желудка и двенадцатиперстной кишки, энтероколиты. Некоторые из продуктов и лекарственных препаратов также разрушают рибофлавин и снижают его активность: психотропные средства, оральные контрацептивы, акрихин и его производные, используемые в лечении малярии, алкоголь и никотин, натрия гидрокарбонат (сода), антибиотики, борная кислота, этакридина лактат (данные соединения входят в состав антисептиков, стиральных порошков, средств по уходу за кожей).

Помимо этого, существуют состояния, при которых потребность в вит. $\mathrm{B}_{2}$ повышается: физические нагрузки, занятия спортом, умственные нагрузки, психоэмоциональные стрессы, беременность и лактация, пожилой возраст, болезни щитовидной железы - гипотиреоз и тиреотоксикоз, рак, инфекционные заболевания, любые другие состояния, протекающие с лихорадкой, период полового созревания.

К арибофлавинозу предрасполагает также характер питания. Дело в том, что он лучше усваивается при заполненном желудке. Особенно благоприятно сказывается на усваивании этого витамина пища, богатая белком - мясо, молоко, творог, яйца. Соответственно, при голодании, безбелковых диетах, вегетарианстве количество вит. В 2 в организме снижается. Арибофлавиноз зачастую носит сезонный характер. Наиболее выражен он весной, когда содержание белка в мясомолочных продуктах минимально, да и самих этих продуктов до наступления лета не так уж и много.

Некоторые виды кулинарной обработки также приводят к снижению количества вит. $\mathrm{B}_{2}$ в потребляемых продуктах. Хотя рибофлавин и термоустойчив, но замораживание, длительное хранение пищевых продуктов приводит к его разрушению. Этому же способствует хранение продуктов в прозрачной упаковке (стеклянная тара, полиэтилен). Варка многих растительных про- 
дуктов улучшает усваиваемость вит. $\mathrm{B}_{2}$. Однако растворимость многих веществ, в том числе и рибофлавина, при высокой температуре повышается. Поэтому варка пищи в большом объеме воды сопровождается переходом его в варочную среду, т.е. воду, которая сливается. Напротив, если варить пищу в небольшом объеме воды с закрытой крышкой, то можно свести потери вит. $\mathrm{B}_{2}$ к минимуму. Поскольку в щелочных средах при нагревании рибофлавин разрушается, нагревание и кипячение молока также приводит к снижению количества этого витамина. В силу всех этих причин (заболевания, изменения характера питания, неправильная кулинарная обработка) гипорибофлавиноз - довольно распространенное явление. В той или иной степени им страдает до 80-90 \% населения.

Подобно многим другим витаминам группы В, рибофлавин не накапливается в организме. Поэтому гипервитаминоз $\mathrm{B}_{2}$ в естественных условиях не возникает. Передозировать его тоже сложно. Иногда, при введении больших доз и нарушении выделительной функции почек, возможна головная боль, головокружение, парестезии (жжение, онемение, покалывание) в конечностях, окрашивание мочи в насыщенный желтый цвет.

\section{Акушерские и перинатальные результаты дефицитных состояний}

Одной из групп высокого риска развития дефицита рибофлавина являются женщины во время беременности, когда потребность в рибофлавине увеличивается. Дефицит рибофлавина может сказаться не только на матери, но и на ее ребенке.

При дефиците рибофлавина в три раза возрастает риск развития: дефектов конечностей плода, врожденных пороков сердца, преэклампсии и расщелины нёба у плода, послеродовой депрессии.

B 1943 г. Burke et al. сообщили о возможной связи между питанием женщины и ее беременностью. Исследования на животных показали, что тяжелый дефицит рибофлавина у бере- 
менных мышей и цыплят приводит к аномальному развитию плода и спонтанному прерыванию беременности. Большинство исследований, документирующих дефицит рибофлавина у людей, проводились в обществах с низким потреблением рибофлавина. Исследования показали, что риск дефицита рибофлавина у беременных особенно высок в третьем триместре беременности, при приближении родов и в период лактации. Во время беременности метаболические потребности возрастают, в среднем до 230 ккал в день, что для большинства женщин составляет более $10 \%$ от их общего суточного потребления ккал. В первые два триместра преобладает анаболизм, повышается чувствительность к инсулину, увеличиваются жировые отложения матери. В начале третьего триместра плацентарные гормоны вызывают повышение инсулинорезистентности и катаболизма у матери, что обеспечивает питательные вещества для роста плода, а также возрастающую потребность в богатых энергией питательных веществах, таких как жирные кислоты и витамины, в том числе рибофлавин, для обеспечения митохондриального энергетического метаболизма.

Во время родов рибофлавин обладает важной антиоксидантной функцией, основанной на том, что ФАД является важным кофактором глутатиона. Глутатион имеет решающее значение для противодействия реакциям перекисного окисления, вызванным быстрым переходом от гипоксической к гипероксической среде во время родов.

Рибофлавин важен и в послеродовом периоде. Исследования показали, что фотототерапия, которая часто используется для лечения гипербилирубинемии у детей вскоре после рождения, может вызвать дефицит рибофлавина и снижает уровень рибофлавина до 50 \% в течение нескольких часов. Кроме того, материнское питание и рибофлавиновый статус имеют большое значение во время грудного вскармливания. Для детей, находящихся исключительно на грудном вскармливании, материнское молоко является единственным источником рибофлавина. Ри- 
бофлавин в основном присутствует в виде ФАД в молоке человека, а дефицит рибофлавина у матери быстро отражается в низкой концентрации флавина в молоке. Грудное вскармливание ребенка имеет огромное значение для обеспечения потребности в питательных веществах, а также для развития иммунного ответа ребенка.

\section{Способы лабораторной диагностики}

Уровень рибофлавина определяют в плазме крови методом жидкостной хроматографии с тандемной масс-спектрометрией. Референсные значения: 40-240 нг/мл. Пределы токсичности рибофлавина не установлены.

\section{Варианты коррекции}

Синтетический рибофлавин выпускается в виде различных лекарственных форм: порошок для приема внутрь, драже 2 мг, таблетки по 2; 5 и 10 мг, 1\%-ный ампульный раствор для внутримышечного и внутривенного введения, 0,01\%-ные глазные капли. Помимо основного названия, препарат может также выпускаться под другими наименованиями: рибофлавинмононуклеотид, рибофлавин-5-фосфат натрия, рибофлавин натрия фосфат.

Среди зарубежных препаратов: Riboflavin High Flow 100 немецкого производства и выпускаемые в США капсулы Solgar, Now Foods, Nature's Way с содержанием 100 мг рибофлавина. Также он включен в состав комплексных препаратов, среди которых «Тиамин. Рибофлавин. Пиридоксин» $\left(\mathrm{B}_{1}, \mathrm{~B}_{2}, \mathrm{~B}_{6}\right)$, «Солувит», «Спектрум» и многих других. Наряду с этим рибофлавин присутствует во многих БАД и гомеопатических средствах.

Как и пищевые продукты, богатые вит. $\mathrm{B}_{2}$, препараты рибофлавина для приема внутрь (таблетки, драже, капсулы) жела- 
тельно принимать во время еды - так витамин лучше усваивается. При МКБ (мочекаменной болезни) прием препаратов рибофлавина противопоказан.

Взаимодействие с другими веществами и препаратами. Витамин $\mathrm{B}_{2}$ способствует переходу пиридоксина (вит. $\mathrm{B}_{6}$ ) в активную форму, поэтому желателен совместный прием этих витаминов. Также имеются данные, что рибофлавин, вит. К и фолиевая кислота взаимно потенцируют действие друг друга. При участии вит. $\mathrm{B}_{2}$ происходит образование ниацина (вит. $\mathrm{B}_{3}$, вит. РР, никотиновая кислота). Комплексно с никотиновой кислотой рибофлавин стимулирует детоксикацию. Под действием вит. $\mathrm{B}_{2}$ повышается биодоступность цинка. Также он повышает содержание в организме железа и усиливает его действие. Антибиотики эритромицин и тетрациклин усиливают выведение вит. $\mathrm{B}_{2}$ с мочой. В свою очередь он снижает эффективность многих антибиотиков. Со стрептомицином рибофлавин несовместим. Снижает побочные действия хлорамфеникола, антибиотика широкого спектра действия. Психотропные средства (нейролептики, транквилизаторы) замедляют его трансформацию в активные формы. Борная кислота разрушает рибофлавин. М-холинолитики (платифиллин, атропин, скополамин) улучшают всасывание витамина в кишечнике. Синтетические гормоны щитовидной железы ускоряют выведение из организма. 


\section{5. ВИТАМИН В 3 (РР, НИАЦИН, НИКОТИНОВАЯ КИСЛОТА, НИКОТИНАМИД)}

Никотиновая кислота (Acidum Nicotinicum) - это представитель класса водорастворимых витаминов (также известная как ниацин, вит. РР, вит. В $_{3}$ ). Белый кристаллический порошок без запаха, со слабокислым вкусом. Плохо растворяется в холодной воде, лучше - в горячей; мало растворим в этиловом спирте; очень мало - в эфире.

Никотиновая кислота впервые была синтезирована путем окисления никотина ученым Хубером в 1867 г. Современное название она получила в 1873 г., когда Вайдел получил это вещество, окислив никотин азотной кислотой. Однако о витаминных свойствах никотиновой кислоты еще ничего не было известно. В 1915 г. американский врач Джозеф Голдбергер провел серию экспериментов на 11 здоровых добровольцах, заключенных в тюрьму в Миссисипи, и обнаружил, что может вызвать пеллагру, изменяя их рацион. Он пришел к выводу, что это заболевание вызвано отсутствием определенного фактора, который отсутствует в кукурузе, но присутствует в мясе и молоке. Он назвал его фактором РP (pellagra-preventative). Химическая структура этого фактора была открыта в 1937 г. американским биохимиком Конрадом Арнольдом Элвехьемом. Он вызывал развитие черного языка у собак, кормя их диетой Голдбергера, а затем лечил болезнь назначением никотиновой кислоты. Он также изолировал фактор РР из активных экстрактов печени, показав, что этот фактор фактически является никотиновой кислотой. В 1938 г. в СССР уже успешно лечили пеллагру никотиновой кислотой. О влиянии никотиновой кислоты на липидный обмен стало известно в середине XX в. Современные лабораторные и промышленные методы синтеза никотиновой кислоты основаны также на окислении производных пиридина. 
Никотиновая кислота относится к производным пиридина с химической формулой $\mathrm{C}_{6} \mathrm{H}_{5} \mathrm{NO}_{2}$ и номенклатурным названием бета-пиридинкарбоновая кислота.

Внешне выглядит как бесцветные кристаллы игольчатой формы без запаха, но со слабым кислым вкусом. Устойчива к нагреванию и действию солнечного света. Растворяется в воде, причем в горячей растворимость намного выше, чем в холодной. Плохо растворяется в этиловом спирте, практически не растворяется в эфире. Хорошо взаимодействует со многими кислотами и щелочами, образуя при этом соли никотиновой кислоты - никотинаты.

Примечательно, что вит. В 3 может существовать не только в виде никотиновой кислоты, но и в виде ее амидного производного, никотинамида с химической формулой $\mathrm{C}_{6} \mathrm{H}_{6} \mathrm{~N}_{2} \mathrm{O}$. По химическому строению, физическим свойствам и биологическому действию никотинамид сходен с никотиновой кислотой. В тканях вит. РР присутствует в виде никотинамида, который трансформируется из никотиновой кислоты. Никотинамид представлен многими лекарственными формами. Здесь его применение более предпочтительно, так как в сравнении с никотиновой кислотой он легче переносится. До недавнего времени ниацин использовали в пищевой промышленности в виде добавки Е375. Однако с 2008 г. применение E375 на территории Российской Федерации было запрещено.

\section{Основы метаболизма}

Никотиновая кислота в нормальных физиологических условиях является компонентом коферментов НАД и НАДФ, которые необходимы для окислительно-восстановительных реакций в тканевом дыхании. Никотинамид обладает аналогичными функциями как витамин, но не имеет фармакологического значения в снижении уровня липидов. О липидо-модифицирующих эффектах никотиновой кислоты впервые были сообщено в 1955 г., 
когда было отмечено, что она снижает уровень общего холестерина и холестерина липопротеинов низкой плотности (Х-ЛПНП), повышает уровень холестерина липопротеинов высокой плотности (Х-ЛПВП). Более поздние исследования подтвердили эти первоначальные выводы, а также показали дифференциальное дозозависимое влияние никотиновой кислоты на уровни Х-ЛПНП и Х-ЛПВП. В то время как вызванные никотиновой кислотой изменения уровня Х-ЛПВП - логарифмические, изменения уровня Х-ЛПНП - линейные. В результате этого относительно небольшие дозы никотиновой кислоты (1,5-2,0 г в день) вызывают значительное увеличение Х-ЛПВП (примерно на 15-40 \%), что делает ее наиболее эффективным препаратом для повышения уровня Х-ЛПВП. Наоборот, для снижения уровня Х-ЛПНП примерно на 15 \% необходимы дозы 3,0-4,5 г/сут никотиновой кислоты. Кроме этого, никотиновая кислота показала снижение уровня триглицеридов в сыворотке крови на 20-50\% и липопротеина (а) - примерно на 20 \%. Влияние на триглицериды клинически полезно, учитывая все большее количество доказательств вовлечения богатых триглицеридами липопротеинов в атерогенез, но значение снижения липопротеина (а) остается неясным. Никотиновая кислота снижает уровень Х-ЛПНП в плазме крови через несколько механизмов. Она подавляет периферическую мобилизацию свободных жирных кислот, что уменьшает количество субстрата, доступного для печеночного синтеза триглицеридов и частиц липопротеинов очень низкой плотности (Х-ЛПОНП). Это, в свою очередь, снижает печеночное преобразование частиц Х-ЛПОНП в частицы Х-ЛПНП. Кроме того, никотиновая кислота непосредственно влияет на ферментативный процесс, который опосредует превращение Х-ЛПОНП в Х-ЛПНП и снижает синтез триглицеридов и печеночную секрецию липопротеинов с помощью ингибирования диацилглицеролацетилтрансферазы-2. Влияние никотиновой кислоты на уровни $\mathrm{X}$-ЛПВП частично опосредовано снижением уровней Х-ЛПНП и Х-ЛПОНП, так как снижение доступности этих липопротеи- 
нов ограничивает перенос холестерина из Х-ЛПВП в Х-ЛПНП и Х-ЛПОНП, тем самым увеличивая уровни Х-ЛПВП в плазме крови. Тем не менее этот механизм не может полностью объяснить существенное влияние никотиновой кислоты на уровни Х-ЛПВП. Исследования на мышиных и человеческих моделях выявили несколько других новых механизмов, которые действуют параллельно. Во-первых, никотиновая кислота снижает концентрацию и активность белка-переносчика эфиров холестерина - фермента, который переносит холестерин из частиц ЛПВП к частицам ЛПНП и ЛПОНП. Результатом этого является сохранение частиц ЛПВП за счет частиц ЛПНП и ЛПОНП. Во-вторых, никотиновая кислота селективно снижает печеночную экскрецию аполипопротеина А-I - основного белкового компонента Х-ЛПВП - вероятно, за счет ингибирования на поверхности гепатоцитов экспрессии $\beta$-цепи аденозинтрифосфатсинтазы, недавно описанного рецептора комплекса ЛПВП-аполипопротеин A-I. Это позволяет большему количеству Х-ЛПВП, содержащих полипопротеин A-I, вернуться в циркуляцию из печени. В дополнение к повышению уровней Х-ЛПВП, никотиновая кислота, кажется, непосредственно действует на атеросклеротическую бляшку, содействуя оттоку холестерина из макрофагов артериальной стенки - процесс, известный как обратный транспорт холестерина.

\section{Физиологические функции}

В значительной степени физиологическая роль вит. РР обусловлена тем, что он входит в состав НАД (никотинамидадениндинуклеотид) и НАДФ (никотинамидадениндинуклеотидфосфат). Это основные коферменты или кофакторы (элементы, составные части) многих ферментных систем. Поэтому влияние ниацина на состояние организма многообразно. Этот витамин участвует во всех видах обмена веществ: обеспечивает синтез азотистых соединений, пуринов и пиримидинов, регулирует 
гликогенолиз, участвует в биосинтезе белка, регулирует количество и баланс аминокислот, нормализует количество и соотношение различных типов липидов, участвует в тканевом дыхании, обеспечивает течение многих других окислительно-восстановительных реакций.

Со стороны органов и систем его действие проявляется следующим образом.

- Сердечно-сосудистая система. Снижает уровень Х-ЛПНП и повышает уровень Х-ЛПВП, благодаря чему предотвращает развитие атеросклероза. Расширяет кровеносные сосуды и тем самым снижает артериальное давление (АД) и улучшает кровообращение в органах и тканях. Предотвращает развитие инфаркта миокарда, а у перенесших инфаркт уменьшает риск фатальных осложнений.

- Система кроветворения. Стимулирует образование эритроцитов и гемоглобина, в некоторой степени угнетает коагуляцию крови. Снижает вязкость крови и предотвращает патологическое тромбообразование и дополнительно улучшает тканевое кровообращение.

- Нервная система. Активизирует кору больших полушарий и другие структуры ЦНС. Стимулирует синтез серотонина. Благодаря этому улучшается мышление, внимание, память. Человек испытывает позитивные эмоции. Вместе с тем под действием ниацина в ЦНС генерируются тормозные импульсы. В результате устраняется депрессия, страх, тревога. Именно по этой причине вит. $\mathrm{B}_{3}$ называют витамином спокойствия. Он оказывает позитивное действие при различных невротических и психотических расстройствах, в том числе и при шизофрении. Эффективен он и при мигрени. Благодаря улучшению кровообращения в ЦНС снижается риск развития инсультов.

- ЖКТ. Симулирует моторику желудка и кишечника. Усиливает секрецию желудочного сока и повышает его кислотность. Улучшает функцию поджелудочной железы и печени. В результате повышается качество переваривания пищи. 
- Иммунная система. Стимулирует лейкоцитарный фагоцитоз и тем самым укрепляет иммунитет, предотвращает развитие инфекционных заболеваний. При уже начавшихся заболеваниях снижает тяжесть воспалительных процессов.

- Эндокринная система. Стимулирует функцию многих желез внутренней секреции. Под действием никотиновой кислоты усиливается продукция соматотропного гормона (гормона роста) передней долей гипофиза (аденогипофизом). Количество других тропных гормонов аденогипофиза также увеличивается. Повышается синтез гормонов щитовидной железы, надпочечников, тестостерона и эстрогенов. Объем инсулина, выделяемого поджелудочной железой, также увеличивается. Снижается уровень глюкозы в крови, предупреждается развитие сахарного диабета.

- Дыхательная система. Повышает содержание надпочечниковых гормонов-глюкокортикоидов, расширяет бронхиальный просвет, делает внешнее дыхание более эффективным, препятствует развитию приступов бронхиальной астмы и других состояний, сопровождающихся спазмом бронхов.

- Кожа и ее производные. Повышает прочность и эластичность кожи, препятствует появлению патологических высыпаний на коже и слизистых оболочках. Стимулирует рост волос.

- Костно-мышечная система. Благодаря синтезу соматотропного гормона оказывает анаболическое действие (стимулирует синтез белка), тем самым повышает мышечную силу и выносливость. При суставных заболеваниях (остеоартрозах) ниацин уменьшает боль и расширяет объем движений. Наряду с этим никотиновая кислота препятствует развитию аллергических реакций и способствует удалению из организма токсичных соединений. Эффективен при устранении алкогольной зависимости. Несмотря на созвучное с никотином название, тягу к курению никотиновая кислота тоже снижает. 


\section{Содержание в продуктах, суточные нормативы потребления}

Поскольку никотиновая кислота образуется из никотина, можно предположить, что курение способствует увеличению количества этого витамина. Однако получить вит. $\mathrm{B}_{3}$ таким способом можно лишь химическим путем. В организме человека нет ферментов, обеспечивающих трансформацию никотина в никотиновую кислоту. Этот витамин образуется из аминокислоты триптофана при участии бактериальной флоры. Довольно много триптофана содержится в животной пище - мясе, рыбе, твороге, молоке, яйцах. Растительные продукты, богатые триптофаном грибы, орехи, бобовые, шоколад. Однако самостоятельно удовлетворить потребность организма в вит. В3 организм не в состоянии. Ведь на синтез 1 мг вит. РР расходуется 60 мг триптофана. Данное соотношение именуют ниациновым эквивалентом. Чтобы избежать авитаминоза РР, нужно в достаточном количестве принимать его с пищей. Поэтому прием продуктов, содержащих ниацин, жизненно необходим (табл. 9, 10).

Т а блица 9

Рекомендуемые нормы потребления никотиновой кислоты

\begin{tabular}{|l|c|}
\hline \multicolumn{1}{|c|}{ Категория } & Суточная норма, мг \\
\hline Дети от 6 мес. до года & 6 \\
\hline Дети 1-1,5 лет & 9 \\
\hline Дети 1,5-2 лет & 10 \\
\hline Дети 3-4 лет & 12 \\
\hline Дети 5-6 лет & 13 \\
\hline Дети 7-10 лет & 15 \\
\hline Дети 11-13 лет & 19 \\
\hline Девушки 14-17 лет & 18 \\
\hline Юноши 14-17 лет & 21 \\
\hline Взрослые мужчины и женщины & $18-25$ \\
\hline Беременные & $22-26$ \\
\hline Кормящие & $24-28$ \\
\hline
\end{tabular}


Количество никотиновой кислоты в продуктах питания

\begin{tabular}{|l|c|}
\hline \multicolumn{1}{|c|}{ Продукт } & $\begin{array}{c}\text { Содержание витамина РР, } \\
\text { мг/100 г }\end{array}$ \\
\hline Дрожжи & 11,4 \\
\hline Говядина & 4,7 \\
\hline Говяжья печень & 9 \\
\hline Говяжье сердце и почки & 3,7 \\
\hline Говяжьи мозги & 3 \\
\hline Мясо кролика & 6,2 \\
\hline Мясо кур & 7,8 \\
\hline Баранина & 3,8 \\
\hline Свинина & 2,2 \\
\hline Крупа гречневая, зерновой пшеничный хлеб & $4-4,19$ \\
\hline Крупа ячневая, кальмары & 2,54 \\
\hline Крупа манная и овсяная & 1,2 \\
\hline Треска & 2,3 \\
\hline Печень трески & 1,79 \\
\hline Зеленый горошек, фундук & 2 \\
\hline Белые грибы & 5 \\
\hline Ставрида & 1,3 \\
\hline Морковь, красный сладкий перец, грецкие орехи & 1 \\
\hline Помидоры, сливочное масло & $0,5-0,53$ \\
\hline Томатная паста & 1,9 \\
\hline Белокочанная капуста & 0,7 \\
\hline Творог, яблоки & 0,3 \\
\hline
\end{tabular}

\section{Симптомы дефицита и избытка}

Основная причина дефицита вит. $\mathrm{B}_{3}$ - это его недостаточное поступление с пищей. Если в потребляемой пище содержится малое количество триптофана, это тоже приведет к недостатку никотиновой кислоты, так как триптофан - это биологическое сырье для ниацина. Эта аминокислота является незаменимой, т.е. в организме она не образуется, а поступает только извне. В сутки необходим 1 г триптофана. Это количество идет не только на синтез ниацина бактериальной флорой кишечника, но и на другие физио- 
логические нужды. Поэтому недостаток пищевого триптофана автоматически влечет снижение количества никотиновой кислоты. Воспалительные заболевания ЖКТ также приведут к этому состоянию. Кишечная патология, как правило, сопровождается дисбактериозом, а при угнетении физиологической кишечной флоры синтез эндогенного (внутреннего) ниацина тоже будет нарушен.

Образование никотиновой кислоты из триптофана происходит при участии ряда витаминов и минералов - вит. $\mathrm{B}_{2}, \mathrm{~B}_{6}$, меди. Поэтому при недостатке этих веществ будет развиваться дефицит никотиновой кислоты.

Помимо этого, существует ряд факторов, способствующих усиленному расходу или разрушению витамина РР и, соответственно, его дефициту: физические нагрузки, психоэмоциональные стрессы, проживание в регионах с холодным или, напротив, жарким климатом, работа при высокой температуре, в горячих цехах, беременность, грудное вскармливание, преобладание в пищевом рационе растительной пищи, недостаточное потребление животных белков, злоупотребление алкоголем, прием сладких блюд и напитков с большим количеством сахара, прием некоторых лекарств.

Подобно другим витаминам дефицит никотиновой кислоты может быть относительным (гиповитаминоз) и абсолютным (авитаминоз). Типичное проявление авитаминоза РP - пеллагра. Данное заболевание проявляется триадой Д: диарея, деменция, дерматит. Болезнь протекает крайне тяжело и в отсутствие лечения заканчивается фатально. Поэтому в английской транскрипции, наряду с этими тремя, есть и четвертая Д - Death, смерть.

Болезнь была распространена в регионах, где в пищевом рационе преобладала кукуруза, продукт с низким содержанием ниацина и триптофана. Сходные с пеллагрой симптомы довольно часто отмечаются у лиц с хроническим алкоголизмом. В последние десятилетия пеллагра - довольно редкое явление, а дети не болеют даже в слабо развитых регионах. Тем не менее признаки гиповитаминоза можно встретить и сейчас, причем повсеместно. Только в России в течение каждого года выявляют 
несколько тысяч пациентов с заболеваниями, в той или иной мере обусловленными гиповитаминозом РР.

Основные признаки гиповитаминоза РР: общая слабость, быстрая утомляемость, головная боль, головокружение, ощущение шума или звона в ушах, кратковременные обморочные состояния, бледность и сухость кожи, повышенная чувствительность кожи к солнечному свету (фотодерматоз), дерматиты, сопровождающиеся зудом и сыпью, воспаление десен и языка, кровоточивость десен, ощущение жжения в полости рта, отечность и трещины на губах, выпадение волос, облысение, тошнота, рвота, снижение аппетита, боли и вздутие живота, воспалительные процессы в желудке и кишечнике, диарея, психические расстройства: депрессии, раздражительность, расстройства сна, раннее прогрессирующее слабоумие, неврологические расстройства: невриты, сопровождающиеся болями и парестезиями в конечностях, параличи, анемия, снижение либидо, бесплодие; у мужчин - эректильная дисфункция, у женщин - нарушения менструального цикла, мышечная слабость, мышечные и суставные боли. Дефицит вит. РР - одна из причин развития таких тяжелых заболеваний, как гипертоническая болезнь, ишемическая болезнь сердца со стенокардией и инфарктом миокарда, псориаз, сахарный диабет, мозговые инсульты, болезнь Альцгеймера, потемнение кожи на коленях. Однако гиповитаминоз вит. РР может длительное время протекать латентно, без характерных клинических проявлений.

РР-гиповитаминоз обычно развивается в связи с нарушением всасывания витамина при воспалительно-дистрофических заболеваниях тонкой кишки. Иногда признаки гиповитаминоза появляются на относительно ранних стадиях развития энтерита, протекающего с синдромом мальабсорбции, или при болезни Крона.

Типичным побочным действием высоких доз витамина является выраженное, но непродолжительное сосудорасширяющее действие с покраснением лица, головокружением, снижением АД и тахикрадией. При длительном применении препаратов 
никотиновой кислоты в относительно больших дозах может развиться жировая дистрофия печени. Возможны аллергические реакции с анафилактическим шоком, астматическими приступами, крапивницей. Препараты никотиновой кислоты не показаны при хроническом гепатите, циррозе печени, язвенной болезни желудка и двенадцатиперстной кишки, сахарном диабете, подагре.

\section{Акушерские и перинатальные результаты дефицитарных состояний}

Коферментная форма вит. РР - никотинамид, не влияет на выделение гистамина тучными клетками и используется вместо никотиновой кислоты в поливитаминных комплексах для беременных и кормящих женщин.

Низкие диетарные уровни рибофлавина (менее 1-2 мг/сут) и ниацина (менее 13,5 мг/сут) в два раза увеличивают риск рождения ребенка с врожденными пороками сердца. Увеличение дотации никотинамида уменьшало риск развития пороков независимо от диетарного потребления фолатов. Уровни потребления тиамина, пиридоксина и ниацина в преконцепции были гораздо ниже у матерей, родивших детей с расщелиной нёба, чем у родивших детей без этого дефекта развития. Никотинамид принимает участие в биосинтезе НАД и НАДФ - широкоизвестных кофакторов энергетического метаболизма, поэтому дефекты в соответствующих генах метаболизма также увеличивают риск врожденных пороков, особенно при пищевом дефиците витамина. Экспериментальные исследования показали, что никотинамид предотвращает гипоксию плода.

\section{Способы лабораторной диагностики}

Уровень рибофлавина определяют в плазме крови методом жидкостной хроматографии с масс-селективным детектированием. Референсные значения составляют 5,2-72,1 нг/мл. 


\section{Варианты коррекции}

Никотиновая кислота представлена следующими лекарственными формами: порошок для приема внутрь таблетки 50 мг, драже - 5 и 15 мг, 1\%-ный ампульный раствор для внутримышечного и внутривенного введения. Формы выпуска никотинамида: порошок для приема внутрь, таблетки - 5 и 25 мг, $1 \% ; 2,5 \%$-ный и 5\%-ный ампульный раствор для внутримышечного и внутривенного введения. Никотиновая кислота и ее производные входят в состав таких препаратов, как ниацин, апеларгин, эндурацин, никонацин, натрия никотинат и ксантинола никотинат, а также никоверин и паниверин (в комбинации с папаверином).

Никотиновая кислота как субстанция для препаратов дешевле, чем никотинамид, и поэтому именно она часто входит в состав БАД.

Не существует сообщений о неблагоприятном влиянии никотиновой кислоты на плод человека.

Никотиновая кислота проникает в грудное молоко. Следует прекратить прием препарата при кормлении грудью или прекратить кормление.

\section{Взаимодействие с другими препаратами}

- Адреноблокаторы. Из-за дополнительного сосудорасширяющего влияния может возникнуть постуральная гипотензия.

- Антигипергликемическая терапия. Из-за того, что никотиновая кислота может вызвать гипергликемию, может понадобиться коррекция дозы инсулина или пероральных антигипергликемических препаратов у пациентов с сахарным диабетом.

- Аспирин. Одновременное использование аспирина и никотиновой кислоты может привести к снижению покраснения кожи и чувства жара, связанными с приемом никотиновой кислоты. Также одновременное применение аспирина может привести 
к повышению и продлению концентрации никотиновой кислоты, поэтому может существовать опасность ее токсичного действия.

- Клонидин (клофелин). Одновременное употребление никотиновой кислоты и клонидина приводит к уменьшению покраснения кожи после ее приема.

- Колестипол. Абсорбция никотиновой кислоты может зависеть от приема колестипола. Комбинированное использование этих двух препаратов приводит к большему снижению концентрации холестерина в плазме, чем использование только колестипола.

- Глизипид. Совместное применение глизипида и никотиновой кислоты может привести к потере контроля над уровнем глюкозы в крови, так как никотиновая кислота может вызвать гипергликемию.

- Изониазид. Совместное использование изониазида и никотиновой кислоты может привести к повышению потребности в никотиновой кислоте, но пеллагра развивается редко, только у пациентов с предшествующим дефицитом никотиновой кислоты.

- Статины (ловастатин, правастатин, симвастатин). Одновременное использование статинов и никотиновой кислоты может быть связано с миопатией и повышением риска развития рабдомиолиза и острой почечной недостаточности. Должны контролироваться симптомы миопатии и рабдомиолиза.

- Никотин. Если никотиновая кислота и трансдермальный никотин используются одновременно, могут возникнуть покраснение кожи и головокружение после приема никотиновой кислоты.

- Алкоголь. Сообщается о том, что одновременное употребление алкоголя и никотиновой кислоты может привести к делирию и лактат-ацидозу.

- Аллопуринол. Прием высоких доз никотиновой кислоты могут привести к снижению эффективности аллопуринола.

- Карбамазепин. Есть опасения, что никотиновая кислота может замедлять распад карбамазепина, но нет данных о значимости этого процесса. 


\section{6. ВИТАМИН В 6 (ПИРИДОКСИН)}

Витамин В 6 (Пиридоксин) - один из представителей водорастворимых витаминов группы В. Его еще называют универсальным стимулятором метаболизма (обмена веществ). Все важнейшие биохимические реакции в нашем организме проходят с его участием, а недостаток этого витамина отрицательно сказывается на состоянии всех органов и систем.

В первой половине прошлого века было установлено, что в основе многих заболеваний лежит дефицит определенных веществ. Среди этих заболеваний - пеллагра, которая ранее ошибочно считалась инфекционным заболеванием. Пеллагра проявлялась тяжелыми психоневрологическими расстройствами, патологическими изменениями на коже и в ЖКТ и нередко приводила к гибели. Как только была определена связь пеллагры с авитаминозом, сразу же начался поиск соответствующего витамина. В опытах на крысах было установлено, что вит. В (тиамин) и вит. $\mathrm{B}_{2}$ (рибофлавин) не устраняют пеллагру. Однако скармливание подопытным животным дрожжей приводило к регрессированию симптомов пеллагры и к улучшению самочувствия. Ученые справедливо предположили, что в дрожжах содержится некое вещество, которое оказывает антипелларгическое действие. Это вещество назвали крысиным фактором. В 1934-1939 гг. данное вещество в натуральном виде выделили из дрожжей и рисовых отрубей, была установлена его структурная формула, а затем его получили синтетическим путем. Новый витамин назвали пиридоксином. Примечательно, что пиридоксин неэффективен при лечении пеллагры, для ее лечения используется вит. РР (никотиновая кислота), который также содержится в дрожжах. Тем не менее пиридоксин участвует во многих других обменных и физиологических процессах, что вскоре и было установлено. Немногим позже, в 1944 г., были 
выделены еще две разновидности вит. $\mathrm{B}_{6}$, пиридоксаль и пиридоксамин, и определены их структурные формулы.

Пиридоксин (пиридоксол) представляет собой бесцветный кристаллический порошок. Кристаллы не издают запаха, но имеют горько-кислый вкус. Пиридоксин хорошо растворяется в воде и в спирте, но не растворяется в жировых субстанциях и в эфире. Устойчив к нагреванию и к действию атмосферного кислорода. Однако разрушается на свету.

Химическая формула пиридоксина: $\mathrm{C}_{8} \mathrm{H}_{11} \mathrm{NO}_{3}$.

Название: 5-Гидрокси-6-метил-3,4-пиридиндиметанол (и в виде гидрохлорида).

Наряду с пиридоксином (пиридоксолом) вит. В 6 включает в себя пиридоксамин и пиридоксаль. Эти вещества со сходной химической структурой, физическими свойствами и действием на организм человека называют витамерами. Они образуются из пиридоксина и тоже обладают свойствами витаминов. Пиридоксаль является альдегидным аналогом пиридоксина. Трансформация пиридоксина в пиридоксаль происходит при его взаимодействии с аммиаком, перманганатом калия и другими окислителями. Взаимодействие пиридоксаля с глутаминовой кислотой и рядом аминокислот приводит к образованию пиридоксамина аминного производного пиридоксина. Пиридоксамин и пиридоксаль могут взаимно превращаться друг в друга в ходе химических реакций - переаминирования, катализируемых специфическими ферментами.

Естественная комбинация пиридоксаля и пиридоксамина получила название псевдопиридоксина. Данное вещество выделено из мочи животных, и ему присущи все свойства вит. $\mathrm{B}_{6}$. Витаминной активностью обладают не сами витамеры, а их фосфорные производные. Из пиридоксаля и пиридоксамина в ходе ферментативных реакций образуются фосфаты - пиридоксаль-5-фосфат и пиридоксамин-5-фосфат. Эти соединения не что иное, как активные формы витамина $\mathrm{B}_{6}$, которые формируют его свойства. Биологическая активность пиридоксальфос- 
фата в сравнении с пиридоксаминфосфатом намного выше. Но несмотря на то что витамин $\mathrm{B}_{6}$ представлен несколькими витамерами и их фосфатами, за ним закрепилось название пиридоксин. В некоторых источниках этот витамин называют адермином или фактором Ү. Но эти названия встречаются редко. Наряду с естественными витамерами учеными были получены многочисленные синтетические аналоги пиридоксина. Это 4-метоксипиридоксин, токсопиримидин, изоникотинилгидразид и многие другие. Большинство из синтетических аналогов обладают свойствами антивитаминов $\mathrm{B}_{6}$. По принципу конкурентного ингибирования они вытесняют пиридоксин и его производные из биохимических реакций и тем самым вызывают авитаминоз $\mathrm{B}_{6}$. Если после этого ввести пиридоксин, признаки авитаминоза исчезают.

\section{Основы метаболизма}

В составе пищевых продуктов мы получаем вит. В6 в виде пиридоксина (пиридоксола), пиридоксаля и пиридоксамина. Эти соединения в пище находятся в связанном состоянии, в основном в соединении с остатком фосфорной кислоты. При поступлении в организм эта связь теряется, и витамеры дефосфорилируются. Далее они в свободном состоянии всасываются в тонком кишечнике. В норме процесс всасывания протекает довольно легко, путем простой диффузии. Таким образом, пиридоксаль и пиридоксамин могут поступать в организм извне или трансформироваться из пиридоксина в ходе некоторых неферментативный реакций. После того как витамеры витамина $\mathrm{B}_{6}$ попали в ткани, они, при участии ферментов-фосфокиназ, вновь фосфорилируются с образованием активных соединений пиридоксаль-5-фосфата и пиридоксамин-5-фосфата. Следует отметить, что накопление вит $\mathrm{B}_{6}$ идет неравномерно. В наибольшем количестве он содержится в миокарде, в печени, а также в почках. Конечные продукты обмена вит. $\mathrm{B}_{6}$ : 4-пиридоксиловая и 5-фосфопиридоксиловая кислоты. В виде этих соединений витамин и выводится почками. 


\section{Физиологические функции}

Пиридоксаль-5-фосфат является коферментом, небелковой составной частью ферментов. Как кофермент он входит в состав ферментных систем, обеспечивающих синтез ряда аминокислот - цистеина, глутамина, триптофана, гистидина, и некоторых других. Некоторые из аминокислот не только синтезируются, но и превращаются друг в друга при участии вит. $\mathrm{B}_{6}$. Этот витамин транспортирует аминокислоты через клеточные мембраны и участвует в синтезе многих белковых соединений. Помимо этого, коферменты-производные пиридоксина регулируют жировой и липидный обмен, участвуют в синтезе многих биологически активных веществ, в том числе серотонина, адреналина, норадреналина, гистамина, половых гормонов, ПНЖК.

Со стороны органов и систем действие вит. $\mathrm{B}_{6}$ проявляется следующим образом.

- Сердечно-сосудистая система. Благодаря синтезу ПНЖК и снижению уровня низкоплотного холестерина оказывает антиатеросклеротическое действие. Препятствует образованию атеросклеротических бляшек, и тем самым снижает риск развития инфаркта миокарда. Повышает силу сокращения миокарда, и предотвращает застойную сердечную недостаточность. Регулирует АД.

- Эндокринная система. Под действием вит. $\mathrm{B}_{6}$ повышается количество инсулина, выделяемого поджелудочной железой. Это обеспечивает утилизацию глюкозы и препятствует развитию сахарного диабета.

- Нервная система. Антиатеросклеротический эффект в сосудах головного мозга предупреждает развитие мозговых инсультов. Помимо этого, пиридоксин регулирует торможение и возбуждение в ЦНС. Витамин В 6 облегчает утилизацию глюкозы в мозговой ткани, участвует в синтезе веществ-нейромедиаторов (норадреналин, серотонин, дофамин). В результате формируется позитивный эмоциональный настрой, нормализуется сон, улуч- 
шаются мышление и память, повышается умственная работоспособность.

- ЖКТ и печень. Стимулирует образование соляной кислоты и ее выделение в составе желудочного сока. Также стимулирует образование желчи печенью и ее последующее выделение. Препятствует застою желчи с камнеобразованием в желчевыводящих путях. Способствует регенерации печеночных клеток, усиливает нейтрализацию токсинов в печени. Стимулирует синтез гликогена и его депонирование в печени.

- Мочевыделительная система. Оказывает диуретическое (мочегонное) действие. Регулирует выделение минеральных соединений с мочой. Препятствует камнеобразованию в почечных лоханках

- Костно-мышечная система. Способствует накоплению в скелетной мускулатуре креатинина - высокоэнергетического соединения, обеспечивающего силу мышечных сокращений.

- Иммунная система. Наряду с эритроцитами стимулирует синтез лейкоцитов и антител. Благодаря этому активирует звенья неспецифического клеточного и специфического гуморального иммунитета, повышает сопротивляемость организма инфекциям.

- Кожа и ее производные. Участвуя в обменных процесcax, вит. В 6 повышает барьерную функцию кожи и слизистых оболочек, формирует их прочность и эластичность, обеспечивает регенерацию при повреждениях и заболеваниях. Стимулирует рост волос и ногтей.

\section{Содержание в продуктах, суточные нормативы потребления}

Определенная часть вит. В6 синтезируется физиологической (молочнокислые бактерии, бифидумбактерии) и условнопатогенной (кишечная палочка) микрофлорой кишечника. Но количество эндогенного пиридоксина невелико, намного мень- 
ше имеющейся потребности. Чтобы удовлетворить эту потребность, необходимо получать вит. $\mathrm{B}_{6}$ с пищей (табл. 11,12$)$.

Таблица 11

Рекомендуемые нормы потребления пиридоксина

\begin{tabular}{|c|c|c|}
\hline Категория & Возраст & Норма, мг \\
\hline \multirow{2}{*}{ Грудные дети } & До 6 мес. & 0,5 \\
\hline & 6 мес. -1 год & 0,6 \\
\hline \multirow{3}{*}{ Дети } & 1-3 года & 0,9 \\
\hline & 4-6 лет & 1,3 \\
\hline & $7-10$ лет & 1,6 \\
\hline \multirow{5}{*}{ Мужчины } & $11-14$ лет & 1,8 \\
\hline & 15-18 лет & 2,0 \\
\hline & $18-59$ лет & 2,0 \\
\hline & 60-74 года & 2,2 \\
\hline & Старше 75 лет & 2,2 \\
\hline \multirow{7}{*}{ Женщины } & $11-14$ лет & 1,6 \\
\hline & $15-18$ лет & 1,6 \\
\hline & $18-59$ лет & 1,8 \\
\hline & 60-74 года & 2,0 \\
\hline & Старше 75 лет & 2,0 \\
\hline & Беременные & 2,1 \\
\hline & Кормящие & 2,3 \\
\hline
\end{tabular}

Таблица 12

Содержание пиридоксина в продуктах питания

\begin{tabular}{|l|c|}
\hline \multicolumn{1}{|c|}{ Продукт } & Содержание, мг/100 г \\
\hline Говядина & 0,4 \\
\hline Свиная печень & 0,5 \\
\hline Печень куриная & 0,9 \\
\hline Сельдь атлантическая & 0,4 \\
\hline Горбуша & 0,61 \\
\hline Твердые сорта сыра & $0,09-0,42$ \\
\hline Творог & 0,19 \\
\hline Мука пшеничная & 2,0 \\
\hline Сметана & 0,7 \\
\hline Желток куриного яйца & 0,46 \\
\hline
\end{tabular}


Окончание табл. 12

\begin{tabular}{|l|c|}
\hline \multicolumn{1}{|c|}{ Продукт } & Содержание, мг/100 г \\
\hline Грецкий орех & 0,8 \\
\hline Фундук & 0,7 \\
\hline Гречневая крупа & 0,4 \\
\hline Горох лущеный & 0,3 \\
\hline Отруби пшеничные & 1,3 \\
\hline Семечки & 1,34 \\
\hline Чеснок & 1,23 \\
\hline Картофель & 0,3 \\
\hline Кукуруза & 0,48 \\
\hline Ячмень & 0,47 \\
\hline Просо & 0,46 \\
\hline Арахис & 0,35 \\
\hline Абрикос & 0,05 \\
\hline Виноград & 0,08 \\
\hline Кабачки & 0,11 \\
\hline Яблоки & 0,04 \\
\hline Грибы белые сушеные & 0,41 \\
\hline
\end{tabular}

\section{Эпидемиология}

В Соединенных Штатах Америки и других западных странах дефицит встречается редко при адекватном питании, включая источники $\mathrm{B}_{6}$ из рыбы, мясных субпродуктов, птицы, картофеля, зерновых, бобовых и нецитрусовых фруктов.

Изолированный дефицит $\mathrm{B}_{6}$ встречается редко и обычно встречается в сочетании с другими недостатками витаминов группы В, такими как фолиевая кислота и $\mathrm{B}_{12}$.

Специфические клинические симптомы дефицита $\mathrm{B}_{6}$ обусловливаются недостаточным всасыванием в ЖКТ, печеночной дисфункцией, белково-энергетической недостаточностью и лекарственным взаимодействием или антагонизмом.

$\mathrm{B}$ организме человека $\mathrm{B}_{6}$ не депонируется, поэтому необходим ежедневный источник. Биодоступность $\mathrm{B}_{6}$ лучше у растительных источников этого витамина. Это может быть важно 
для тех, кто предпочитает исключительно растительную диету. Эти люди могут нуждаться в дополнительных добавках. Основной добавкой к мультивитаминам является пиридоксина гидрохлорид.

\section{Симптомы дефицита и избытка}

Основные причины гиповитаминоза $\mathrm{B}_{6}$.

- Нерациональное питание. При низком содержании вит. $\mathrm{B}_{6}$ в принимаемой пище будет развиваться его авитаминоз. Употребление белка сопровождается усиленным расходом витамина $\mathrm{B}_{6}$. Поэтому прием белковой пищи также в определенной степени способствует авитаминозу $\mathrm{B}_{6}$. У маленьких детей, рано перешедших на искусственное вскармливание, тоже повышается риск авитаминоза $\mathrm{B}_{6}$.

- Заболевания ЖКТ. При воспалительных заболеваниях желудка и кишечника всасывание пищевого витамина $\mathrm{B}_{6}$ будет нарушено. Снижение ферментообразующей функции печени, поджелудочной железы при некоторых генетических аномалиях и приобретенных заболеваниях (гепатиты, панкреатиты) также могут приводить к дефициту пиридоксина.

Помимо этого, существует ряд физиологических и патологических факторов, которые сопровождаются повышенным расходом пиридоксина: умственные и физические нагрузки, период бурного роста и полового созревания, инфекционные заболевания с лихорадкой, другие тяжелые заболевания: злокачественные новообразования, туберкулез, ВИЧ, патология щитовидной железы, аллергические реакции, злоупотребление алкоголем и курение, прием гормональных контрацептивов, антидепрессантов и антибиотиков.

Все эти факторы на фоне неполноценного питания и заболеваний ЖКТ с большой долей вероятности приведут к гиповитаминозу $\mathrm{B}_{6}$. При этом негативные изменения затронут все важнейшие системы органов. 
- Нервная система. Общая слабость, эмоциональная неустойчивость, расстройства сна, ухудшение мыслительных способностей, памяти. При выраженном дефиците отмечаются судорожные подергивания в мышцах. Судороги при авитаминозе $\mathrm{B}_{6}$ В основном возникают у грудных детей. У взрослых из-за поражения периферических нервов отмечается онемение, снижение чувствительности и угнетение сухожильных рефлексов.

- Сердечно-сосудистая система. Атеросклероз, дистрофические изменения в миокарде с застойной сердечной недостаточностью, повышение АД.

- ЖКТ. Ухудшение или отсутствие аппетита, гастродуодениты, энтероколиты, кишечный дисбактериоз, желчнокаменная болезнь. При этом пациенты жалуются на вздутие живота, диарею.

- Мочевыделительная система. МКБ, ухудшение фильтрационной способности почек.

- Кожа и ее производные. Снижение упругости и эластичности кожи, сухость и шелушение кожи, особенно на лице. Из-за дисфункции сальных желез развивается себорейный дерматит. Поражение полости рта принимает характер глосситов, стоматитов и хейлоза с трещинами на губах и характерными «заедами» в углах рта. Рост волос и ногтей замедляется. Волосы становятся ломкими, быстро выпадают.

- Система кроветворения. Гипохромная анемия. При тяжелых формах авитаминоза возможен переход на мегалобластный тип кроветворения, когда предшественники эритроцитов, мегалобласты, появляются в периферической крови.

- Эндокринная система. Сахарный диабет (СД), дисфункция щитовидной железы.

- Иммунная система. Снижение иммунитета на фоне лейкопении (уменьшения количества лейкоцитов), восприимчивость к инфекционным заболеваниям.

- Костно-мышечная система. Низкая толерантность к физическим нагрузкам, мышечная слабость, сопровождающаяся ощущением онемения. В суставах развиваются дегенеративные изменения по типу артрозов. 
Наряду с этими симптомами при дефиците вит. $\mathrm{B}_{6}$ нередко отмечается увеличение массы тела, которое обусловлено двумя факторами: первый - это ожирение из-за нарушения липидного обмена; второй - снижение диуреза (объема выделяемой мочи) и накопление жидкости в мягких тканях в виде отеков. У беременных авитаминоз $\mathrm{B}_{6}$ - одна из причин ранних токсикозов с тошнотой, рвотой, дерматитами, судорогами, выпадением зубов. У детей данное состояние проявляется задержкой физического и психического развития.

Как и многие водорастворимые витамины, пиридоксин не накапливается в тканях. Поэтому гипервитаминоз $\mathrm{B}_{6}-$ явление редкое. Он развивается лишь при поступлении синтетических аналогов в больших дозах, от 200 до 5000 мг и выше. В этих случаях отмечается кожный зуд и сыпь, расстройства чувствительности в конечностях, общая слабость, головокружение и судороги.

\section{Акушерские и перинатальные результаты дефицитарных состояний}

Дефицит $\mathrm{B}_{6}$ во время беременности способствует развитию дефектов нервной трубки плода и может способствовать развитию преэклампсии. Уровни потребления тиамина $\left(\mathrm{B}_{1}\right)$, пиридоксина $\left(\mathrm{B}_{6}\right)$ и ниацина $\left(\mathrm{B}_{3}\right)$ в преконцепции были гораздо ниже у матерей, родивших детей с расщелиной нёба. Достаточное употребление вит. В $_{6}$ способствует уменьшению уровней гомоцистеина, увеличивает вероятность зачатия и уменьшает риск спонтанной потери плода. Метаанализ пяти исследований, включавший более 1600 женщин, показал, что употребление вит. В 6 уменьшает риск рассасывания эмали зубов у беременных и рождение ребенка с низким весом.

У беременных дефицит вит. $\mathrm{B}_{6}$ очень распространен, особенно в ранние сроки. Дефицит пиридоксина сопряжен с повышенной частотой судорог, парестезий, с тревожным состоянием психики, рвотой, кариесом. 
Для клинической картины гиповитаминоза $\mathrm{B}_{6}$ характерны перхоть, сухие дерматиты в области носогубной складки, над бровями, около глаз, иногда на шее и волосистой части головы. Беременных при дефиците пиридоксина часто беспокоят тошнота, рвота, снижение аппетита, раздражительность, бессонница. Критический период беременности по дефициту пиридоксина 9-14 недель.

Гиповитаминоз В $_{6}$ у беременных может возникнуть при повышенной нагрузке белками, богатыми триптофаном, метионином, цистеином; при приеме медикаментов, которые подавляют обмен пиридоксина в организме, а также при сопутствующих кишечных инфекциях, гепатите, при проживании в зонах радиационного загрязнения. При $\mathrm{B}_{6}$-авитаминозе развиваются эпилептические судороги. У детей выделяют пиридоксинзависимую форму эпилепсии. При отягощенной по эпилепсии наследственности следует предусмотреть пиридоксиновую защиту.

\section{Способы лабораторной диагностики}

Уровень пиридоксина определяют в плазме крови методом жидкостной хроматографии с масс-селективным детектированием. Референсные значения: 5-50 нг/мл. Тест используют для оценки статуса вит. $\mathrm{B}_{6}$ и в диагностике гипофосфатазии. При проведении исследования в целях диагностики гипофосфатазии не рекомендуется употреблять витаминные добавки в течение недели до взятия крови на анализ во избежание ложноположительного результата.

\section{Варианты коррекции}

Наиболее популярен синтетический вит. $\mathrm{B}_{6}$ в виде пиридоксина гидрохлорида. Формы выпуска препарата: таблетки для детей - 2 мг, таблетки для взрослых - 10 мг, ампулы объемом 1 мл $-1 \%, 2,5 \%$ и 5\%-ный раствор. Самой удобной формой, 
разумеется, являются таблетки для приема внутрь. Однако при болезнях ЖКТ всасывание вит. В 6 в кишечнике может быть затруднено. В этих случаях предпочтителен раствор, который можно вводить внутримышечно или внутривенно. Наряду с пи-

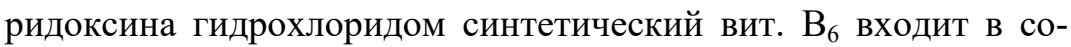
став многих витаминно-минеральных комплексов («МультиТабс», «Витрум», «Компливит», «Гексавит» и др.), а также косметических средств по уходу за кожей и волосами.

Взаимодействие с другими средствами. Кортикостероиды (дексаметазон, преднизолон, гидрокортизон и др.) усиливают выведение пиридоксина из организма. Синтетические эстрогены (в том числе и оральные контрацептивы), противосудорожные и противотуберкулезные средства, иммунодепрессанты разрушают вит. В $_{6}$. Пеницилламин, купренил и другие комплексообразующие антидоты связывают вит. $\mathrm{B}_{6}$ и инактивируют его. Витамин $\mathrm{B}_{6}$ снижает активность ряда противопаркинсонических препаратов. Нельзя сочетать вит. В 6 с эуфиллином, фенитоином, снотворными и седативными средствами, так как это ведет к ослаблению их действия. Диуретический эффект мочегонных препаратов пиридоксин усиливает. Алкоголь затрудняет всасывание вит. $\mathrm{B}_{6}$ в кишечнике. Витамин $\mathrm{B}_{6}$ облегчает всасывание железа, магния. Магний, в свою очередь, положительно влияет на усваивание вит. $\mathrm{B}_{6}$. Также вит. $\mathrm{B}_{6}$ снижает потерю цинка, хорошо совместим с медью и кальцием. Витамин $\mathrm{B}_{2}$ (рибофлавин) активирует вит. В6. В свою очередь пиридоксин повышает активность вит. В 9 (фолиевой кислоты). А вот активацию вит. В (тиамина) он, наоборот, тормозит. А вит. $\mathrm{B}_{12}$ (цианокобаламин) разрушает вит. $\mathrm{B}_{6}$. Тем не менее эти три витамина, вит. $\mathrm{B}_{1}, \mathrm{~B}_{6}$, и $\mathrm{B}_{12}$, в сбалансированных количествах присутствуют во многих витаминно-минеральных препаратах. В комплексе с другими витаминами и минералами их активность не снижается. 


\section{7. ВИТАМИН В 8 (ИНОЗТОЛ)}

Витамин В 8 (инозит, инозитол) классифицируют как водорастворимый витамин. Однако его принадлежность к витаминам многие оспаривают и причисляют инозитол к витаминоподобным соединениям. Но, вне зависимости от того, является инозитол истинным витамином или витаминоподобным веществом, он играет важную роль в процессах жизнедеятельности. Из-за омолаживающего действия инозитол называют витамином молодости. Другое образное название - природное снотворное - подчеркивает седативный эффект инозитола.

Первооткрывателем инозитола принято считать великого немецкого химика Либиха. В 1848 г. он выделил из мясного бульона сладковатое вещество. Вскоре были изучены физические и химические свойства этого вещества. Немногим позже, в 1895 г., другой ученый, Палладин, получил из растительного сырья шестиатомный спирт и назвал его фитиновой кислотой. Уже тогда было сделано предположение о благотворном влиянии инозитола на состояние организма человека и животных. Поскольку данный витамин был водорастворимым, его отнесли к витаминам группы В и дали порядковый номер 8. Однако на фоне своих именитых «собратьев»- вит. А, E, D, PP, B $, \mathrm{B}_{2}, \mathrm{~B}_{6}$, $\mathrm{B}_{12}$ инозитол выглядел довольно тускло. Во-первых, его полезные свойства не были достаточно изучены. А во-вторых, не были определены признаки недостаточности. Из этого был сделан вывод, что особой пользы инозитол не приносит, и вреда при его дефиците тоже нет. Поэтому его сочли не витамином, а витаминоподобным веществом. Однако в ходе последующих опытов были установлены его полезные свойства. Добавление в пищу инозитола благотворно влияло на подопытных крыс. У животных приостанавливалось выпадение шерсти и снижался уровень холестерина в крови. Вскоре ученые установили, что 
инозитол - необходимый компонент для выращивания культур клеток человека и животных. Однако за признанием последовала неудача. Выделенный из растительного сырья, инозитол связывал в желудке ионы кальция, цинка, железа, что сопровождалось анемией и рахитом. Поэтому вит. $\mathrm{B}_{8}$ вновь предали забвению, но лишь на некоторое время. В 80-х гг. прошлого века получили распространение так называемые болезни цивилизации: сердечно-сосудистые заболевания, ожирение, расстройства психики, алкоголизм, наркомания. В это же время благодаря передовым технологиям расширились возможности научнотехнических исследований. В ходе этих исследований была более подробно определена молекулярная структура инозитола и изучена его роль в протекании важнейших физиологических процессов.

Инозитол представляет собой белый кристаллический, сладковатый на вкус порошок. Кристаллы гигроскопичны, не стойки к нагреванию и плавятся при температуре $224-227{ }^{\circ} \mathrm{C}$. Устойчив к действию компонентов внешней среды - атмосферному кислороду и солнечному свету, действию кислот и щелочей.

Инозитол является производным глюкозы, но сам углеводом не является. Это шестиатомный циклический спирт с химической формулой $\mathrm{C}_{6} \mathrm{H}_{12} \mathrm{O}_{6}$ и номенклатурным названием цис-1,2,3,5-транс-4,6-циклогексангексаол. Структурные элементы молекулы инозитола имеют различную пространственную ориентацию. В связи с этим различают девять стереоизомеров инозитола. Из них наиболее значимым с физиологической точки зрения является мио-инозитол. Когда говорят о вит. $\mathrm{B}_{8}$ или инозитоле, то подразумевают именно мио-инозитол. Упомянутая выше фитиновая кислота, или инозитгексафосфат, представляет собой не что иное, как сложный эфир мио-инозитола. 


\section{Основы метаболизма}

Экзогенный инозитол, поступивший извне в составе пищи или лекарственных препаратов, быстро всасывается в кишечнике и поступает в кровь. Эндогенный инозитол, синтезируемый миокардом, почками, печенью и другими тканями, тоже направляется в системный кровоток. Вместе с кровью он разносится по органам и тканям, где присутствует в виде солей или сложных органических соединений с белками и жирами (липидами). Количество инозитола в тканях неодинаково. Больше всего вит. $\mathrm{B}_{8}$ там, где этот витамин не может синтезироваться, но где имеется жизненная потребность в нем. Поэтому много инозитола содержится в головном и в спинном мозге, а также в спинномозговой жидкости (ликворе). Инозитол в значительном количестве присутствует в скелетных мышцах и в структурах глаза - в глазном дне, в хрусталике и в слезной жидкости. Также его обнаруживают в семенной жидкости у мужчин. Для того чтобы органы и ткани не испытывали недостатка в инозитоле, в крови поддерживается его постоянная концентрация около 4,5 мкг/л. Однако в организме он не накапливается. Излишек инозитола в неизменном виде выводится с мочой. При этом его количество в моче у здоровых людей невелико и повышается при сахарном диабете. Дело в том, что выделение глюкозы с мочой у диабетиков угнетает реабсорбцию (обратное всасывание) инозитола в почечных канальцах, что является дополнительным фактором, предрасполагающим к его дефициту.

Инозитол считается псевдовитамином и относится к комплексу витаминов группы В, однако определение инозитола как витамина не совсем корректно, поскольку он вырабатывается человеческим организмом в достаточном количестве из D-глюкозы. Это происходит в печени, почках и головном мозге. Инозитол был описан как вторая мессенджерная система, которая может оказывать инсулиноподобное действие на метаболические ферменты и, следовательно, улучшать чувствительность к инсулину. 
Наиболее важными изомерами инозитола являются мио-, хиро- (L-хиро и D-хиро), муко-, сцилло- и нео-миоинозитол, также известный как 1,2,3,5-транс-4,6-циклогексангексол, является преобладающей изомерной формой инозитола, которая содержится в клетках животных и растений. Он встречается в свободной форме или в составе фосфолипидов, или в виде фитиновой кислоты. Мио-инозитол является компонентом мембран всех живых клеток. Он также играет определенную роль в синтезе липидов.

\section{Физиологические функции}

Биологическая ценность инозитола:

- регулирует основные виды обмена веществ;

- входит в состав многих ферментов в виде производных соединений, фосфоинозитидов;

- входит в состав клеточных мембран;

- регулирует объем внутриклеточного пространства;

- стимулирует рост и регенерацию тканей;

- является отличным антиоксидантом.

Инозитол позитивно влияет на состояние жизненно важных органов и систем.

- Нервная система. Эффекты инозитола проявляются как в ЦНС, так и в периферических нервах. Витамин В 8 обеспечивает полноценную передачу нервных импульсов по нервным волокнам. Также он предохраняет нервные клетки (нейроны) от повреждающих факторов. Благодаря этому полноценно функционируют периферические чувствительные и двигательные нервы. На ЦНС инозитол действует как транквилизатор и седативное средство. Этот витамин формирует позитивный эмоциональный настрой, устраняет негативные ощущения тревоги, депрессии, навязчивых страхов. А еще инозитол - это хорошее природное снотворное. Он нормализует сон и устраняет бессонницу. Наряду с другими факторами это вещество оптимизирует соотношение фаз быстрого и медленного сна. 
- Сердечно-сосудистая система. Как антиоксидант инозитол предохраняет миокард и эндотелий от свободнорадикального окисления. Он повышает прочность не только эндотелия, но и всей сосудистой стенки, и снижает ее проницаемость для плазмы и форменных элементов крови. На саму кровь инозитол оказывает разжижающее действие. Также инозитол снижает уровень холестерина низкой плотности.

- ЖКТ. Витамин В 8 стимулирует моторику ЖКТ, формирует чувство насыщения после приема пищи. Поэтому он защищает от переедания и помогает легче переносить ограничительные диеты для снижения массы тела. В кишечнике инозитол создает условия, благоприятные для роста и размножения физиологической микрофлоры. Подтверждено благотворное влияние инозитола на состояние печени. Это вещество предохраняет печень от хронической интоксикации алкоголем и принимаемыми лекарствами. Как антиоксидант вит. $\mathrm{B}_{8}$ защищает гепатоциты от действия свободных радикалов. Инозитол предупреждает появление гепатозов. Инозитол стимулирует образование желчи в печени и ее выведение желчевыводящей системой, улучшает состояние желчного пузыря и препятствует развитию в нем местных воспалительных процессов - холециститов. Также имеются данные, что инозитол снижает риск злокачественных новообразований в органах пищеварения, в частности рака печени, рака прямой кишки и рака поджелудочной железы.

- Костно-мышечная система. Инозитол стимулирует белковый обмен и способствует накоплению белков в мышцах, увеличение мышечной массы и повышение физической силы и выносливости. Не зря это вещество было выделено Либихом именно из мясного бульона. Примечательно, что само название витамина происходит от древнегреческого inos, что переводится как мускул, мышечное волокно. Поначалу витамин назвали инозитом. И только позже, когда в ходе исследований было установлен, что это спирт, его стали называть инозитолом (суффикс «-ол» в названии вещества указывает на принадлежность к спир- 
там). Инозитол повышает прочность сухожилий, костей, связочного аппарата.

- Эндокринная система. Инозитол способствует клеточному усваиванию глюкозы. Он усиливает чувствительность мембран нервных клеток к инсулину поджелудочной железы. Это имеет большое значение при сахарном диабете 2-го типа, спровоцированном ожирением, для которого характерно развитие инсулинорезистентности - устойчивости клеток жировой ткани к действию физиологических концентраций инсулина. Инозитол снижает эту резистентность, и сахарный диабет 2-го типа не развивается. При уже развившемся сахарном диабете вит. $\mathrm{B}_{8}$ предотвращает развитие диабетических осложнений со стороны нервных волокон, кровеносных сосудов и сетчатки глаза.

- Органы зрения. Наряду с другими веществами, инозитол поддерживает физиологическое состояние светопроводящей системы глаза и глазного дна, тем самым повышая остроту зрения.

- Органы дыхания. Укрепляет слизистую оболочку бронхов, повышает ее устойчивость к инфекционным агентам. У курильщиков инозитол замедляет формирование бронхиальной дисплазии, являющейся предраковым состоянием.

- Кожа и ее производные. Под действием инозитола происходит регулярное обновление кожного эпидермиса. Этот витамин обеспечивает своевременную регенерацию кожи при воспалительных процессах и повреждениях. Витамин $\mathrm{B}_{8}$ препятствует развитию меланомы. Также вит. $\mathrm{B}_{8}$ способствует усиленному росту волос и предотвращает их преждевременное выпадение.

\section{Содержание в продуктах, суточные нормативы потребления}

Строгих норм инозитола нет, ведь это не истинный витамин, а витаминоподобное вещество. К тому же значительное количество необходимого инозитола наш организм синтезирует сам. Поэтому приведенные данные носят большей частью реко- 
мендательный характер. Взрослому человеку необходимо минимум 500 мг инозитола в сутки. При состояниях, способствующих дефициту инозитола, потребность в этом веществе может увеличиваться до 5-8 г в сутки (табл. 13).

Рекомендуемые нормы потребления инозитола

\begin{tabular}{|l|c|}
\hline \multicolumn{1}{|c|}{ Категория } & Норма, мг \\
\hline Дети до года & $30-40$ \\
\hline Дети 1-3 лет & $50-60$ \\
\hline Дети 4-6 лет & $80-100$ \\
\hline Дети и подростки 7-18 лет & $200-500$ \\
\hline Взрослые & $500-1000$ \\
\hline Беременные женщины & 3000 \\
\hline
\end{tabular}

Значительная часть инозитола, до 75-80 \%, синтезируется из глюкозы в различных тканях организма. Особенно много его образуется в сердце, в почках и в печени. И лишь небольшая часть, примерно четверть, поступает извне в составе пищевых продуктов (табл. 14).

Содержание инозитола в продуктах питания

\begin{tabular}{|l|c|}
\hline \multicolumn{1}{|c|}{ Продукт } & Содержание, мг/100 г \\
\hline Пшеница цельная & 370 \\
\hline Пшеница пророщенная & 724 \\
\hline Рисовые отруби & 460 \\
\hline Рис пророщенный & 370 \\
\hline Семя кунжута & 750 \\
\hline Грецкий орех & 77 \\
\hline Горох & 240 \\
\hline Говядина & 12 \\
\hline Печень говяжья & 54 \\
\hline Мясо куриное & 44 \\
\hline Свинина & 38 \\
\hline Яйца & 38 \\
\hline Камбала & 22 \\
\hline
\end{tabular}


Окончание табл. 14

\begin{tabular}{|l|c|}
\hline \multicolumn{1}{|c|}{ Продукт } & Содержание, мг/100 г \\
\hline Консервированный лосось & 18 \\
\hline Апельсин & 210 \\
\hline Грейпфрут & 150 \\
\hline Персик & 96 \\
\hline Картофель & 66 \\
\hline Помидоры & 46 \\
\hline Цветная капуста & 95 \\
\hline
\end{tabular}

\section{Симптомы дефицита и избытка}

Поскольку некоторое количество инозитола мы получаем вместе с пищевыми продуктами, то можно было бы предположить, что недостаточное поступление его с пищей приведет к гиповитаминозу. Однако сам по себе дефицит вит. В 8 в пищевых продуктах вряд ли является значимым в плане гиповитаминоза $\mathrm{B}_{8}$. Здесь намного опаснее различные состояния, при которых происходит массивное разрушение или выведение вит. $\mathrm{B}_{8}$. Прежде всего, это сахарный диабет. Во-первых, при этом заболевании для внутриклеточной утилизации глюкозы требуется большее количество инозитола, что и предрасполагает к дефициту. Во-вторых, при значительном повышении глюкозы в крови развивается полиурия - усиленное мочеотделение. При этом инозитол усиленно выводится с мочой. В связи с этим не только сахарный, но и несахарный диабет приведет к потере вит. $\mathrm{B}_{8}$. Несахарный диабет - редкое заболевание, при котором нарушается выработка гипоталамусом вазопрессина. Основное проявление этой патологии - полиурия и, как следствие, тоже усиленное выведение инозитола.

Повышенное выведение инозитола с мочой будет отмечаться при некоторых хронических заболеваниях почек, протекающих по типу нефритов. Регулярные физические нагрузки (тяжелый труд, спортивные тренировки) также снижают коли- 
чество этого витамина. Во-первых, при физической работе инозитол усиленно расходуется. Во-вторых, возникает жажда, а обильное питье способствует выведению вит. $\mathrm{B}_{8}$ через почки.

Витамин $\mathrm{B}_{8}$ расходуется при умственном труде, психоэмоциональных стрессах, хотя и в гораздо меньшем количестве, чем при физических нагрузках. Некоторые из лекарств - антибиотики, сульфаниламиды, гормональные контрацептивы - угнетают всасывание инозитола. Прием алкоголя способствует его более интенсивному разрушению. Аналогичным образом действует кофеин в составе кофе, чая и многочисленных прохладительных напитков. При дефиците белков в составе принимаемой пищи синтез собственного вит. В 8 ухудшается.

Специфических признаков гиповитаминоза $\mathrm{B}_{8}$ не существует. При этом состоянии обращают на себя внимание психоневрологические расстройства различной тяжести. Появляются плаксивость, раздражительность, нарушения сна, склонность к депрессиям. При выраженном гиповитаминозе пациенты утрачивают способность к адекватному восприятию окружающей действительности: ухудшается мышление, запоминание, появляются панические навязчивые страхи. Пациентов беспокоит бессонница ночью и сонливость днем. На фоне этих изменений эмоционально-волевой сферы нарушается координация движений, а мышечная сила и физическая выносливость снижаются. Нарушения со стороны ЖКТ проявляются угнетением перистальтики кишечника и запорами. При злоупотреблении алкоголем и других провоцирующих факторах повышается риск стеатогепатоза. Появляется склонность к ожирению, которое, в свою очередь, приводит к инсулинорезистентности и сахарному диабету 2-го типа. В крови повышается уровень Х-ЛПНП и триглицеридов. Развивается атеросклероз, который в сочетании с патологическим тромбообразованием приводит к тяжелым сердечнососудистым заболеваниям.

Ухудшается внешний вид пациента с гиповитаминозом $\mathrm{B}_{8}$. Кожа становится сухой, на ней появляется сыпь. Нередко разви- 
ваются дерматиты и экзема. Волосы становятся ломкими. Их выпадение носит диффузный или очаговых (алопеция) характер. Появляются другие признаки раннего старения. Прогрессивно ухудшается острота зрения, в пожилом возрасте развивается катаракта. Нарушения в репродуктивной системе мужчин и женщин проявляются различными видами бесплодия.

Поскольку водорастворимый инозитол в организме не накапливается, гипервитаминоз $\mathrm{B}_{8}$ в естественных условиях не развивается. При массивном поступлении синтетических аналогов возможно появление крапивницы, одышки и повышения давления. Но для того чтобы появились эти симптомы, нужно, чтобы инозитол поступал в дозах, примерно в 100 раз превышаемых рекомендуемые. Поэтому вероятность гипервитаминоза $\mathrm{B}_{8}$ чисто теоретическая.

\section{Участие в репродукции}

Инозитол обеспечивает фертильность - способность к воспроизводству, предупреждает мужское и женское бесплодие. У мужчин под действием инозитола созревают сперматозоиды. Есть данные, что инозитол играет не последнюю роль в усилении потенции. Поскольку этот витамин обеспечивает проведение нервных импульсов, то под его действием при соответствующих зрительных образах и чувственных воздействиях наступает эрекция. Аналогичным способом инозитол действует на женщин.

Витамин $\mathrm{B}_{8}$ контролирует правильное созревание яйцеклеток и предупреждает развитие синдрома поликистозных яичников (СПКЯ). Один из этиопатогенетических факторов развития СПКЯ - инсулинорезистентность. Поэтому, снижая резистентность тканей к инсулину, инозитол предупреждает не только сахарный диабет 2-го типа, но и СПКЯ.

Также этот витамин предупреждает развитие рака молочных желез. Инозитол нормализует гормонпродуцирующую функ- 
цию яичников и менструальный цикл, уменьшает явления предменструального синдрома (ПМС) и предотвращает развитие женского бесплодия. При наступившей беременности инозитол способствует правильной дифференцировке плодных тканей, препятствует формированию аномалий развития ЦНС, глаз, бронхолегочной системы.

Инозитол играет важную роль в воспроизводстве путем улучшения качества яйцеклеток, восстановления овуляции и фертильности, снижения гиперандрогении и резистентности к инсулину.

\section{Акушерские и перинатальные результаты дефицитарных состояний}

Несмотря на то что молекулярный механизм действия мио-инозитола до конца не изучен, считается, что мио-инозитол связывается с глюкозамином для создания ингибитора инозитол-фосфогликан-аденозинмонофосфаткиназы (ИПГ-А), который приводит к увеличению синтеза жирных кислот путем ингибирования с-АМФ-зависимой протеинкиназы и аденилатциклазы. Кроме того, считается, что мио-инозитол благодаря своим инсулин-миметическим свойствам активирует транслокацию GLUT-4 на плазматическую мембрану и затем приводит к увеличению транспорта глюкозы через GLUT-4 в клетки. Согласно этим теориям, мио-инозитол может снизить инсулинорезистентность во время беременности, а добавление мио-инозитола может усилить действие эндогенного инсулина.

Мио-инозитол был протестирован для предотвращения и лечения гестационного диабета в ряде клинических исследований. Сообщалось, что высокие дозы мио-инозитола иногда вызывают незначительные побочные эффекты, такие как тошнота и диарея; однако отчеты о болезни показали безопасный профиль этой молекулы даже при высокой концентрации (4 г миоинозитола три раза в день в течение трех недель). Кроме того, 
была продемонстрирована его эффективность в отношении более быстрого и устойчивого снижения уровня глюкозы в крови. Эти результаты подчеркивают новые взгляды на использование мио-инозита для лечения ГСД.

Достоверных различий в риске развития гипертензивных нарушений беременности, макросомии плода, неонатальной гипогликемии, плечевой дистоции или частоты кесарева сечения между мио-инозитолом и контрольной группой не было. Ученые пришли к выводу, что прием мио-инозитола во время беременности благотворно влияет на снижение риска развития ГСД. Однако нет четких рекомендаций по дозировкам мио-инозитола, используемого для профилактики ГСД.

\section{Способы лабораторной диагностики}

В настоящее время в лабораторных тестах, представленных в Российской Федерации, отсутствуют специфические тесты, позволяющие определить уровень инозитола в организме.

\section{Варианты коррекции}

Инозитол входит в состав монопрепаратов или комплексных витаминно-минеральных соединений, представленных таблетками, капсулами и порошком для приема внутрь. Практически все синтетические аналоги инозитола являются БАД. Среди многочисленных препаратов, содержащих инозитол, самыми популярными являются: «Инозитол Мио», «Холин + Инозитол», «D-хиро-инозитол», «Иноферт», «Инофолик».

В гинекологической практике инозитол используют при дисгормональных нарушениях и инсулинорезистентности, сопровождающихся замедлением овуляции, СПКЯ и бесплодием. Многие средства по уходу за кожей и волосами содержат инозитол. Этот витамин включен в состав смесей для спортивного питания. 


\section{Взаимодействие с другими веществами}

Витамин Е улучшает усваивание вит. $\mathrm{B}_{8}$. В свою очередь вит. $\mathrm{B}_{8}$ улучшает усваивание многих витаминов группы В, в частности вит. В 9 (фолиевой кислоты). Вместе с вит. $\mathrm{B}_{4}$ инозитол участвует в синтезе лецитина. Алкоголь, кофеин, антибиотики, сульфаниламиды, синтетические эстрогены негативно влияют на активность и количество инозитола. Инозитол регулирует баланс цинка и меди. Однако в ряде случаев он угнетает всасывание цинка, магния и железа. Это происходит, если инозитол сочетается с фитиновой кислотой. Такое сочетание присутствует в некоторых бобовых, злаках, а также в темно-зеленых листовых овощных культурах. 


\section{8. ВИТАМИН В}

Витамин $\mathrm{B}_{9}$ (фолиевая кислота) является водорастворимым витамином. Из-за положительного влияния на мозговые функции и эмоциональный фон вит. В9 называют витамином хорошего настроения. Помимо этого, фолиевая кислота участвует в синтезе белков и нуклеиновых кислот, способствует росту, обновлению и восстановлению тканей. Открытие этого вещества связано с таким заболеванием, как мегалобластная анемия, которая была описана в 1926 г. ученым Ефремовым. В поисках действенного средства Ефремовым было установлено, что при употреблении продуктов, содержащих печень, состояние пациентов улучшалось. В 1931-1932 гг. английский врач Л. Уиллс изучала течение мегалобластной анемии у беременных женщин в условиях тропического климата Индии. Для того чтобы улучшить состояние, пациентки принимали очищенный экстракт из печеночной ткани. Однако ожидаемого улучшения при этом не наступало. Но после приема неочищенного экстракта болезнь регрессировала. Было сделано логичное предположение, что в печени содержится некий фактор, оказывающий целебное действие. Данный фактор по фамилии Уиллс назвали буковой U. Вскоре его выделили из печеночной ткани. Затем из пищевых дрожжей получили вещество, оказывающее аналогичное действие. В 1941 г. это же вещество было выделено из листьев шпината, и его назвали фолиевой кислотой (от лат. folium лист). В 1945 г. фолиевая кислота была синтезирована химическим путем. Данное вещество причислили к витаминам. Вновь отрытый витамин обозначили как вит. $\mathrm{B}_{9}$. Хотя в некоторых источниках можно встретить альтернативные наименования вит. Вс или вит. М. Таким образом, фактор U, вит. М, Вс и В9 обозначают одно и то же химическое соединение - фолиевую кислоту. 
Однако вит. $\mathrm{B}_{9}$ представлен не только фолиевой кислотой. Сюда входит множество веществ со сходной химической структурой и действием. Данные вещества, аналоги фолиевой кислоты, именуют фолатами. Помимо фолиевой кислоты эти вещества включают в себя фолиновую кислоту, фолат, фолацин, метафолин, и ряд других органических соединений естественного или синтетического происхождения. Но за вит. $\mathrm{B}_{9}$ закрепилось название основного компонента - фолиевой кислоты.

В химическом отношении фолаты являются производными птеридина. Молекулярная структура большинства этих соединений включает в себя ядро птероевой кислоты, парааминобензойную кислоту (ПАБК) и L-глутаминовую кислоту. Поэтому их еще обозначают как птероилглутаминовая кислота. Это собирательное понятие, которое помимо фолиевой кислоты включает в себя множество других фолатов. Некоторые вещества являются производными восстановленной тетрагидроптероилглутаминовой кислоты.

Основной компонент вит. $\mathrm{B}_{9}$ - фолиевая кислота - вещество с химической формулой $\mathrm{C}_{19} \mathrm{H}_{19} \mathrm{~N}_{7} \mathrm{O}_{6}$.

Внешне представляет собой мелкий кристаллический порошок желтого цвета без запаха и вкуса. Кристаллы разлагаются на свету, обугливаются при повышении температуры до $250{ }^{\circ} \mathrm{C}$. Несмотря на то что вит. В 9 относится к классу водорастворимых, в воде он растворяется плохо. Также он плохо растворяется во многих кислотах, спирте и органических растворителях (эфир, ацетон, бензол, хлороформ), но хорошо растворяется в щелочах.

\section{Основы метаболизма}

Поступившая извне фолиевая кислота в кишечнике подвергается ферментативному восстановлению с образованием тетрагидрофолиевой кислоты (ТГФК). Производные ТГФК всасываются в двенадцатиперстной кишке и в начальных отде- 
лах тощей кишки и с током крови поступают в печень. Здесь они трансформируются в активные формы. Печень способна накапливать фолаты. Накопленного количества хватает примерно на 4 месяца. Некоторые другие органы, в частности почки, кишечник, тоже способны накапливать фолаты, но в гораздо меньших объемах. В целом способность к кумуляции у вит. В9 невелика. К тому же она зависит от поступления других веществ: витаминов, лекарственных препаратов. Отработанные метаболиты фолиевой кислоты и других фолатов удаляются из организма с мочой и калом.

\section{Физиологические функции}

Продукты метаболизма фолатов в качестве коферментов участвуют во многих биохимических реакциях, протекающих в нашем организме. Эти предшественники ферментов стимулируют окислительно-восстановительные процессы с образованием белков, пуриновых и пиримидиновых оснований. Известно, что белки являются основным строительным материалом для клеток. А пурины включают в себя ДНК и РНК. Эти нуклеиновые кислоты обеспечивают синтез белковых соединений, специфичных именно для данного вида тканей, а также рост и правильное деление клеток. Поэтому роль вит. $\mathrm{B}_{9}$ особенно заметна там, где происходит интенсивное клеточное деление, обновление, восстановление (регенерация) и рост тканей. Это кровь, кожа с придатками, слизистые оболочки, мужские и женские гонады (половые железы), эмбриональные структуры. Наряду с белками, пуриновыми и пиримидиновыми основаниями, вит. В9 регулирует синтез липидов (жиров), углеводов, аминокислот, многих биологически активных соединений, выполняющих функцию витаминов, гормонов и нейромедиаторов. Поэтому действие фолиевой кислоты не ограничивается одними лишь быстрорастущими и обновляющимися тканями. 
Этот витамин в той или иной степени влияет на состояние всех систем органов.

- Система кроветворения. Влияние вит. В9 на кроветворение сходно с таковым у вит. $\mathrm{B}_{12}$ (цианокобаламина). Подобно цианокобаламину фолиевая кислота обеспечивает полноценное созревание эритроцитов в красном костном мозге. Витамин $\mathrm{B}_{9}$ способствует образованию гемоглобина. В результате этого «правильные» эритроциты с необходимым количеством гемоглобина полноценно насыщают ткани кислородом и удаляют углекислоту.

- Иммунная система. Фолиевая кислота стимулирует выработку различных видов лейкоцитов, обеспечивающих неспецифический клеточный и специфический гуморальный иммунитет. Под действием витамина устойчивость организма к инфекциям повышается, а при развившихся инфекционных заболеваниях выздоровление наступает быстрее.

- Сердечно-сосудистая система. Фолиевая кислота снижает количество Х-ЛПНП, под действием которого формируются внутрисосудистые атеросклеротические бляшки, закупоривающие артериальный просвет. Таким образом, вит. В9 препятствует развитию такого заболевания, как ИБС, которая проявляется приступами стенокардии, а при тяжелом течении осложняется инфарктом миокарда. Однако одним лишь снижением «плохого» низкоплотного холестерина действие фолиевой кислоты на сердце и сосуды не исчерпывается. Этот витамин влияет на количество гомоцистеина, который не участвует в синтезе белков, не поступает извне с пищей, а образуется в ходе метаболических процессов. На состояние кровообращения гомоцистеин действует крайне отрицательно. Он повреждает внутреннюю сосудистую оболочку, эндотелий. На поврежденном эндотелии быстрее образуются тромбы и атеросклеротические бляшки. Нарушается кровоток по коронарным артериям, артериям периферических участков тела, почек, сетчатки. Под действием вит. $\mathrm{B}_{9}$ количество гомоцистеина в плазме крови снижается. 
- Нервная система. Снижение уровня гомоцистеина улучшает мозговой кровоток и снижает вероятность развития инсультов. Витамин В 9 улучшает усвоение глутаминовой кислоты. Это нейромедиатор, регулирующий процессы торможения и возбуждения в ЦНС Фолиевая кислота также участвует в синтезе другого нейромедиатора - серотонина. Это один из так называемых гомонов счастья, ответственный за формирование позитивных эмоций. Именно поэтому фолиевую кислоту называют витамином хорошего настроения. Витамин В9 улучшает не только эмоции, но и мышление, помогает обрабатывать, систематизировать и запоминать поступающую информацию. Особенно это важно в юношеские и молодые годы, когда происходит интенсивное обучение, и в старости, когда появляется опасность болезни Альцгеймера. Фолиевая кислота входит в состав ликвора и спинномозговой жидкости.

- ЖКТ и печень. Фолиевая кислота укрепляет слизистые оболочки ЖКТ, предупреждает воспалительные и язвенные процессы. Она стимулирует выделение соляной кислоты слизистой желудка, повышает аппетит. В печени увеличивает количество вит. $\mathrm{B}_{4}$ (холина) и тем самым предотвращает ее жировую инфильтрацию.

- Дыхательная система. Улучшает барьерные свойства слизистых оболочек бронхов. На фоне укрепления иммунитета это снижает вероятность развития бронхитов и пневмоний.

- Почки и мочевыводящие пути. Улучшает почечный кровоток и фильтрационную функцию почек. Позитивно влияет на состояние почечных лоханок, слизистых оболочек мочевого пузыря и уретры.

- Эндокринная система. Фолиевая кислота обеспечивает усвоение тирозина. Эта аминокислота служит сырьем для многих гормонов (адреналин, дофамин, норадреналин, тироксин), вырабатываемых щитовидной железой, надпочечниками и мозговыми структурами. Помимо этого, вит. В 9 стимулирует синтез еще одного важного гормона, инсулина поджелудочной железы. Это особо значимо при сахарном диабете 1-го типа 
с абсолютной инсулиновой недостаточностью. Также вит. $\mathrm{B}_{9}$ способствует утилизации жиров и предотвращает ожирение, что важно при метаболическом синдроме, когда на фоне ожирения развивается сахарный диабет 2-го типа. При этом типе заболевания формируется относительная инсулиновая недостаточность. Инсулин вырабатывается в достаточном количестве, но его все равно не хватает из-за большого количества жировой ткани. Фолиевая кислота способствует утилизации жира. Из-за уменьшения количества жировой ткани устраняется относительная инсулиновая недостаточность, и течение сахарного диабета 2-го типа прерывается.

- Кожа и ее производные. Витамин $\mathrm{B}_{9}$ повышает прочность и эластичность кожи, способствует ее восстановлению после заболеваний и повреждений, стимулирует рост волос.

\section{Содержание в продуктах, суточные нормативы потребления}

Значительная часть фолиевой кислоты синтезируется микрофлорой толстого кишечника. Обычно этого количества вполне достаточно для удовлетворения физиологических нужд. Однако при заболеваниях ЖКТ, когда количество вит. В 9 снижается, возрастает роль пищевых продуктов, в состав которых входит фолиевая кислота (табл. 15, 16).

Таблица 15

Рекомендуемые нормы потребления фолиевой кислоты

\begin{tabular}{|c|c|c|}
\hline Категория & Возраст & Норма, мг \\
\hline \multirow{2}{*}{ Грудные дети } & До 6 мес. & 40 \\
\cline { 2 - 3 } & 6 мес. -1 год & 60 \\
\hline \multirow{3}{*}{ Дети } & $1-3$ года & 100 \\
\cline { 2 - 3 } & $4-6$ лет & 200 \\
\cline { 2 - 3 } & $7-10$ лет & 200 \\
\hline \multirow{2}{*}{ Мужчины } & $11-14$ лет & 200 \\
\cline { 2 - 3 } & $15-18$ лет & 200 \\
\hline
\end{tabular}


Окончание табл. 15

\begin{tabular}{|c|c|c|}
\hline Категория & Возраст & Норма, мг \\
\hline \multirow{5}{*}{ Женщины } & $18-59$ лет & 200 \\
\cline { 2 - 3 } & $60-74$ года & 200 \\
\cline { 2 - 3 } & Старше 75 лет & 200 \\
\hline \multirow{5}{*}{} & $11-14$ лет & 200 \\
\cline { 2 - 3 } & $15-18$ лет & 200 \\
\cline { 2 - 3 } & $18-59$ лет & 200 \\
\cline { 2 - 3 } & $60-74$ года & 200 \\
\cline { 2 - 3 } & Старше 75 лет & 200 \\
\cline { 2 - 3 } & Беременные & 200 \\
\cline { 2 - 3 } & Кормящие & 300 \\
\hline
\end{tabular}

Таблица 16

Содержание фолиевой кислоты в продуктах питания

\begin{tabular}{|l|c|}
\hline \multicolumn{1}{|c|}{ Продукт } & Содержание, мкг/100 г \\
\hline Говяжья печень & 240 \\
\hline Свиная печень & 235 \\
\hline Куриная печень & 240 \\
\hline Консервированная печень трески & 110 \\
\hline Арахис & 240 \\
\hline Кунжут & 105 \\
\hline Фасоль & 90 \\
\hline Шпинат & 80 \\
\hline Грецкий орех & 77 \\
\hline Сушеный белый гриб & 140 \\
\hline Петрушка & 110 \\
\hline Творог & 40 \\
\hline Семечки & 227 \\
\hline Пшеничная мука & 40 \\
\hline Ржаная мука & 55 \\
\hline Пшеничный хлеб с отрубями & 161 \\
\hline Семена льна & 87 \\
\hline Сырая свекла & 110 \\
\hline Куриный желток & 146 \\
\hline Зеленая спаржа & 262 \\
\hline Сушеный базилик & 310 \\
\hline Зародыши пшеницы & 281 \\
\hline Дрожжи & 550 \\
\hline
\end{tabular}




\section{Эпидемиология}

По данным литературы, недостаточное потребление фолиевой кислоты с продуктами питания в популяции женщин репродуктивного возраста достигает $91 \%$. По данным Национального института здоровья и питания США (NHANES, 2006), средний уровень потребления составляет 245 мкг/сут, что почти вдвое ниже рекомендуемой нормы (400 мкг/сут).

\section{Симптомы дефицита и избытка}

Основная причина дефицита вит. В 9 - это болезни ЖКТ, ведь значительная часть витамина синтезируется кишечной микрофлорой. Здесь же всасываются пищевые и лекарственные фолаты. При воспалительных процессах в кишечнике это всасывание будет нарушено. Кроме того, при патологии толстого кишечника страдает кишечная флора, синтезирующая фолиевую кислоту. Зачастую дефицит фолиевой кислоты отмечается после хирургических вмешательств на желудке и кишечнике. Этому же способствует прием некоторых лекарств, а также алкоголя. Поэтому признаки гиповитаминоза $\mathrm{B}_{9}$ в той или иной степени обнаруживаются у хронических алкоголиков. Заболевания печени (гепатиты, цирроз) тоже нередко осложняются недостаточностью вит. $\mathrm{B}_{9}$. Ведь именно в этом органе происходит накопление и активация фолиевой кислоты.

Уменьшению количества вит. В 9 способствуют: психоэмоциональные стрессы, перенесенные тяжелые заболевания, беременность и грудное вскармливание, период роста и полового созревания.

Типичное проявление авитаминоза $\mathrm{B}_{9}$ - это мегалобластная фолиеводефицитная анемия. Появляются общая слабость, одышка, сердцебиение. Кожа становится бледной или желтушной, а язык красным и блестящим, «лакированным». Нарушается пищеварение, возникают боль в животе, тошнота и рвота, 
диарея. Аппетит снижается. При этом пациент испытывает отвращение к мясным продуктам. Все это приводит к снижению веса и к сопутствующим обменным нарушениям. На фоне обменных нарушений развиваются психические и неврологические расстройства. Ухудшение чувствительности и движений проявляется парестезиями (покалыванием, онемением) конечностей и шаткостью походки. Пациент становится раздражительным, мышление и память ухудшаются. При тяжелом течении заболевания формируются полные параличи конечностей, появляются галлюцинации, судороги.

В настоящее время в Российской Федерации мегалобластная анемия встречается нечасто. Однако случаи гиповитаминоза $\mathrm{B}_{9}$ довольно распространены. У пациентов отмечаются те же признаки, что и при фолиеводефицитной анемии, хотя они и не столь выражены. На фоне пищеварительных и психоневрологических расстройств ухудшается внешний вид. Появляются признаки раннего старения: дряблость кожи, кожные пигментные пятна, выпадение волос.

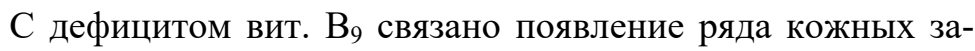
болеваний - экзем, витилиго, псориаза. Страдает сердечнососудистая система и ЦНС, возрастает опасность инфаркта миокарда и инсульта, болезни Альцгеймера.

Способность к кумуляции витамина $\mathrm{B}_{9}$ ограничена, а излишки фолатов быстро удаляются из организма. Поэтому случаи избытка фолиевой кислоты отмечаются редко, при значительной лекарственной передозировке. Суточное количество поступившей в организм фолиевой кислоты не должно превышать 1000 мкг. При поступлении 5000 мкг и выше появляются признаки гипервитаминоза: тошнота, рвота, метеоризм, повышенная возбудимость, бессонница, у эпилептиков - судорожный синдром. В случае избытка фолиевой кислоты во время беременности у детей формируется предрасположенность к простудным заболеваниям и бронхиальной астме. 


\section{Акушерские и перинатальные результаты дефицитарных состояний}

Дефицит фолатов ассоциирован с врожденными пороками развития (ВПР), включая такие дефекты нервной трубки (ДНТ), как spina bifida, анэнцефалия, менингоцеле, менингомиелоцеле, энцефалоцеле, энцефаломиелоцеле; пороками сердечно-сосудистой системы и головного мозга (не связанными с ДНТ); аномалиями конечностей и мочевыделительной системы, расщелиной верхнего нёба, омфалоцеле, а также с синдромом Дауна. Нехватка фолиевой кислоты связана с повышенным риском ПР, ПЭ и преждевременной отслойки плаценты. Отдалённые последствия фолатного дефицита у матери в преконцепционный период - это низкий индекс психического развития, когнитивные нарушения, повышенный риск возникновения онкологических заболеваний, депрессии, аутизма и шизофрении.

У мужчин приём 100 мкг фолатов в день снижает долю аномальных сперматозоидов на 3,6 \%.

На сегодняшний день влияние добавок фолиевой кислоты на риск формирования ДНТ плода, осложненного медицинскими факторами риска, включая ожирение, диабет, судорожные расстройства и терапию антагонистами фолиевой кислоты (например метотрексатом), изучено достаточно хорошо.

Потомство женщин с гестационным диабетом имеет повышенный в 2-4 раза риск развития широкого спектра врожденных дефектов. Исследования показывают, что контроль уровня глюкозы является важным методом профилактики. Кроме того, уровни микроэлементов, включая фолиевую кислоту, могут играть ключевую роль в патогенезе ДНТ и других врожденных дефектов. 


\section{Способы лабораторной диагностики}

Оценку концентрации в сыворотке крови фолиевой кислоты применяют преимущественно в диагностике анемии в комплексе с витамином $\mathrm{B}_{12}$. Запасы фолиевой кислоты в печени относительно невелики, в связи с чем её дефицит может развиться в течение одного месяца после прекращения её поступления, а анемия - через 4 месяца. Диагностика проводится хемилюминесцентным иммуноанализом на микрочастицах (сыворотка крови). Референсные значения: 3,1-20,5 нг/мл.

\section{Варианты коррекции}

Фолиевая кислота выпускается в виде таблеток массой 1 мг. Есть также фолацин - таблетки в дозе 5 мг.

Показания к применению: различные виды анемий, сердечно-сосудистые заболевания, сопровождающиеся атеросклерозом, сахарный диабет, болезни ЖКТ, протекающие по типу гастритов, энтеритов и колитов, заболевания печени - вирусные и хронические гепатиты, цирроз, некоторые виды интоксикаций, туберкулез, кожные заболевания, эпилепсия, болезнь Альцгеймера, экзема, псориаз и другие кожные заболевания, восстановительный период после перенесенных тяжелых заболеваний, детский и юношеский возраст.

Синтетическая фолиевая кислота усваивается гораздо хуже, чем натуральная. Поэтому постоянно идет поиск новых лекарственных форм с максимальной биодоступностью. Витамин $\mathrm{B}_{9}$ включен в состав многих комбинированных средств, среди которых «Алфавит», «Компливит», «Доппельгерц», «Витрум». За рубежом разработаны препараты фолиевой кислоты, предназначенные специально для беременных - «Метафолин», «Мамифол». В России таким средством является, например, «9 месяцев. Фолиевая кислота». Это таблетки с дозировкой 0,4 мг. При исходном отсутствии гиповитаминоза $\mathrm{B}_{9}$ данного 
количества вполне достаточно для физиологического течения беременности и рождения здорового ребенка. Фолиевую кислоту следует принимать заранее, на этапе прегравидарной подготовки, за 2-3 месяца до ее наступления. Прием продолжают вплоть до самих родов и далее при грудном вскармливании.

Для определения адекватной дозы фолатов во время беременности необходимо оценить степень риска развития фолатзависимых аномалий развития плода.

Выделяют три группы риска:

I. Группа низкого риска. Женщины и мужчины без указания на фолатзависимые состояния в личном и семейном анамнезе.

II. Группа умеренного риска. Женщины и мужчины, для которых верно хотя бы одно из следующих утверждений.

- наличие фолатзависимых аномалий развития (ВПС, мочевых путей, конечностей, орофациальных дефектов, врождённой гидроцефалии, но не ДНТ) в личном или семейном анамнезе;

- ДНТ у родственников 2-й степени родства;

- алиментарные ограничения.

\section{III. Группа высокого риска:}

- наличие ДНТ в личном анамнезе либо выявление ДНТ при предыдущих беременностях;

- ДНТ у родственников 1-й степени родства;

- приём препаратов с тератогенным действием (карбамазепин, вальпроевая кислота, фенитоин, фенобарбитал, метотрексат, триамтерен, триметоприм, колестирамин и др.);

- синдром мальабсорбции (болезнь Крона, целиакия, желудочное анастомозирование, выраженные заболевания печени, диализ, алкоголизм);

- СД 1-го или 2-го типов;

- ожирение;

- мутации гена 5-метилтетрагидрофолатредуктазы (MTHFR). 
Рекомендованные суточные дозы фолатов составляют: в группе низкого риска - 400 мкг/сут, умеренного риска - до 1000 мкг/сут, высокого риска - до 4000-5000 мкг/сут.

Согласно рекомендациям ВО3, с начала попыток зачатия и до 12 недель беременности женщины должны получать 400 мкг фолиевой кислоты в день; кроме того, есть данные, что профилактическая концентрация фолиевой кислоты в крови может быть достигнута за 4 недели при дотации 800 мкг в сутки. FIGO рекомендует более высокие дозы препарата (до 5000 мкг в сутки) женщинам из групп риска, а пациенткам с полиморфизмом гена MTHFR может быть назначен L-метилфолат. B то же время в систематическом обзоре (2019) показано, что выводы о лучшей биодоступности L-метилфолата в общей популяции неоднозначны.

\section{Взаимодействие с другими веществами}

На способности вызывать авитаминоз $\mathrm{B}_{9}$ основывается действие некоторых противоопухолевых препаратов, в частности метотрексата. Снижая количество фолиевой кислоты в опухолевых клетках, он замедляет их деление. Однако это приводит к авитаминозу $\mathrm{B}_{9}$ в здоровых тканях и к развитию соответствующих побочных эффектов. Витамин С способствует сохранению вит. $\mathrm{B}_{9}$ в тканях, а вит. В9 облегчает усваивание вит. $\mathrm{B}_{4}$. Поэтому комбинация этих витаминов желательна.

Также вит. $\mathrm{B}_{9}$ совместим с вит. $\mathrm{B}_{2}$ (рибофлавином), вит. $\mathrm{B}_{7}$ (биотином) и с железом. Витамин $\mathrm{B}_{12}$ (цианокобаламин) способствует всасыванию и усиливает действие вит. В9. Однако массивное поступление вит. В 9 приводит к снижению количества вит. $\mathrm{B}_{12}$.

Сочетание фолиевой кислоты и цинка нежелательно, так как вместе они образуют нерастворимый комплекс. По некоторым данным фолиевая кислота замедляет всасывание магния. 


\section{9. ВИТАМИН В 12 (ЦИАНОКОБАЛАМИН)}

Открытие цианокобаламина, как и многих других витаминов, в буквальном смысле продиктовано жизнью. В ХІХ в. врачами Аддисоном и Бирмером среди множества заболеваний была выделена особая форма анемии. Данную болезнь так и назвали анемией Аддисона - Бирмера. Заболевание не было распространено, но протекало крайне тяжело и практически всегда заканчивалось гибелью больного, поэтому болезнь Аддисона - Бирмера еще называют пернициозной, или злокачественной анемией, тем самым подчеркивая ее крайне неблагоприятное течение. В 20-х гг. прошлого века американский ученый врач Уиппл исследовал эффективность ряда пищевых продуктов для лечения искусственной вызванной пернициозной анемии у подопытных собак. Когда собакам в рацион добавляли сырую печень, их состояние улучшалось, и, как правило, они выздоравливали. Ученый пришел к логичному выводу, что в печени есть некое вещество, оказывающее антианемическое действие. Первоначально таким веществом считали железо, так как уже тогда была изучена связь этого элемента с кроветворением. Однако само по себе железо не всегда способно устранить анемию. Поэтому помимо него должен быть еще некий фактор, оказывающий антианемическое действие. И этот фактор содержится в соке или в мякоти печени, которую и давали пациентам в сыром виде. Однако прием большого количества сырой печени, пусть даже и с лечебной целью, вызывал вполне естественное отвращение. Необходимо было выделить вещество в максимально очищенном виде. Первый шаг в этом направлении был сделан в 1928 г., когда был получен печеночный экстракт, по своей антианемической эффективности в 100 раз превосходивший натуральное сырье, т.е. печень. Новый препарат для приема внутрь назвали гепатокрином. В ходе дальнейшей очистки от балластных веществ на ос- 
нове гепатокрина была синтезирована инъекционная форма лекарства - гепалон. Но все эти препараты получали из говяжьей печени, и это сильно ограничивало его массовое производство. В 1950 г. отрыли способ получения препарата из бактерий, что позволило расширить и удешевить производство. А двумя годами раньше, в 1948 г., вещество было получено в виде очищенных кристаллов. Тогда же его и назвали цианокобаламином или вит. В В $_{12}$ В 1955 г. была определена молекулярная структура цианокобаламина, а в 1973 г. ученые разработали метод синтетического производства этого витамина. Уиппл и многие другие ученые, которые в разное время внесли вклад в изучение цианокобаламина, были удостоены Нобелевской премии.

Среди других витаминов вит. $\mathrm{B}_{12}$ является своего рода уникальным химическим соединением. Молекулы других витаминов лишены ионов металла, а в молекулах вит. $\mathrm{B}_{12}$ металл есть. И этот металл - кобальт. Молекулярная структура вит. $\mathrm{B}_{12}$ довольно сложна. Ее основным структурным элементом является громоздкое корриновое кольцо с ионом кобальта в центре. Ковалентная связь между металлом и углеродом больше не встречается ни в одном из природных соединений. В принципе, вит. $\mathrm{B}_{12}$ правильно было бы называть кобаламином. Но ион кобальта в корриновом кольце имеет одну свободную связь, к которой присоединяются различные химические группы.

В зависимости от этих присоединившихся групп существуют четыре варианта кобаламинов: цианокобаламин - связь кобальта с цианогруппой, гидроксикобаламин - с гидроксильной группой, метилкобаламин - с метильным остатком, 5'-дезоксиаденозилкобадамин (аденозилкобаламин, кобамид) с 5'-дезоксиаденозильным остатком. Все эти вещества со сходной химической структурой, обладающие одними и теми же витаминными свойствами, именуют витамерами. Микроорганизмы синтезируют вит. $\mathrm{B}_{12}$ в виде витамера гидроксикобаламина. Цианокобаламин - это полусинтетический вариант вит. В12. Его получают из бактериального гидроксикобаламина или синтези- 
руют химическим путем. Однако ни цианокобаламин, ни гидроксикобаламин не являются биологически активными соединениями. В организме они трансформируются в активные витамеры - метилкобаламин и аденозилкобаламин. Эти соединения являются кофакторами или коферментами, небелковыми составными частями ферментных систем. В роли коферментов они участвуют в кроветворении и других важнейших физиологических процессах.

Наибольшее количество вит. $\mathrm{B}_{12}$ мы получаем в виде цианокобаламина. Поэтому за витамином закрепилось именно это название. В данном случае цианокобаламин можно рассматривать как собирательный термин, объединяющий в себе другие витамеры $\mathrm{B}_{12}$. Если рассматривать цианокобаламин в виде конкретного химического соединения, то это вещество с номенклатурным названием альфа-(5,6-диметилбензимидазолил)кобамид цианид имеет химическую формулу $\mathrm{C}_{63} \mathrm{H}_{88} \mathrm{CoN}_{14} \mathrm{O}_{14} \mathrm{P}$. Оно представляет собой ярко-красные кристаллы без запаха. Хорошо растворяется в воде, и раствор, в зависимости от концентрации, тоже имеет красный или розовый цвет. И это еще одна причина, по которой цианокобаламин называют красным витамином. Характерный красный окрас обусловлен атомами кобальта. Цианокобаламин устойчив к действию света и к нагреванию. Его температура плавления довольно высока $-3000{ }^{\circ} \mathrm{C}$. Однако различные окислители и восстановители, соли тяжелых металлов инактивируют цианокобаламин. То же самое происходит под действием некоторых микроорганизмов. Сходными физическими свойствами обладают и другие представители семейства кобаламинов.

\section{Основы метаболизма}

При попадании в желудок пищевой или лекарственный цианокобаламин соединяется с внутренним фактором Кастла желудочного сока. Только в таком связанном виде он распознается рецепторным аппаратом энтероцитов (клеток слизистой 
оболочки тонкого кишечника), а затем всасывается. Однако, по имеющимся сведениям, при поступлении в ЖКТ в дозе свыше 200 мкг лекарственный цианокобаламин может всасываться и без внутреннего фактора Кастла. Всосавшийся комплекс вит. $\mathrm{B}_{12}$ внутренний фактор - поступает в систему воротной вены печени. Далее он соединяется со специфическим белком-переносчиком и в таком виде доставляется с кровью в ткани. Здесь он высвобождается и трансформируется в активные формы (метилкобаламин и 51-дезоксиаденозилкобаламин), которые и принимают участие в обменных процессах. После этого некоторое количество вит. $\mathrm{B}_{12}$ выводится из организма с желчью через кишечник и с мочой через почки. Однако, несмотря на то что цианокобаламин является водорастворимым, он может кумулировать, накапливаться в организме. Некоторое количество витамина кумулируется в тканях внутренних органов (легкие, почки, селезенка). Но больше всего его накапливает печень.

\section{Физиологические функции}

- Система кроветворения. Витамин $\mathrm{B}_{12}$ называют внешним фактором Кастла (в других источниках - Кастля). Внутренний фактор Кастла представляет собой гликомукопротеид, белковое соединение, фермент, образующийся из пепсиногена желудочного сока под действием соляной кислоты. Факторы Кастла, внешний и внутренний, играют большую роль в кроветворении. Они стимулируют эритропоэз, образование эритроцитов в костном мозге. Благодаря вит. $\mathrm{B}_{12}$ образуются эритроциты правильного размера и двояковогнутой формы. Такие эритроциты медленнее разрушаются и дольше живут. Витамин $\mathrm{B}_{12}$ также стимулирует синтез гемоглобина. Все это приводит к тому, что полноценные эритроциты вместе с кровью доставляют к тканям необходимое количество кислорода, а в обратном направлении транспортируют углекислоту. 
- Дыхательная система. Благодаря повышению качества доставки кислорода мы легче переносим гипоксию. Одышка при физических нагрузках или других состояниях, сопровождающихся усиленным расходом кислорода, минимальна или не развивается вовсе. В том, что мы можем задержать дыхание на некоторое время без ущерба для здоровья, есть частичная заслуга вит. $\mathrm{B}_{12}$. Этот витамин помогает легче переносить заболевания, сопровождающиеся хронической дыхательной недостаточностью (бронхиальная астма, хронические обструктивные заболевания легких).

- Иммунная система. Наряду с эритроцитами цианокобаламин стимулирует синтез лейкоцитов. Благодаря этому укрепляется иммунитет, повышается устойчивость к различным видам бактериальных, вирусных и грибковых инфекций.

- Сердечно-сосудистая система. Стимулируя кроветворение, цианокобаламин оказывает мягкое гипертензивное действие, незначительно повышает АД. К гипертонической болезни это не приводит, но играет позитивную роль при гипотонии. При качественной доставке кислорода к сердечной мышце предупреждаются ее дистрофические и склеротические изменения. Под действием цианокобаламина снижается риск развития таких патологических состояний, как миокардиодистрофия, кардиосклероз, ИБС с исходом в инфаркт миокарда. Витамин снижает уровень гомоцистеина. Также вит. В 12 оказывает антиатеросклеротическое действие. Он снижает уровень Х-ЛПНП в плазме крови, препятствует образованию атеросклеротических бляшек, и это дополнительно улучшает доставку кислорода к тканям.

- Нервная система. Антиатеросклеротические действие со стороны ЦНС проявляется улучшением мозгового кровообращения. Но этим влияние вит. $\mathrm{B}_{12}$ на состояние нервной системы не ограничивается. Под действием цианокобаламина повышается количество янтарной кислоты, одного из компонентов 
миелиновой оболочки нервных волокон. Эта оболочка обеспечивает проведение двигательных и чувствительных импульсов по нервным волокнам. Цианокобаламин участвует в синтезе холина, также известного как вит. $\mathrm{B}_{4}$. Из холина образуется ацетилхолин - нейромедиатор, обеспечивающий передачу нервных импульсов через синапсы, контакты между телами и отростками нейронов. Помимо этого, вит. $\mathrm{B}_{12}$ стимулирует синтез мелатонина. Этот гормон шишковидного тела (эпифиза) формирует суточные ритмы с правильным чередованием сна и бодрствования. Витамин $\mathrm{B}_{12}$ стимулирует другие виды обмена веществ в ЦНС и в периферических нервах. Это приводит к улучшению памяти, мыслительных способностей, повышает устойчивость к психоэмоциональным стрессам, а в старческом возрасте предотвращает развитие болезни Альцгеймера.

- Костно-мышечная система. На белковый обмен вит. $\mathrm{B}_{12}$ оказывает анаболическое действие, т.е. способствует синтезу белковых соединений из аминокислот. Растет мышечная масса, повышается физическая выносливость. Этому же способствует улучшение доставки кислорода к мышечной ткани. Согласно некоторым данным, вит. $\mathrm{B}_{12}$ обеспечивает рост остей в длину и повышает их прочность.

- ЖКТ. Цианокобаламин стимулирует ферментативную активность печени, препятствует жировой инфильтрации этого органа. Также улучшает секреторную функцию поджелудочной железы, тонкого кишечника. Повышается аппетит, становится более качественным расщепление и всасывание компонентов пищи.

- Мочевыделительная система. Предотвращает дистрофические изменения в почечной ткани. 


\section{Содержание в продуктах, суточная потребность}

Ни растения, ни животные, ни человек не в состоянии самостоятельно синтезировать вит. В 12 . Его синтезируют лишь некоторые группы бактерий, обитающих в почве и в толстом кишечнике человека и животных. Растения в некоторой степени накапливают вит. $\mathrm{B}_{12}$, поступающий из почвы. Животные получают вит. $\mathrm{B}_{12}$ частично из растений в составе кормов, а частью их синтезирует собственная кишечная микрофлора (табл. 17, 18).

\section{Таблица 17}

Рекомендуемые нормы потребления витамина $\mathrm{B}_{12}$

\begin{tabular}{|l|c|}
\hline \multicolumn{1}{|c|}{ Категория } & Суточная норма, мкг \\
\hline Младенцы до 6 мес. & 0,4 \\
\hline Младенцы 7-12 мес. & 0,5 \\
\hline Дети 1-3 лет & 0,9 \\
\hline Дети 4-8 лет & 1,2 \\
\hline Дети 9-13 лет & 1,8 \\
\hline Подростки старше 14 лет и взрослые & 2,4 \\
\hline Беременные & 2,6 \\
\hline Кормящие & 2,8 \\
\hline
\end{tabular}

Таблица 18

Содержание витамина $\mathrm{B}_{12}$ в продуктах питания:

\begin{tabular}{|l|c|}
\hline \multicolumn{1}{|c|}{ Продукт } & Содержание, мкг $/ 100$ г \\
\hline Печень говяжья & 60 \\
\hline Почки говяжьи & 25 \\
\hline Печень свиная & 30 \\
\hline Печень куриная & 16 \\
\hline говядина & 3 \\
\hline Молоко и сметана & 0,4 \\
\hline Твердые сорта сыра & $1,05-2,2$ \\
\hline Творог & 1,32 \\
\hline Яйца & 1,95 \\
\hline Мидии & 12 \\
\hline Креветки & 1,1 \\
\hline
\end{tabular}


Окончание табл. 18

\begin{tabular}{|l|c|}
\hline \multicolumn{1}{|c|}{ Продукт } & Содержание, мкг/100 г \\
\hline Скумбрия & 12 \\
\hline Сардина & 11 \\
\hline Сельдь & 10 \\
\hline Осьминог & 20 \\
\hline Морской окунь & 2,4 \\
\hline
\end{tabular}

\section{Эпидемиология}

Распространенность анемии Аддисона - Бирмера невелика, не более $1 \%$, и увеличивается в пожилом возрасте. Гиповитаминоз вит. $\mathrm{B}_{12}$ не такое уж редкое явление. Он наблюдается примерно у 40 \% населения, хотя в большинстве случаев протекает не столь тяжело, как пернициозная анемия.

\section{Симптомы дефицита и избытка}

Типичное проявление авитаминоза $\mathrm{B}_{12}$ - злокачественное малокровие, анемия Аддисона - Бирмера. Механизм, или патогенез, заболевания заключается в нарушении клеточного деления вследствие появления измененных форм ДНК. Из-за этого нарушается созревание и дифференцировка эритроцитов. В костном мозге появляются крупные незрелые формы эритроцитов - мегалобласты. Патологически измененные эритроциты обнаруживаются и в периферической крови. Данное заболевание протекает со всеми симптомами, присущими анемиям: с общей слабостью, бледностью кожи, головокружением, а также нарушениями в других системах органов. При этом общего истощения (кахексии) может и не быть. Без заместительной терапии цианокобаламином заболевание в большинстве случаев заканчивается фатально.

Патологические изменения при гиповитаминозе $\mathrm{B}_{12}$ могут проявляться в виде нарушения всех важнейших систем и органов. 
- Нервная система. Из-за нарушения синтеза миелиновой оболочки нервные волокна подвергаются демиелинизации, что проявляется неврологическими расстройствами. Снижается кожная и мышечная чувствительность, появляются парестезии в виде онемения, жжения, ползания мурашек. Замедляются мыслительные способности, ухудшается память, способность концентрировать внимание. Пациенты жалуются на головную боль, головокружение, ощущение шума в ушах. Появляется раздражительность, депрессия, нарушается сон. В особо тяжелых случаях отмечается психоз с галлюцинациями.

- Иммунная система. С низким иммунитетом при дефиците витамина $\mathrm{B}_{12}$ связывают повышенный риск развития некоторых видов злокачественных опухолей. Так, у женщин гиповитаминоз $\mathrm{B}_{12}$ - одна из причин рака молочных желез.

- ЖКТ. Со стороны желудка отмечается сниженная или нулевая кислотность желудочного сока (ахилия), развивается гастродуоденит. Возможно язвообразование в желудке и в двенадцатиперстной кишке. Негативные изменения в печени приводят к нарушению образования желчи. Ухудшается всасывание пищи в кишечнике. Аппетит снижен или полностью отсутствует, появляются боли и вздутие живота, частые запоры, иногда сменяющиеся диареей.

- Дыхательная система. Возникает одышка даже при незначительной физической нагрузке, а иногда и в покое. Дыхательная недостаточность усугубляется частыми воспалительными процессами в бронхолегочном дереве (бронхиты, пневмонии) из-за снижения иммунной защиты организма.

- Сердечно-сосудистая система. На фоне гипоксии с одышкой компенсаторно развивается тахикардия, которая сочетается с гипотонией. Формируется кардиосклероз, ИБС с осложнениями в виде инфаркта миокарда, нарушений ритма и сердечной недостаточности.

- Опорно-двигательная система. Атрофия мышц со снижением мышечной силы и выносливости. В сочетании с нев- 
рологическими расстройствами это приводит к формированию контрактур, стойких двигательных ограничений.

- Кожа и ее производные. Ломкость и выпадение волос. Сухая себорея волосистой части головы. Бледность и желтушный оттенок кожи, изъязвления в полости рта, ярко-красный «лакированный» язык.

- Мочевыделительная система. Нарушение выделительной функции почек. При выраженном авитаминозе из-за паралича мышц-сфинктеров развивается недержание мочи с дальнейшими инфекционно-воспалительными процессами в мочевыделительной системе.

- Органы зрения. Ухудшение зрения, катаракта, слезотечение, покраснение глаз, светобоязнь.

Витамин $\mathrm{B}_{12}$, внешний фактор Кастла, может всасываться только в комплексе с внутренним фактором Кастла. При патологии ЖКТ синтез этого гликопротеида в желудке может быть нарушен. Среди конкретных причин:

- язвенная болезнь желудка;

- гастрит;

- атрофический и аутоиммунный рак желудка;

- хирургические вмешательства на желудке по поводу его полного или частичного удаления при язвенной болезни, раке;

- некоторые генетические аномалии, при которых внутренний фактор Кастла отсутствует или синтезируется в малом количестве;

- то же самое будет отмечаться при нарушении всасывания вит. $\mathrm{B}_{12}$ в результате воспалительных заболеваний, опухолей тонкого кишечника, операций на тонком кишечнике;

- в редких случаях к дефициту вит. $\mathrm{B}_{12}$ приводят некоторые генетически обусловленные аномалии, при которых тканевая и клеточная утилизация цианокобаламина будет затруднена.

При всех описанных выше ситуациях даже нормальное или избыточное поступление в организм вит. $\mathrm{B}_{12}$ будет сопровождаться его дефицитом. 
Отдельно следует отметить факторы, которые повышают расход или способствуют разрушению вит. В $_{12}$ и тем самым формируют его дефицит: физические нагрузки, психоэмоциональные стрессы, курение, злоупотребление алкоголем, некоторые лекарственные препараты, печеночная недостаточность и цирроз печени, почечная недостаточность, период бурного роста и полового созревания, беременность и грудное вскармливание, глистные инвазии, тиреотоксикоз, сахарный диабет, подагра, туберкулез, любые злокачественные опухоли, не обязательно локализующиеся в ЖКТ.

Нетрудно заметить, что некоторые из заболеваний, например болезни ЖКТ, могут быть одновременно и причинами, и следствием авитаминоза $\mathrm{B}_{12}$. При этом формируется порочный круг обменных нарушений, которые взаимно отягощают друг друга.

Несмотря на способность к кумуляции, в большом количестве поступающий с пищей вит. $\mathrm{B}_{12}$ накапливаться не может. Редкие случаи гипервитаминоза $\mathrm{B}_{12}$ в основном отмечаются у пожилых людей при хронической передозировке лекарственных форм цианокобаламина. При этом развиваются следующие симптомы: повышенная психическая возбудимость, крапивница и акне (угревая сыпь), тромбоз периферических сосудов из-за усиления свертываемости крови, сердечная недостаточность с застойными явлениями во внутренних органах. При подтвержденном лабораторными анализами гипервитаминозе $\mathrm{B}_{12}$ необходимо срочно отменить все препараты, содержащие этот витамин, и перейти на растительную пищу.

\section{Участие в репродукции}

У женщин улучшение кровообращения в матке и придатках в некоторой степени предупреждает воспалительные процессы в этих органах. Витамин $\mathrm{B}_{12}$ играет большую роль в процессе овуляции, поэтому необходим для наступления беремен- 
ности. Недостаток может привести либо к отсутствию овуляции, либо к прекращению развития оплодотворенной яйцеклетки, что ведет к выкидышу на ранней стадии беременности. Есть данные, что терапия вит. $\mathrm{B}_{12}$ во многих случаях увеличивает вероятность успешного зачатия. Женщины, которые испытывают нехватку вит. $\mathrm{B}_{12}$, имеют повышенный риск бесплодия и повторяющихся выкидышей.

У мужчин вит. $\mathrm{B}_{12}$ обеспечивает созревание сперматозоидов и способность спермы к оплодотворению. У обоих полов цианокобаламин как регулятор синтеза нуклеиновых кислот формирует правильный набор хромосом в сперматозоидах и яйцеклетках и предотвращает возникновение генетических аномалий у потомства.

\section{Акушерские и перинатальные результаты дефицитарных состояний}

С гиповитаминозом $\mathrm{B}_{12}$ может быть ассоциировано мужское и женское бесплодие, у женщин - частые выкидыши, осложнения в родах. Повышается риск генетических аномалий у будущего ребенка.

\section{Способы лабораторной диагностики}

Определение $\mathrm{B}_{12}$ проводят в сыворотке крови хемилюминесцентным иммуноанализом на микрочастицах (CMIA). В ряде опубликованных исследований утверждается, что голотранскобаламин является лучшим индикатором статуса вит. $\mathrm{B}_{12}$, чем общий кобаламин в сыворотке крови. Около $50 \%$ пациентов с субклиническим дефицитом $\mathrm{B}_{12}$ имеют нормальный уровень общего $\mathrm{B}_{12}$. Установлено, что при истощении депо $\mathrm{B}_{12}$ уровень активного $\mathrm{B}_{12}$ снижается в крови раньше, чем снижается уровень общего $\mathrm{B}_{12}$. Концентрация голотранскобаламина является 
отражением статуса вит. $\mathrm{B}_{12}$, независимо от недавнего потребления витамина.

Референсные значения: 25,0-165,0 пмоль/л (для возраста 18-65 лет).

\section{Варианты коррекции}

В клинической практике наряду с цианокобаламином используют оксикобаламин с действующим веществом гидроксикобаламином. Препараты (цианокобаламин, оксикобаламин) представлены ампулами с 0,05\%-ным и 0,02\%-ным раствором для внутримышечных и внутривенных инъекций. В таблетированных формах для приема внутрь содержится до 100 мкг цианокобаламина.

Считается, что этого количества вполне достаточно для обеспечения суточной дозы витамина. При назначении препарата следует учитывать, что при заболеваниях ЖКТ и многих видах обменных нарушений всасывание принятого внутрь вит. $\mathrm{B}_{12}$ может быть сведено к минимуму, в то время как при инъекционном введении все его количество поступает в организм. Зарубежные комбинированные препараты для приема внутрь («Нейровитан», «Нейробион») содержат несколько большее количество цианокобаламина (250 и 240 мкг соответственно). Американские производители БАД Solgar и Nowfoods проблему всасывания вит. $\mathrm{B}_{12}$ решили по-своему. Они выпустили комбинированные препараты для рассасывания, содержащие до 1000 и 5000 мкг этого витамина. Всасывание в полости рта в этих дозировках тоже восполняет суточную потребность в витамине. Витамин $\mathrm{B}_{12}$ входит в состав многих других мультивитаминных комплексных средств («Мильгамма», «Тригамма», «Компливит», «Пентовит» и др.). 


\section{Взаимодействие с другими веществами}

Некоторые из лекарств способствуют формированию дефицита витамина $\mathrm{B}_{12}$ : снотворные, слабительные, антикоагулянты, противотуберкулезные средства, антациды, антибиотики.

Соли калия уменьшают запасы вит. $\mathrm{B}_{12}$ в тканях. Железо и медь инактивируют цианокобаламин, а кальций, напротив, делает его активным.

Сочетание вит. $\mathrm{B}_{12}$ со многими другими витаминами нежелательно. Витамин С может ухудшать адсорбцию вит. $\mathrm{B}_{12}$ из пищевых продуктов. Кобальт, содержащийся в цианокобаламине, действует разрушающе на многие другие витамины группы В (вит. $\mathrm{B}_{1}, \mathrm{~B}_{2}, \mathrm{~B}_{3}, \mathrm{~B}_{5} ; \mathrm{B}_{6}$ ). В то же время он активирует вит. $\mathrm{B}_{9}$ (фолиевую кислоту) и облегчает ее всасывание, что делает комбинацию этих витаминов желательной. Но при этом следует учитывать, что прием фолиевой кислоты также приводит к снижению количества вит. $\mathrm{B}_{12}$. 


\section{0. ПОЛИНЕНАСЫЩЕННЫЕ ЖИРНЫЕ кИслОтЫ (ПНЖК)}

Жирные кислоты (ЖК) входят в состав всех животных и растительных жиров. По степени насыщенности атомами водорода углеродной цепи ЖК подразделяются на насыщенные, мононенасыщенные и полиненасыщенные. В насыщенных ЖК (лауриновая кислота (С12:0), миристиновая кислота (С14:), пальмитиновая кислота (С16:0), стеариновая кислота (С18:0)) атомы углерода соединены одинарными ковалентными связями, остальные две связи замещены атомами водорода. Насыщенные ЖК имеют твердую консистенцию за счет вытянутых цепей вдоль прямой линии и плотного прилегания друг к другу, вследствие чего повышается температура их плавления. Необходимы организму в небольших количествах (6-10 \% от общей калорийности суточного рациона). Наибольшее количество насыщенных ЖК содержат сливочное, кокосовое масла и масло какао. Избыточное потребление насыщенных жиров способствует повышению в крови уровня общего холестерина (миристиновая кислота обладает максимальным холестерин повышающим действием) и Х-ЛПНП, что приводит к развитию сердечно-сосудистых заболеваний.

Мононенасыщенные ЖК (МНЖК) имеют одну двойную связь (олеиновая кислота (18:1, омега-9), миристолеиновая, пальмитолеиновая кислоты), участвуют в синтезе запасных и структурных липидов и содержатся практически во всех жирах. Растительные масла, богатые МНЖК, способствуют снижению Х-ЛПНП в крови, а также удобны для технологических процессов ввиду низкой скорости окисления.

Полиненасыщенные ЖК (ПНЖК) имеют несколько двойных связей и различаются по месту расположения первой двойной связи от концевой метильной группы: 
1. Омега-3 или n-3 (двойная связь у 3-го атома углерода):

- $\alpha$-линоленовая (C18:3n-3);

- эйкозапентаеновая (С20:5n-3) - ЭПК;

- докозагексаеновая (C22:6n-3) - ДГК.

2. Омега-6 или n-6 (двойная связь у 6-го атома углерода):

- линолевая (C18:2n-6);

- арахидоновая (С20:4n-6);

- гамма-линоленовая (C18:3n-6);

- эйкозадиеновая (C20:2n-6).

Линолевая, арахидоновая, $\alpha$-линоленовая кислоты, ЭПК и ДГК являются наиболее важными ПНЖК для человеческого организма.

Ряд ПНЖК не синтезируются в организме человека и являются незаменимыми. Например, линолевая кислота - основная омега-6 ПНЖК растительных жиров. В организме человека ее метаболиты участвуют в образовании биологически активных веществ (тромбоксана А2, простагландинов и лейкотриенов), которые способствуют тромбообразованию и появлению воспалительных процессов.

В середине 70-х гг. ХХв. внимание ученых привлек тот факт, что у эскимосов Гренландии смертность от инфаркта миокарда в 10 раз ниже, чем у жителей Дании и Северной Америки. В ходе исследований выяснилось, что эскимосы употребляли в пищу продукты (мясо морских животных), содержащие омега-3 ПНЖК, в 5-10 раз чаще. Дальнейшие исследования подтвердили потенциально антиатерогенный эффект омега-3 ПНЖК.

\section{Метаболизм}

По химической структуре жирные кислоты относятся к органическим карбоновым кислотам, содержащим от 12 до 24 углеродных атомов. В организме человека ЖК состоят из цепи углеродных ( $\geq 16)$ атомов и находятся в свободном состоянии (в клетках и тканях), в плазме крови (в комплексе с альбуми- 
ном) или входят в состав липидов: ТГ, фосфолипидов (ФЛ), эфиров холестерина (ХC), образуя эфирную связь с их спиртовыми группами. ТГ являются самым богатым источником энергии, ФЛ - основной компонент всех клеточных мембран, эфиры ХC - форма запаса ХC в клетках. ХC, в свою очередь, необходим для синтеза стероидных гормонов. ЖК не растворимы в водных средах.

Высвобождение ЖК из жиров пищи и абсорбция происходят в тонком кишечнике путем гидролиза (ТГ и ФЛ) при участии ферментов поджелудочной железы. Соли желчных кислот обеспечивают включение ЖК и в смешанные, устойчивые к водной среде мицеллы с гидрофобным ядром, которые переносятся к поверхности тонкого кишечника. Биодоступность ЖК в физиологических условиях составляет 85-95\%.

Простейшим представителем омега-3 ПНЖК является $\alpha$-линоленовая кислота. В процессе пролонгации в организме человека из нее синтезируются длинноцепочечные омега-3 ПНЖК: эйкозапентаеновая кислота (ЭПК) и декозогексаеновая кислота (ДГК). Они играют значительную роль в регуляции уровня липидов, тромбообразовании, вазодилатации, воспалении.

У растений имеется особый фермент дельта-15-десатураза, синтезирующий $\alpha$-линоленовую кислоту из линолевой кислоты. Животные и люди не обладают этим ферментом, не способны к синтезу $\alpha$-линоленовой кислоты, поэтому для них она является незаменимой. В дальнейшем $\alpha$-линоленовая кислота метаболизируется путем десатурации и удлинения. Десатурация происходит у атомов углерода ниже 9 (считая от углерода карбоксильной группы) и в основном происходит в печени. $\alpha$-линоленовая кислота с помощью фермента дельта-6-десатуразы преобразуется в стеаридоновую кислоту (18:4n-3), стеаридоновая кислота удлиняется до эйкозатетраеновой кислоты (20:4n-3), а та, в свою очередь, под воздействием фермента дельта-5-десатуразы преобразуется в ЭПК. Превращение ЭПК в ДГК включает этап добавления двух атомов углерода с образо- 
ванием докозапентаеновой кислоты (ДПК; 22:5n-3), и далее добавление еще двух атомов углерода для получения ДГК. Таким образом, $\alpha$-линоленовая кислота является предшественником ЭПК и ДГК. Кроме того, существует путь обратного превращения ДГК в ЭПК.

За счет повышенного содержания эстрогенов в организме у женщин эволюционно сформировалась более высокая, чем у мужчин, способность превращения $\alpha$-линоленовой кислоты в ЭПК и ДГК. Синтез длинноцепочечных омега-3 ПНЖК у человека происходит очень медленно, а при старении организма и некоторых болезнях замедляется и полностью теряется способность синтезировать ЭПК и ДГК из $\alpha$-линоленовой кислоты вследствие снижения активности фермента десатуразы на 50 \% и более.

\section{Физиологические функции}

Биологическая роль ПНЖК определяется двумя их главными функциями - структурной и метаболической. ПНЖК являются ключевыми структурными компонентами ФЛ клеточных и внутриклеточных мембран. Метаболическая роль в большей степени определяется разнообразием биологически активных веществ, образующихся в процессе их метаболизма.

Исследования L.Costantini (2017) показали положительное влияние омега-3 на микробиоту кишечника, в частности уменьшение Faecalibacterium, часто связанное с увеличением Bacteroidetes и бактерий, принадлежащих к семейству Lachnospiraceae.

Липиды составляют около $60 \%$ сухого вещества мозга. В составе серого вещества головного мозга основные липиды составляют примерно следующее соотношение: $25 \%$ - стеариновая кислота, 25 \% - ДГК, $14 \%$ - арахидоновая кислота, $12 \%$ олеиновая кислота. В ФЛ мембран сетчатки глаза наибольший процент составляет ДГК (около 60 \%). 
Физиологические функции ПНЖК:

1. Нормализация липидного обмена:

- уменьшение синтеза ТГ, Х-ЛПОНП и аполипопротеина в печени;

- повышение уровня Х-ЛПВП;

- увеличение экскреции желчных кислот (продуктов катаболизма ХC) с кишечным содержимым.

2. Антиатеротромбогенная функция:

- повышение уровня тканевого активатора плазминогена;

- снижение активности его ингибитора;

- увеличение фибринолитической активности;

- снижение вазоспастического ответа на действие катехоламинов;

- увеличение эндотелийзависимой релаксации коронарных артерий в ответ на действие брадикинина, серотонина, аденозин дифосфата и тромбина).

3. Противовоспалительный эффект:

- ингибирование хемотаксиса лейкоцитов;

- уменьшение адгезии лейкоцитов и эндотелиальных клеток;

- снижение выработки арахидоновой кислоты, содержащей эндоканнабиноиды;

- снижение выработки воспалительных цитокинов, снижение реактивности Т-клеток;

- регуляция выработки эйкозаноидов. Важно отметить, что противовоспалительные эйкозаноиды, происходящие из омега-3, препятствуют действию провоспалительных омега-6 эйкозаноидов или имеют аналогичное, но намного менее сильное действие.

4. Мембраностабилизирующее действие (частичное замещение арахидоновой кислоты на ЭПК и ДГК в мембранах клеток, влияние на проницаемость и текучесть клеточных мембран, активность мембранно-связаных ферментов и транспортных белков). 
5. Обеспечение направленности иммунного ответа - продукция различных групп эйкозаноидов (простагландинов, лейкотриенов), изменение экспрессии генов как результат влияния жирных кислот на факторы транскрипции, известные как PPARs (peroxisome proliferatoractivated receptors).

ПНЖК являются преобладающими в составе серого вещества головного мозга. Обеспеченность ими - необходимое условие для интеллектуального развития плода и ребенка, профилактики болезни Альцгеймера. Кроме того, они обеспечивают передачу нервных импульсов между нейронами: стимулируют синаптогенез, регулируют взаимодействие в цепи «нейроны - глия», улучшают функционирование рецепторов, расположенных на мембранах нейронов, играют важную роль в нейрогенезе, защите от окислительного стреса, усиливают нейрогенез в гиппокампе (области мозга, отвечающей в познании, регуляции настроения) взрослых. В периоде внутриутробного развития стимулируют нейрогенез, синаптогенез и миграцию нейронов, оказывают влияние на развитие головного мозга и зрительного анализатора.

Арахидоновая кислота встречается (в основном в связанном состоянии) во всех клеточных мембранах, в большом количестве присутствует в нервной ткани. Является предшественником эйкозаноидов - простагландинов, лейкотриенов и тромбоксанов, которые участвуют в иммунорегуляции, воспалительных и других биологических процессах.

ЭПК является предшественником простаноидов - биологически активных соединений, играющих роль в регуляции кровотока и процессов тромбообразования, а также иммунных реакций.

ДГК в наибольшем количестве содержится в мембранах клеток нервной ткани и сетчатки глаза, обладает мощным противовоспалительным действием. 


\section{Содержание в продуктах, суточная потребность}

Основным источником омега-3 ПНЖК являются морепродукты, так как лишь 2-10 \% $\alpha$-линоленовой кислоты может превращаться в ЭПК и ДГК (табл. 19).

Необходимо обратить внимание, что омега-3 ПЖНК в достаточном количестве в организм человека поставляет именно морская рыба, тогда как рыба, выращенная в рыбных хозяйствах, не обладает подобными свойствами ввиду того, что выращивается, как правило, на кормах, содержащих малое количество омега-3.

Таблица 19

Содержание ПНЖК в продуктах питания

\begin{tabular}{|c|c|c|}
\hline Класс ЖК & Представители & Пищевые источники \\
\hline \multirow[t]{2}{*}{$\begin{array}{c}\text { Омега-6 } \\
\text { ПНЖК }\end{array}$} & $\begin{array}{c}\text { Линолевая } \\
\text { кислота }\end{array}$ & $\begin{array}{l}\text { Растительные масла (подсолнечное, кукурузное, } \\
\text { хлопковое, льняное, соевое, сафлоровое, кунжут- } \\
\text { ное, арахисовое, касторовое и др.), орехи - кедро- } \\
\text { вые, грецкие, сырые фисташки, семена подсол- } \\
\text { нечника, тыквы, кунжута, льна, соевые бобы }\end{array}$ \\
\hline & $\begin{array}{c}\text { Арахидоновая } \\
\text { кислота }\end{array}$ & $\begin{array}{l}\text { Тресковый, лососёвый, свиной, говяжий, бараний } \\
\text { жиры, сливочное масло, красное мясо, яйца }\end{array}$ \\
\hline \multirow[t]{3}{*}{$\begin{array}{l}\text { Омега-3 } \\
\text { ПНЖК }\end{array}$} & $\begin{array}{c}\alpha \text {-линоленовая } \\
\text { кислота }\end{array}$ & $\begin{array}{l}\text { Растительные масла (подсолнечное, кукурузное, } \\
\text { льняное, хлопковое, рапсовое, соевое масла, гор- } \\
\text { чичное), хлеб из муки грубого помола (с кусоч- } \\
\text { ками зерен), семена льна, чиа, грецкие орехи, } \\
\text { темно-зеленые овощи (брюссельская капуста, } \\
\text { шпинат, брокколи) }\end{array}$ \\
\hline & $\begin{array}{c}\text { Эйкозапентаеновая } \\
\text { кислота }\end{array}$ & \multirow{2}{*}{$\begin{array}{l}\text { Моллюски, морская рыба, икра, мясо морских } \\
\text { животных, питающихся зоопланктоном и рыбой; } \\
\text { ламинария (морская капуста), некоторые назем- } \\
\text { ные растениях (мох, лишайник (ягель) и папорот- } \\
\text { ник) и мясо диких животных, поедающих эти } \\
\text { растения }\end{array}$} \\
\hline & $\begin{array}{c}\text { Докозагексаеновая } \\
\text { кислота }\end{array}$ & \\
\hline
\end{tabular}

Кроме того, следует помнить, что омега-3 ПНЖК очень чувствительны к воздействию окислителей, таких как кислород воздуха. В связи с этим пищевые добавки - это способ легко 
и быстро достичь необходимых доз. Биологически активную добавку рыбий жир получают из мяса жирной рыбы (например тунца) или из печени нежирной рыбы (например печени трески). В типичной добавке с рыбьим жиром ЭПК и ДГК вместе составляют около $30 \%$ присутствующих жирных кислот, так что 1 г капсульного рыбьего жира будет обеспечивает около 0,3 г ЭПК+ДГК.

\section{Эпидемиология}

Суточная потребность в насыщенных и мононенасыщенных жирных кислотах не более $10 \%$ калорийности суточного рациона, ПНЖК для взрослых - 6-10\% суточного рациона, для детей - 5-10\%. Суточная потребность в ПНЖК достаточно высока: от 3-9 г, покрыть которую только за счет питания практически невозможно, поэтому крайне актуальным является дополнительное потребление омега-3 ЖК (ЭПК и ДГК) в индивидуально подобранных дозах.

В настоящее время даже в относительно обеспеченных странах значительная часть населения потребляет пищу с низким содержанием ДГК и ЭПК (Европа, Австралия, США около 0,1-0,5 г/сут; для сравнения, Япония - 2 г/сут) и высоким содержанием омега-6 ПНЖК.

В рационе жителей России в последние десятилетия сократилось потребление жирной морской рыбы, что способствует формированию дефицита потребления омега-3 ПНЖК населением России. Дефицит омега-3 обнаруживается у 75,4 \% россиян в возрасте от года до 90 лет, наиболее тяжелый дефицит (омега-3-индекс 4-30\%) - у детей и подростков в возрасте до 18 лет.

Около 30 \% женщин в России курят. До 25 \% продолжают курить во время беременности. Курение оказывает ингибирующее воздействие на метаболизм и биодоступность омега-3 ПНЖК и приводит к снижению содержания их в сыворотке крови омега-3 ПНЖК. 
В процессе метаболизма омега-3 и омега-6 ПНЖК конкурируют за ферменты, поэтому непропорционально высокое поступление омега-6 ПНЖК с растительными маслами ограничивает и замедляет образование ЭПК и ДПК. В связи с этим адекватное соотношение омега- 6 и омега-3 имеет значение большее, чем их количественное содержание в рационе.

Согласно международным рекомендациям, оптимальное соотношение в суточном рационе омега-6 к омега-3 должно составлять 1:5-1:15.

Минимальная суточная потребность человека в линолевой кислоте составляет 2-6 г, что эквивалентно 10-15 г (2-3 чайные ложки) подсолнечного масла.

Минимальная суточная потребность человека в $\alpha$-линоленовой кислоте составляет 0,8-1,6 г/сут, или 1-2\% от калорийности суточного рациона.

Суточная потребность человека в ЭПК и ДГК (в том числе в составе пищевых добавок) - 2 г в сутки.

Международное общество по изучению жирных кислот и липидов (ISSFAL) рекомендует взрослым людям потреблять по крайней мере 500 мг/сут ЭПК + ДГК, а беременным и кормящим женщинам - дополнительно (сверх общих доз для взрослого населения) 200 мг/сут ДГК. Министерство здравоохранения США (2010) рекомендует беременным и кормящим женщинам употреблять в неделю 8-12 унций (226-340) морепродуктов, что эквивалентно 300-900 мг ЭПК+ДГК. Американская ассоциация сердца (АНА) рекомендует взрослым употреблять в пищу морскую рыбу не реже двух раз в неделю.

\section{Симптомы дефицита и избытка}

Симптомы дефицита омега-6 ПНЖК: жировая дегенерация печени, репродуктивные нарушения, у детей - задержка роста. 
Симптомы дефицита омега-3 ПНЖК: нарушение когнитивных функций, снижение остроты зрения, неврологические нарушения.

Недостаток линолевой кислоты приводит к увеличению проницаемости рогового слоя эпидермиса вследствие замещения линолевой кислоты олеиновой, что приводит к повышению проницаемости рогового слоя для токсинов, аллергенов, бактерий и дифференцировке кератиноцитов, что влечет за собой к развитие атопического дерматита.

Омега-3 ПНЖК способствуют профилактике и облегчают течение заболеваний сердечно-сосудистой системы (инфаркт миокарда, ИБС, гипертоническая болезнь), различных видов онкопатологии (молочных желез, толстой кишки, простаты и т.д.), бронхиальной астмы, воспалительных заболеваний кишечника, ревматоидного артрита и остеопороза, в том числе у женщин, получающих менопаузальную гормональную терапию, депрессии, биполярного расстройства.

\section{Участие в репродукции}

Омега-3 ПНЖК принимают участие в процессах имплантации плодного яйца и оказывают большое влияние на течение беременности и развитие плода:

1. Профилактика акушерских осложнений:

- привычное невынашивание;

- преждевременные роды (снижение риска на 40-50 \%);

- преэклампсия и артериальная гипертензия у беременных;

- тромбофилические осложнения;

- фетоплацентарная недостаточность.

2. Улучшение маточно-плацентарного и плодово-плацентарного кровотока.

3. Лечение и профилактика послеродовой депрессии. В течение последнего триместра беременности плод потребляет около 67 мг/сут ДГК через плаценту, а затем через грудное молоко. 
Это способствует истощению запасов ДГК в организме матери и повышает риск послеродовой депрессии.

4. Профилактика задержки внутриутробного развития плода, низкой массы тела новорожденного.

5. Снижение риска развития синдрома дефицита внимания с гиперактивностью у детей, биполярного расстройства.

Количество омега-3 ПНЖК, поступающих к плоду, коррелирует с количеством, потребляемым матерью. Дети, чьи матери получали достаточное количество омега-3 ПНЖК во время беременности, имеют более высокий уровень умственного развития, познавательных способностей, внимания, лучшую моторнозрительную координацию и остроту зрения. Недостаток же приводит к формированию асоциального поведения.

Усиленный захват и перенос ДГК и арахидоновой кислоты от матери к плоду наблюдается в третьем триместре беременности. Организм недоношенного ребенка, недополучивший длинноцепочечные ПНЖК в период гестации, способен метаболизировать незаменимые жирные кислоты, однако их количества может быть недостаточно. Повышенная потребность детей первого года жизни в ПНЖК обусловлена быстрым ростом мозга, вес которого увеличивается в этот период в три раза (табл. 20).

Т аблица 20

Содержание ПНЖК в грудном молоке, \%

\begin{tabular}{|c|c|c|c|c|}
\hline $\begin{array}{c}\text { Класс } \\
\text { ЖК }\end{array}$ & Представители & Молозиво & $\begin{array}{c}\text { Переходное } \\
\text { молоко }\end{array}$ & $\begin{array}{c}\text { Зрелое } \\
\text { молоко }\end{array}$ \\
\hline \multirow{2}{*}{$\begin{array}{c}\text { Омега-6 } \\
\text { ПНЖК }\end{array}$} & Линолевая кислота & $7,1-8,3$ & $8,6-9,0$ & $6-9$ \\
\cline { 2 - 5 } & Арахидоновая кислота & $0,3-0,4$ & $0,3-0,8$ & $0,1-0,2$ \\
\hline \multirow{2}{*}{ Омега-3 } & $\alpha$-линоленовая кислота & $0,2-0,3$ & $0,3-0,4$ & 0,3 \\
\cline { 2 - 5 } & Эйкозапентаеновая кислота & $0,4-0,8$ & $0,2-0,8$ & $0,1-0,6$ \\
\cline { 2 - 5 } & Докозагексаеновая кислота & $0,1-1,4$ & 0,3 & Отсутствует \\
\hline
\end{tabular}




\section{Способы лабораторной диагностики микроэлементного статуса}

Определение количественного содержания жирных кислот в венозной крови проводится методом газовой хроматографии с масс-селективным детектированием. Кроме количественного анализа возможно определение омега-3-индекса расчетного показателя (выраженное в процентах отношение суммы ЭПК+ДГК к общему содержанию жирных кислот в мембране эритроцитов).

В последнее время наибольшее значение уделяют не отдельной концентрации омега-3 и омега-6, а их соотношению. Считается, что наиболее эффективным соотношением омега-3/ омега-6 для профилактики заболеваний сердца, сосудов, костной ткани и онкологий является соотношение 1:1-5:1.

Анализ рекомендуется проводить не чаще раза в три месяца, потому что за это время омега-3 накапливается клеточными мембранами.

\section{Варианты коррекции}

Широкий спектр клинико-фармакологических эффектов и высокая безопасность современных биологически активных добавок (ЭПК и ДГК) позволяют эффективно применять их у здоровых лиц, в том числе и у детей. Кроме того, необходимо помнить, что рыба как высокоаллергенный продукт часто исключается из рациона детей, следовательно, для коррекции поступления ПНЖК необходимо использовать БАД.

Современные БАД ПНЖК производят в основном из жиров рыб или морских млекопитающих, сырьем являются фермерский лосось, дикие анчоусы. Также существуют добавки, полученные из водорослей, однако нет достаточной доказательной базы по их эффективности. 
Всем женщинам в периконцепционный период желательно рекомендовать дополнительное поступление ПНЖК в дозировке 200-300 мг/сут с последующим продолжением на протяжении всей гестации.

Рекомендуется дополнительная дотация омега-3 ПНЖК беременным с АФС и другими нарушениями гемостаза, начиная со второго триместра беременности, включать в комплексную терапию омега-3 ПНЖК в течение месяца и проводить повторные курсы приема омега-3 ПНЖК через два месяца. 


\section{1. ВИТАМИН D}

Витамин D представляет собой хорошо известный стероидный гормон, который имеет специфический цитозольный рецептор и участвует в регуляции почти $3 \%$ генома человека. Первоначально вит. D был описан как вещество, способное лечить рахит, и был назван «D», поскольку он был четвертым в последовательности обнаруженных витаминов. Исключительные успехи в исследованиях витамина произошли с тех пор, как Адольф Виндаус в 1928 г. был удостоен Нобелевской премии за его открытие. В течение следующих нескольких десятилетий вит. D изучался в основном в диетических условиях, а затем в исследованиях метаболизма, что привело к открытию 25-гидроксивитамина D [25(OH)D] лабораторией Делука в 1968 г. Классическая точка зрения на функции этого витамина свидетельствует о его центральной роли в метаболизме кальция и фосфата, однако в течение последнего десятилетия дефицит вит. D стал ассоциироваться с многочисленными явлениями и состояниями среди населения в целом, такими как падения, переломы, диабет, аутоиммунные заболевания, сердечно-сосудистые и почечные заболевания, туберкулез, депрессия, нейродегенеративные заболевания и рак.

\section{Основы метаболизма}

В организме человека значимая часть вит. D образуется в результате кожного синтеза, индуцированного солнечным светом (примерно 80 \%), остальное поступает с пищей и добавками. Витамин D синтезируется в организме посредством сложной серии этапов, которые начинаются в фибробластах дермы и эпидермальных кератиноцитах под воздействием ультрафиолетовых лучей солнечного света (длина волны между 290 и 315 нм), 
когда молекула предшественника холестерина (7-дегидрохолестерин) превращается в предшественник вит. D - холекальциферол (вит. $\mathrm{D}_{3}$ ). Впоследствии вит. $\mathrm{D}_{3}$ гидроксилируется в печени (с образованием $\left.25(\mathrm{OH}) \mathrm{D}_{3}\right)$, а затем в почках с выделением наиболее активной гормональной формы этих соединений 1,25-дигидроксихолекальциферола, или кальцитриола. Необходимость активации молекулы вит. D до гормональной формы 1,25-дигидроксивитамина D для достижения полной биологической активности послужила основанием для использования термина «гормон D».

В кровотоке метаболиты вит. D в основном связаны с витамин-D-связывающим белком и в меньшей степени с альбумином и липопротеинами, и только небольшая часть (менее 1 \%) циркулирует в несвязанной (свободной) форме. Хотя некоторые ткани могут поглощать связанные с белком метаболиты вит. D, большинство клеток зависят от свободных его метаболитов, которые диффундируют через клеточную мембрану, чтобы получить доступ к расположенным внутри клетки витамин-D-peцепторам. Считается, что действие вит. D на клетки-мишени подобно таковому у стероидных гормонов. Свободный гормон проникает через плазматическую мембрану и взаимодействует со специфическим ядерным рецептором, известным как рецептор вит. D и представляющим собой ДНК-связывающий белок. В дальнейшем этот белок усиливает транскрипцию мРНК, которые кодируют белки, транспортирующие кальций, белки костного матрикса или белки, регулирующие клеточный цикл.

«Инактивация» кальцитриола и других соединений вит. D достигается главным образом 24-гидроксилированием с образованием 1,24,25(OH)холекальциферола; этот этап также происходит преимущественно в почках и осуществляется при участии ферментов системы цитохрома Р450.

На выработку вит. D влияют климат, местоположение страны проживания, старение, образ жизни и пигментация кожи. 


\section{Физиологические функции}

Биологические эффекты вит. D определяются особенностями его рецепторов, которые экспрессируются в различных органах и тканях, включая скелет, иммунную систему, паращитовидные железы и ткани репродуктивной системы. Среди основных витамин-D-обусловленных эффектов выделяют следующие:

- поддержание гомеостаза кальция (увеличение его активного транспорта) и фосфора, которые необходимы для нормальной минерализации костей, сокращения мышц, нервной проводимости во всех клетках тела человека;

- модуляция транскрипции белков клеточного цикла, которые уменьшают пролиферацию клеток и увеличивают дифференциацию ряда специализированных клеток организма (например предшественников остеокластов, энтероцитов, кератиноцитов и т.д.);

- иммуномодулирующие свойства (ингибирование пролиферации Т-клеток, ингибирование IFN- $\gamma$, IL-17 и индукцию IL-4);

- ключевую регуляцию системного воспаления, окислительного стресса и дыхательной функции митохондрий;

- нормогликемический эффект - регуляция выработки инсулина в поджелудочной железе, играет определенную роль в профилактике и лечении СД 1-го типа, нарушении толерантности к глюкозе и инсулинорезистентности, СД 2-го типа;

- положительное влияние на мышечную силу;

- влияние на репродуктивную систему: участие в процессах фолликуло- и сперматогенеза, имплантации.

\section{Содержание в продуктах, суточные нормативы потребления}

Более подробно пищевые источники вит. D, ранжированные по количеству пищевых волокон и энергии на стандартные порции пищи и на 100 граммов пищи, представлены в табл. 21. 
Таблица 21

Основные пищевые источники витамина D

\begin{tabular}{|c|c|c|c|c|}
\hline Продукт & \begin{tabular}{|c|} 
Стандарт- \\
ный \\
размер \\
порции \\
\end{tabular} & $\begin{array}{c}\text { Калорий- } \\
\text { ность } \\
\text { в стандарт- } \\
\text { ной порции } \\
\end{array}$ & $\begin{array}{c}\text { Пищевые } \\
\text { волокна } \\
\text { в стандартной } \\
\text { порции, г }\end{array}$ & $\begin{array}{c}\text { Калорий } \\
\text { на } 100 \\
\text { грамм }\end{array}$ \\
\hline 1 & 2 & 3 & 4 & 5 \\
\hline Лосось, нерка, консервы & $90 \Gamma$ & 142 & 17,9 & 167 \\
\hline $\begin{array}{l}\text { Форель радужная, выращенная, } \\
\text { приготовленная }\end{array}$ & 90 г & 143 & 16,2 & 168 \\
\hline Лосось, копченый & 90 г & 99 & 14,5 & 117 \\
\hline Рыба-меч, приготовленная & $90 \Gamma$ & 146 & 14,1 & 172 \\
\hline Осетр копченый & $90 \Gamma$ & 147 & 13,7 & 173 \\
\hline Лосось консервированный & $90 \Gamma$ & 117 & 12,3 & 138 \\
\hline Рыбий жир, печень трески & $\begin{array}{l}1 \text { чайная } \\
\text { ложка }\end{array}$ & 41 & 11,3 & 902 \\
\hline Лосось, нерка, приготовленный & $90 \Gamma$ & 144 & 11,1 & 169 \\
\hline Лосось, розовый, приготовленный & $90 \Gamma$ & 130 & 11,1 & 153 \\
\hline Сиг, смешанные виды, копченый & $90 \Gamma$ & 92 & 10,9 & 108 \\
\hline $\begin{array}{l}\text { Скумбрия тихоокеанская приго- } \\
\text { товленная }\end{array}$ & 90 г & 171 & 9,7 & 201 \\
\hline Лосось, кижуч, приготовленный & $90 \Gamma$ & 118 & 9,6 & 139 \\
\hline $\begin{array}{l}\text { Тунец, светлый, консервирован- } \\
\text { ный в масле, сушеный } \\
\end{array}$ & 90 г & 168 & 5,7 & 198 \\
\hline $\begin{array}{l}\text { Палтус атлантический и тихо- } \\
\text { океанский, приготовленный }\end{array}$ & 90 г & 94 & 4,9 & 111 \\
\hline $\begin{array}{l}\text { Селедка атлантическая, приго- } \\
\text { товленная }\end{array}$ & 90 г & 173 & 4,6 & 203 \\
\hline $\begin{array}{l}\text { Сардина, консервированная } \\
\text { в масле }\end{array}$ & 90 г & 177 & 4,1 & 208 \\
\hline Морской окунь, приготовленный & $90 \Gamma$ & 93 & 3,9 & 109 \\
\hline Тилапия приготовленная & 90 г & 109 & 3,1 & 128 \\
\hline $\begin{array}{l}\text { Камбала (камбала и камбала) } \\
\text { приготовленная }\end{array}$ & 90 г & 73 & 3.0 & 86 \\
\hline $\begin{array}{l}\text { Обезжиренное шоколадное } \\
\text { молоко (2\%-ное) }\end{array}$ & 1 чашка & 190 & 3.0 & 76 \\
\hline Цельное молоко & 1 чашка & 149 & 3,2 & 61 \\
\hline $\begin{array}{l}\text { Молоко (обезжиренное, } \\
1 \% \text {-ное и } 2 \% \text {-ное) } \\
\end{array}$ & 1 чашка & $83-122$ & 2,9 & $34-50$ \\
\hline Соевое молоко & 1 чашка & 109 & 2,9 & 45 \\
\hline $\begin{array}{l}\text { Обогащенные, готовые к упот- } \\
\text { реблению крупы (разные) }\end{array}$ & $\begin{array}{c}1 / 3-11 / 4 \\
\text { чашка }\end{array}$ & $74-247$ & $0,2-2,5$ & $248-443$ \\
\hline
\end{tabular}


Окончание табл. 21

\begin{tabular}{|l|c|c|c|c|}
\hline \multicolumn{1}{|c|}{1} & 2 & 3 & 4 & 5 \\
\hline Апельсиновый сок обогащенный & 1 чашка & 117 & 2.5 & 47 \\
\hline Миндальное молоко & 1 чашка & $91-120$ & 2,4 & $38-50$ \\
\hline Рисовое молоко & 1 чашка & 113 & 2,4 & 47 \\
\hline Свинина вареная & 90 г & $122-390$ & $0,2-2,2$ & $143-459$ \\
\hline Грибы сморчки сырые & $1 / 2$ стакана & 10 & 1,7 & 31 \\
\hline Маргарин (разный) & $\begin{array}{c}1 \text { столовая } \\
\text { ложка }\end{array}$ & $75-100$ & 1,5 & $533-717$ \\
\hline Грибы, лисички, сырые & $1 / 2$ стакана & 10 & 1.4 & 38 \\
\hline Яйцо, сваренное вкрутую & 1 штука & 78 & 1,1 & 155 \\
\hline
\end{tabular}

Сравнительная характеристика диетических норм потребления 25-гидроксивитамина D в зависимости от возраста и пола, а также его допустимые верхние уровни, рекомендуемые мировыми профессиональными сообществами в сфере питания, представлены в табл. 22, 23.

Таблица 22

Сравнительная характеристика диетических норм потребления 25-гидроксивитамина D

\begin{tabular}{|c|c|c|c|c|c|c|}
\hline \multirow{3}{*}{ Параметр } & \multicolumn{6}{|c|}{ Страна (орган здравоохранения) } \\
\hline & \multicolumn{2}{|c|}{$\begin{array}{c}\text { США, } \\
\text { Канада, } \\
\text { Институт } \\
\text { медицины }\end{array}$} & $\begin{array}{c}\text { Европа, } \\
\text { Европейское } \\
\text { агентство по } \\
\text { безопасности } \\
\text { пищевых } \\
\text { продуктов }\end{array}$ & $\begin{array}{l}\text { Германия, } \\
\text { Австрия и } \\
\text { Швейцария }\end{array}$ & $\begin{array}{c}\text { Великобритания, } \\
\text { Научно-консуль- } \\
\text { тативный коми- } \\
\text { тет по питанию }\end{array}$ & $\begin{array}{c}\text { Страны } \\
\text { Север- } \\
\text { ной } \\
\text { Европы }\end{array}$ \\
\hline & \multicolumn{6}{|c|}{$\begin{array}{c}\text { Потребление витамина D в мкг (международные единицы, ME) } \\
\text { в день (1 мкг }=40 \mathrm{ME})\end{array}$} \\
\hline 1 & 2 & 3 & 4 & 5 & 6 & 7 \\
\hline $\begin{array}{l}\text { Целевой } \\
\text { показатель } \\
\text { 25(ОН)Д } \\
\text { в нмоль/л } \\
\end{array}$ & 40 & 50 & 50 & 50 & 50 & 25 \\
\hline 0-6 месяцев & $\begin{array}{c}10 \\
(400)\end{array}$ & & - & $10(400)$ & $\begin{array}{c}8,5-10 \\
(300-400)\end{array}$ & - \\
\hline 7-12 месяцев & $\begin{array}{c}10 \\
(400)\end{array}$ & & $10(400)$ & $10(400)$ & $\begin{array}{c}8,5-10 \\
(300-400)\end{array}$ & $\begin{array}{c}10 \\
(400)\end{array}$ \\
\hline
\end{tabular}


Окончание табл. 22

\begin{tabular}{|l|c|c|c|c|c|c|}
\hline \multicolumn{1}{|c|}{1} & 2 & 3 & 4 & 5 & 6 & 7 \\
\hline $1-3$ года & $\begin{array}{c}10 \\
(400)\end{array}$ & $\begin{array}{c}15 \\
(600)\end{array}$ & $15(600)$ & $20(800)$ & $10(400)$ & $\begin{array}{c}10 \\
(400)\end{array}$ \\
\hline $4-6$ лет & $\begin{array}{c}10 \\
(400)\end{array}$ & $\begin{array}{c}15 \\
(600)\end{array}$ & $15(600)$ & $20(800)$ & $10(400)$ & $\begin{array}{c}10 \\
400)\end{array}$ \\
\hline $7-8$ лет & $\begin{array}{c}10 \\
(400)\end{array}$ & $\begin{array}{c}15 \\
(600)\end{array}$ & $15(600)$ & $20(800)$ & $10(400)$ & $\begin{array}{c}10 \\
(400)\end{array}$ \\
\hline $9-10$ лет & $\begin{array}{c}10 \\
(400)\end{array}$ & $\begin{array}{c}15 \\
(600)\end{array}$ & $15(600)$ & $20(800)$ & $10(400)$ & $\begin{array}{c}10 \\
(400)\end{array}$ \\
\hline $11-14$ лет & $\begin{array}{c}10 \\
(400)\end{array}$ & $\begin{array}{c}15 \\
(600)\end{array}$ & $15(600)$ & $20(800)$ & $10(400)$ & $\begin{array}{c}10 \\
(400)\end{array}$ \\
\hline $15-17$ лет & $\begin{array}{c}10 \\
(400)\end{array}$ & $\begin{array}{c}15 \\
(600)\end{array}$ & $15(600)$ & $20(800)$ & $10(400)$ & $\begin{array}{c}10 \\
(400)\end{array}$ \\
\hline $18-69$ лет & $\begin{array}{c}10 \\
(400)\end{array}$ & $\begin{array}{c}15 \\
(600)\end{array}$ & $15(600)$ & $20(800)$ & $10(400)$ & $\begin{array}{c}10 \\
(400)\end{array}$ \\
\hline $70-74$ года & $\begin{array}{c}10 \\
(400)\end{array}$ & $\begin{array}{c}20 \\
(600)\end{array}$ & $15(600)$ & $20(800)$ & $10(400)$ & $\begin{array}{c}10 \\
400)\end{array}$ \\
\hline $\begin{array}{l}75 \text { лет и } \\
\text { старше }\end{array}$ & $\begin{array}{c}10 \\
(400)\end{array}$ & $\begin{array}{c}20 \\
(600)\end{array}$ & $15(600)$ & $20(800)$ & $10(400)$ & $\begin{array}{c}20 \\
(800)\end{array}$ \\
\hline $\begin{array}{l}\text { Беремен- } \\
\text { ность }\end{array}$ & $\begin{array}{c}10 \\
(400)\end{array}$ & $\begin{array}{c}15 \\
(600)\end{array}$ & $15(600)$ & $20(800)$ & $10(400)$ & $\begin{array}{c}10 \\
(400)\end{array}$ \\
\hline $\begin{array}{l}\text { Кормление } \\
\text { грудью }\end{array}$ & $\begin{array}{c}10 \\
(400)\end{array}$ & $\begin{array}{c}15 \\
(600)\end{array}$ & $15(600)$ & $20(800)$ & $10(400)$ & $\begin{array}{c}10 \\
(400)\end{array}$ \\
\hline
\end{tabular}

Таблица 23

Допустимые верхние уровни потребления 25 -гидроксивитамина D

\begin{tabular}{|l|c|c|}
\hline \multirow{3}{*}{$\begin{array}{c}\text { Возрастная группа, } \\
\text { категория }\end{array}$} & \multicolumn{2}{|c|}{ Страна (орган здравоохранения) } \\
\cline { 2 - 3 } & $\begin{array}{c}\text { США, Канада } \\
\text { (Институт Медицины) }\end{array}$ & $\begin{array}{c}\text { Европа, Европейское агентство по } \\
\text { безопасности пищевых продуктов }\end{array}$ \\
\cline { 2 - 3 } & \multicolumn{2}{|c|}{$\begin{array}{c}\text { Витамин D в мкг (международные единицы, МЕ) } \\
\text { в день (1 мкг = 40 МЕ) }\end{array}$} \\
\hline $0-6$ месяцев & $25(1000)$ & $25(1000)$ \\
\hline $7-12$ месяцев & $37,5(1500)$ & $35(1400)$ \\
\hline $1-3$ года & $62,5(2500)$ & $50(2000)$ \\
\hline $4-8$ лет & $75(3000)$ & $50(2000)$ \\
\hline $9-10$ лет & $100(4000)$ & $50(2000)$ \\
\hline $11-17$ лет & $100(4000)$ & $100(4000)$ \\
\hline 18 лет и старше & $100(4000)$ & $100(4000)$ \\
\hline Беременность & $100(4000)$ & $100(4000)$ \\
\hline Кормление грудью & $100(4000)$ & \\
\hline
\end{tabular}




\section{Эпидемиология потребления}

Существующая проблема оценки общего объема потребления вит. D, который может поступать в рацион или вырабатываться в коже под воздействием солнечного света, затрудняет оценку адекватного общего потребления данного вещества для населения в целом. Точные данные о составе пищевых продуктов для вит. D отсутствуют, что усугубляет сложность оценки потребления с пищей. Синтез кожи также трудно оценить, поскольку на него влияют такие непредсказуемые факторы, как возраст, время года, широта, время суток, воздействие кожи, использование солнцезащитного крема и т.д. У людей с избытком вит. D оценка синтеза в коже составляет около 10 мкг в день, при этом общее потребление оценивается в 15 мкг.

Данные, собранные Национальным обследованием здоровья и питания в Северной Америке, документально подтверждают 4-кратное увеличение распространенности дефицита вит. D за последние 10-15 лет, при этом затронуто $36 \%$ населения США. В этом исследовании были продемонстрированы тревожные данные о том, что группы населения с наибольшей физиологической потребностью в вит. D, такие как беременные женщины, новорожденные, дети и подростки, также подвергаются наибольшему риску дефицита вит. D.

Недостаточное потребление вит. D с пищей, увеличивающееся загрязнение окружающей среды, изменение образа жизни с последующим уменьшением пребывания на солнце, сопутствующее повышенное использование солнцезащитного крема, вызванное опасениями по поводу канцерогенного потенциала солнечного света, - все это факторы, способствующие почти пандемии недостаточности вит. D. Классификация причин дефицита вит. D представлена в табл. 24.

Также хорошо изучена обратная зависимость между уровнями 25(OH)D в сыворотке и индексом массы тела (ИМТ). И хотя парадигма «причины и следствия» этой связи неясна, 
ожирение признано независимым фактором риска гиповитаминоза D, при этом секвестрация жирорастворимого витамина в жировой ткани предлагается как механизм, объясняющий более низкие уровни циркулирующего $25(\mathrm{OH}) \mathrm{D}$, наблюдаемые у людей с избыточным весом и ожирением. Недавние эксперименты in vitro показывают, что $1,25(\mathrm{OH})_{2} \mathrm{D}$ вызывает повышение концентрации ионов кальция внутри адипоцитов, что, в свою очередь, может стимулировать липогенез и ингибировать липолиз.

Таблица 24

Основные причины дефицита витамина D

\begin{tabular}{|l|l|}
\hline \multicolumn{1}{|c|}{ Причина } & \multicolumn{1}{|c|}{ Пример } \\
\hline Снижение кожного синтеза & $\begin{array}{l}\text { Солнцезащитный крем, насыщенность кожи } \\
\text { пигментом, сезон / время дня, старение }\end{array}$ \\
\hline Повышенная секвестрация & Ожирение (ИМТ > 30) \\
\hline Снижение абсорбции & $\begin{array}{l}\text { Муковисцидоз, глютеновая болезнь, болезнь } \\
\text { Крона, желудочный анастомоз, лекарства, } \\
\text { снижающие всасывание холестерина }\end{array}$ \\
\hline Повышенный катаболизм & $\begin{array}{l}\text { Противосудорожные средства, глюкокорти- } \\
\text { коиды }\end{array}$ \\
\hline Грудное вскармливание & Исключительно, без добавок витамина D \\
\hline $\begin{array}{l}\text { Снижение синтеза 25-гидрокси- } \\
\text { витамина D }\end{array}$ & Печеночная недостаточность \\
\hline $\begin{array}{l}\text { Повышенная потеря 25-гидрокси- } \\
\text { витмаина D с мочой }\end{array}$ & Нефротическая протеинурия \\
\hline $\begin{array}{l}\text { Снижение синтеза 1,25-дигид- } \\
\text { роксивитамина D }\end{array}$ & Хроническая почечная недостаточность \\
\hline Наследственные расстройства & Устойчивость к витамину D \\
\hline
\end{tabular}

Группь риска по возникновению недостаточности или дефицита вит. D:

- младенцы и дети до 5 лет;

- пигментированная кожа (небелая этническая принадлежность);

- беременные и кормящие женщины, особенно подростки и молодые женщины;

- недостаток солнечного света; 
- люди старше 65 лет;

- ношение одежды, скрывающей кожу, или строгое использование солнцезащитного крема;

- многоплодная беременность с короткими интервалами;

- пожилые люди, прикованные к дому или находящиеся в закрытом помещении в течение длительного времени;

- веганство / вегетарианство или высокое потребление фитатов;

- нарушение всасывания (например воспалительные заболевания кишечника, целиакия, недостаточность поджелудочной железы);

- использование противосудорожных средств, рифампицина, холестирамина, антиретровирусных препаратов, глюкокортикоидов;

- определенные условия, например заболевание печени или почек, кистозный фиброз;

- ожирение (ИМТ> 30).

\section{Симптомы дефицита и избытка}

Недостаточность и дефицит вит. D могут протекать бессимптомно или сопровождаться некоторыми неспецифическими клиническими симптомами и признаками.

Клинические проявления дефицита вит. D на ранних стадиях могут включать: усталость, слабость, миалгии и судороги в мышцах, снижение настроения, раздражительность, нарушения сна, частые простудные заболевания, снижение аппетита, появление чувства жжения во рту.

При прогрессировании дефицитарного состояния может наблюдаться развитие остеопороза, а у детей - рахит, деформации позвоночника, задержка в росте и развитии.

Витамин D, как жирорастворимый витамин, вызывает опасения по поводу токсичности из-за чрезмерного приема добавок. Токсичность вит. D встречается нечасто и почти исклю- 
чительно у людей, которые длительно принимают его высокие дозы без контроля уровня в крови. Поскольку вит. D накапливается в жировой ткани и медленно попадает в кровоток, последствия токсичности могут сохраняться в течение нескольких месяцев после прекращения приема добавок. Однако широкое распространение вит. D в пищевых продуктах и напитках с 1930-х по 1950-е гг. в Соединенных Штатах и Европе привело к зарегистрированным случаям токсичности. Ранние симптомы токсичности вит. D включают желудочно-кишечные расстройства, такие как анорексия, диарея, запор, тошнота и рвота. Боль в костях, сонливость, постоянные головные боли, нерегулярное сердцебиение, потеря аппетита, боль в мышцах и суставах - это дополнительные симптомы, которые могут появиться в течение нескольких дней или недель приема препаратов. Учащенное мочеиспускание, особенно ночью, сильная жажда, слабость, нервозность и кожный зуд, появление камней в почках также могут беспокоит таких пациенток.

С клинической точки зрения интоксикация вит. D характеризуется гиперкальциемией, которой предшествует гиперкальциурия. Однако гиперкальциемия, вызванная интоксикацией вит. D, обычно возникает только при концентрациях 25(OH)D в сыворотке выше 375 нмоль/л (150 нг/мл) и встречается очень редко. Существует мнение, что необходимо рассматривать концентрации 25(OH)D выше 125 нмоль/л, если они поддерживаются в течение длительного времени как потенциально опасные. При этом текущие метаанализы наблюдательных исследований не сообщают о значительном повышении риска нежелательных явлений при концентрациях 25(OH)D в сыворотке выше 125 нмоль/л, поэтому до сих пор неясно, какие концентрации 25(OH)D в сыворотке следует использовать в качестве порогового уровня токсичности вит. D при его пероральном приеме.

Существуют три основные гипотезы токсичности вит. D:

1. Повышенные концентрации $1,25(\mathrm{OH}) \mathrm{D}$ в плазме приводят к увеличению внутриклеточных концентраций 1,24(OH)D. Эта ги- 
потеза не получила широкой поддержки, поскольку многие исследования показали, что токсичность вит. D связана с нормальным или незначительно повышенным 1,25(OH)D.

2. Потребление вит. D повышает уровни $25(\mathrm{OH}) \mathrm{D}$ в плазме до концентраций, которые превышают связывающую способность транспортного белка, а свободный 25(OH)D оказывает прямое влияние на экспрессию генов, как только он попадает в клетки-мишени. Одно только высокое потребление вит. D с пищей увеличивает $25(\mathrm{OH}) \mathrm{D}$ в плазме. Низкое сродство $1,25(\mathrm{OH}) \mathrm{D}$ к транспортному белку и его высокое сродство к собственному специфическому рецептору доминируют в нормальной физиологии. При интоксикации вит. D перегрузка различными метаболитами вит. D значительно снижает связывающую способность транспортного белка, позволяя другим метаболитам проникать в ядро клетки.

3. Потребление вит. D увеличивает концентрацию многих метаболитов вит. D, включая сам вит. D и 25(OH)D, и эти концентрации превышают способность связывания со специфическим белком и высвобождение «свободного» 1,25(OH)D, который попадает в клетки.

\section{Участие в репродукции}

Bсе больше данных подтверждают значимую роль вит. D в различных процессах, связанных с состоянием репродуктивного здоровья. Рецептор вит. D экспрессируется в тканях яичников и шейки матки, эндометрии и миометрии. Биологические эффекты вит. D на фертильность и репродуктивные ткани в целом изучались, но в основном на животных моделях. Напротив, данные молекулярных исследований, касающиеся механизмов, лежащих в основе действия вит. D в эндометрии человека в норме и при патологии, все еще скудны.

Известно, что уровни 25(OH)D в сыворотке крови позволяют прогнозировать реакцию яичников у женщин, подвергаю- 
щихся индукции овуляции кломифена цитратом. Было обнаружено, что низкие уровни $25(\mathrm{OH}) \mathrm{D}$ и дефицит вит. D ( $<25$ нмоль / л или $<10$ нг/ мл) связаны с более низкими темпами развития фолликулов и наступлением беременности после стимуляции яичников 50 мг кломифена.

Предполагается, что дефицит вит. D вносит свой вклад в патофизиологию ряда гинекологических заболеваний, из которых СПКЯ является наиболее изученным. Небольшое количество наблюдательных исследований выявляет обратную связь между уровнем $25(\mathrm{OH}) \mathrm{D}$ в сыворотке крови с инсулинорезистентностью, клиническими проявлениями гиперандрогении и циркулирующими в сыворотке крови андрогенами (свободным тестостероном и андростендионом) у женщин с СПКЯ. Инсулинорезистентность, ожирение, системное воспаление и дислипидемия, то есть системообразующие метаболические явления, которые обычно встречаются при СПКЯ, подробно описаны в контексте недостаточности вит. D. Таким образом, можно сделать вывод, что гиповитаминоз D играет значимую роль в патофизиологии СПКЯ. Однако, поскольку большинство пациенток с СПКЯ имеют избыточный вес или страдают морбидным ожирением, трудно определить, вносит ли дефицит вит. D, независимо от избыточной массы тела, вклад в патогенез данного вида овариальной дисфункции.

Ограниченное количество исследований связывает дефицит вит. D с ПМС, миомой матки, дисменореей и, в последнее время, с ранним менархе. Результаты рандомизированного двойного слепого плацебо-контролируемого исследования продемонстрировали значительное уменьшение степени тяжести дисменореи и улучшение самочувствия пациенток, которое наблюдалось в течение двух месяцев после однократного приема $300000 \mathrm{ME}$ вит. D. Это исследование является одним из немногих случаев, когда причинно-следственная связь между низким уровнем вит. D и изучаемым результатом подтверждается таким серьезным дизайном работы. 
Есть данные об экспрессии рецепторов вит. D в нормальной и опухолевой ткани шейки матки, яичников и молочной железы.

Молекулярные механизмы сигнальных путей при раке шейки матки и яичников и их связь с вит. D до сих пор остаются не до конца изученными, однако значительный объем эпидемиологических данных свидетельствует о том, что дефицит вит. D может лежать в основе повышенного риска развития ненаследственных форм рака молочных желез.

Интересно отметить, что эндометриоз является одним из немногих заболеваний, которые были идентифицированы как результат относительного избытка вит. D. Недавнее исследование протеомного анализа сыворотки, взятой у пациентов с эндометриозом, продемонстрировало значительно более высокую экспрессию витамин-D-связывающего белка при данной патологии. Также при различных формах генитального эндометриоза определяется повышенный уровень витамин-D-связывающего белка в перитонеальной жидкости. Предполагается, что активность иммунных клеток и цитокинов, которые играют главенствующую роль в развитии и поддержании эндометриоидных гетеротопий, может модулироваться более высокими, чем обычно, уровнями вит. D и его метаболитов в брюшной полости.

Эффект активной формы вит. D как антипролиферативного, проапоптотического, противовоспалительного и индуцирующего дифференцировку агента был продемонстрирован на различных клеточных линиях рака эндометрия. Обработка кальцитриолом индуцировала остановку клеточного цикла в клетках рака эндометрия, подавляя некоторые регуляторы развития клеточного цикла, такие как циклин $\mathrm{D}_{1}$ и $\mathrm{D}_{3}$, и увеличивая экспрессию $\mathrm{p} 27$, хорошо известного ингибитора клеточного цикла.

Во время беременности гемодилюция матери сопровождается рядом физиологических изменений как в метаболизме вит. D, так и в составе тела матери; такая адаптация приводит к различиям в детерминантах ответа на добавление вит. D у беременных и небеременных женщин. Гестационный процесс со- 
провождается значительными изменениями в метаболизме кальция и фосфата, что способствует накоплению кальция в скелете плода, особенно в третьем триместре. В некоторых исследованиях описано увеличение концентрации $1,25(\mathrm{OH})_{2} \mathrm{D}$ в крови матери в течение последнего триместра беременности, в то время как в других исследованиях этого найдено не было. Более высокие уровни $1,25(\mathrm{OH})_{2} \mathrm{D}$ у матери необходимы для увеличения абсорбции кальция в кишечнике во время беременности и для поддержания кальция в метаболизме матери и плода, а также для регулирования некоторых функций иммунной системы во время беременности.

Основная циркулирующая форма, 25-гидроксивитамин D, легко проникает через плаценту и активируется в $1,25(\mathrm{OH})_{2} \mathrm{D}$ почками плода. Помимо почек, плацента потенциально может активировать 25(OH)D, поскольку она содержит фермент 1 - $\alpha$-гидроксилазу, продуцирующий $1,25(\mathrm{OH})_{2} \mathrm{D}$. Более того, плацента паракринно контролирует метаболизм вит. D и может также инактивировать 25(OH)D путем 24-гидроксилирования до $24,25(\mathrm{OH})_{2} \mathrm{D}$. Это делает возможным местное регулирование уровня вит. D в ткани плаценты, что может модулировать противовоспалительные эффекты и влиять на развитие беременности и / или перинатальные исходы. Кальцитриол проявляет мощные иммуномодулирующие свойства, ингибируя адаптивные ответы Т-хелперов-1, одновременно стимулируя врожденные антимикробные реакции в плацентарных клетках человека.

Однако следует учитывать, что большинство экспериментальных данных, определяющих роль $1,25(\mathrm{OH})_{2} \mathrm{D}$, активного метаболита вит. D, в репродукции, получены либо на моделях грызунов с дефицитом вит. D, вызванных диетой, либо на трансгенных мышах. Имеющиеся данные убедительно свидетельствуют о важности вит. D для успеха деторождения, одновременно подчеркивая необходимость дополнительных исследований, которые позволят лучше понять молекулярные механизмы эффектов вит. D в контексте репродукции. 


\section{Акушерские и перинатальные результаты витаминдефицитарных состояний}

Недостаточность вит. D у матери во время беременности распространенная и серьезная проблема общественного здравоохранения на глобальном уровне. Обменные процессы организма плода находятся в прямой зависимости от содержания в крови матери вит. D, кальция и фосфора, которые передаются через плаценту. В течение десятилетий считалось, что вит. D важен для беременной женщины и ее развивающегося плода только для поддержания гомеостаза кальция и целостности скелета. Исследования в течение этих десятилетий были направлены на ответ на вопрос о том, что необходимо для предотвращения гипокальциемии и потери костной массы или недоразвития у матери и ее новорожденного. Более поздние исследования выявили экстраскелетные и иммунологические эффекты вит. D, что поставило вопрос о важности вит. D во время беременности в новом свете.

Многочисленные обсервационные исследования сообщают о связи между статусом 25(OH)D во время беременности и различными акушерскими осложнениями, включая гестационную артериальную гипертензию и преэклампсию, гестационный сахарный диабет (ГСД).

Существующая литература, связывающая статус вит. D у матери с риском преэклампсии, неоднозначна. Современные наблюдательные исследования связывают дефицит вит. D с преэклампсией у людей. Хотя этиология данного акушерского синдрома не совсем ясна, патологическая плацентация, плохая плацентарная перфузия, эндотелиальная дисфункция и оксидативный стресс являются признанными механизмами, лежащими в основе преэклампсии. Присутствие вит. D и его рецепторов в плаценте, а также способность вит. D модулировать иммунные, воспалительные и сосудистые реакции предполагают причинную роль дефицита вит. D у матери в патогенезе преэклам- 
псии. Предполагается, что субоптимальные концентрации вит. D ведут к неполной инвазии трофобласта человека в децидуальную оболочку. Добавление вит. D предотвращает эндотелиальную дисфункцию, вызванную ишемией плаценты, за счет подавления плацентарной растворимой FMS-подобной тирозинкиназы-1, которая участвует в реализации патогенеза преэклампии. Норвежское исследование, проведенное в 2009 г. и включавшее более 23000 беременных, показало, что дополнительный прием вит. D влияет на вероятность развития преэклампсии. Снижение риска преэклампсии на 27 \% произошло у пациенток, принимавших 10-15 мкг вит. D в день, по сравнению с контрольной группой, не получавшей дополнительно данного витамина. Однако наряду с этим существует достаточное количество систематических обзоров и метаанализов, которые не показали, что вит. D оказывает значительное позитивное влияние на риск развития преэклампсии.

Роль вит. D в патогенезе гестационного сахарного диабета может быть обусловлена его участием в таких процессах нарушения толерантности к глюкозе, как чувствительность к инсулину, функция $\beta$-клеток и секреция инсулина. Иммунная дисфункция за счет воспалительной дисрегуляции (активация цитотоксических Т-лимфоцитов) связывает дефицит вит. D с нарушением толерантности матери и плода и повышенным риском ГСД. Статус матери 25(OH)D не имеет положительной связи с преждевременными родами.

Дефицит или недостаточность 25(OH)D ассоциированы с возникновением депрессивных состояний в анте- и постнатальном периодах. Несколько механизмов могут объяснить наблюдаемую связь между концентрацией $25(\mathrm{OH}) \mathrm{D}$ и риском депрессии во время беременности. Депрессия связана с нарушением регуляции функции оси «гипоталамус - гипофиз надпочечники», гиперактивностью симпатонадпочечниковой системы и повышенным уровнем воспалительных маркеров. 
Добавление 2000 ME вит. D в день во время беременности снижает риск антенатальной депрессии.

\section{Перинатальный дефицит}

Статус вит. D у матери может иметь долгосрочные последствия для здоровья потомства. Недавнее проспективное когортное исследование 424 беременных женщин продемонстрировало, что недостаточность вит. D у матери может влиять на развитие бедренной кости плода уже на 19-й неделе беременности. Имеются убедительные доказательства того, что добавка важна для снижения риска неонатальной гипокальциемии и повышения статуса 25(OH)D у новорожденных. Есть некоторые свидетельства, подтверждающие положительную взаимосвязь между статусом вит. D и массой тела при рождении и костной массой потомства, но противоречивые доказательства все еще существуют. Крупнейшее двойное слепое рандомизированное исследование безопасности и эффективности добавок вит. D (400, 2000 или $4000 \mathrm{ME})$ у беременных не выявило никаких различий в весе детей при рождении вне зависимости от доз, хотя значительное улучшение уровней циркулирующего $25(\mathrm{OH}) \mathrm{D}$ наблюдалось во всех группах. Дефицит вит. D также рассматривается как фактор риска аллергических заболеваний у детей, включая бронхиальную астму. У детей в возрасте 3-5 лет, матери которых имели низкие уровни $25(\mathrm{OH}) \mathrm{D}$ во время беременности, вероятность развития бронхоспазма и формирования астмы была на $40 \%$ больше в сравнении с данными контрольной группы. В совокупности существующие факты предполагают, что статус вит. D у матери может иметь долгосрочные последствия для здоровья их потомства, а негативные эффекты дефицита вит. D у матери могут распространяться далеко за пределы младенческого возраста. 


\section{Способы лабораторной диагностики}

Классификация статуса вит. D основана на содержании 25(OH)D в сыворотке крови, который в основном образуется в результате гидроксилирования вит. D в печени и является наилучшим индикатором для мониторинга. По сравнению с вит. D, 25(OH)D имеет гораздо более высокую концентрацию в сыворотке и более длительный период полувыведения (около трех недель по сравнению с одним днем) и поэтому считается лучшим параметром для определения поступления вит. D из различных источников. 1,25-дигидроксивитамин $\mathrm{D}\left(1,25[\mathrm{OH}]_{2} \mathrm{D}\right)$ - это так называемый активный гормон вит. D, или кальцитриол, который имеет наивысшее сродство к почти повсеместно выраженным рецепторам вит. D. Концентрации $1,25(\mathrm{OH})_{2} \mathrm{D}$ в сыворотке в основном происходят из почечного гидроксилирования $25(\mathrm{OH}) \mathrm{D}$ и в значительной степени зависят от регуляторов минерального обмена (например паратиреоидного гормона (ПТГ), фосфата или фактора роста фибробластов-23 (FGF-23)) или функции почек, чем при наличии субстрата 25(OH)D, поэтому они плохо отражают поступление вит. D.

Сегодня в арсенале клиницистов имеется несколько методов лабораторной оценки уровня 25(OH)D. Существуют два основных типа анализов, используемых для измерения 25OHD: иммунный анализ (обычно используемый в клинической практике) и анализ на основе хроматографии (обычно считающийся золотым стандартом для исследований). Очевидно, что использование разных методов в разных лабораториях приводит к большой вариативности результатов исследований. Таким образом, крайне важно, чтобы при определении уровней $25(\mathrm{OH}) \mathrm{D}$ в динамике использовался один и тот же метод и лаборатория, а также соблюдалось правило оценки концентрации 25(OH)D через три дня после последнего приема лечебных доз вит. D. Критерии оценки уровня вит. D, описанные в Федеральных клинических рекомендациях (2016), представлены в табл. 25. 
Критерии статуса витамина D

(Федеральные клинические рекомендации, 2016)

\begin{tabular}{|l|c|}
\hline \multicolumn{1}{|c|}{ Состояние } & Концентрация 25(ОН)D, нг/мл (нмоль/л) \\
\hline Дефицит витамина D & $20-30(50)$ \\
\hline Недостаточность витамина D & $30-100(75-250)$ \\
\hline Адекватные уровни витамина D & $30-60(75-150)$ \\
\hline $\begin{array}{l}\text { Рекомендуемые целевые значения при } \\
\text { коррекции дефицита витамина D }\end{array}$ & \\
\hline
\end{tabular}

Одновременно с определением уровня $25(\mathrm{OH}) \mathrm{D}$ в крови целесообразна также оценка основных параметров фосфорнокальциевого обмена исходно и после коррекции его уровня. Федеральные клинические рекомендации регламентируют оценку следующих параметров крови: кальций общий, кальций ионизированный, фосфор, паратгормон в крови, кальций и креатинин в суточной моче. Также рекомендуется определение креатинина для расчета скорости клубочковой фильтрации.

Существует консенсус в отношении того, что скрининг на дефицит вит. D в масштабах всей популяции путем измерения сывороточных концентраций 25(OH)D у бессимптомных пациентов с низким риском проводить не следует. С данной позицией согласно и российское медицинское сообщество, отметившее, что широкий популяционный скрининг дефицита вит. D не рекомендуется. Обоснованием для данной стратегии является ее достаточно высокая стоимость, с одной стороны, и отсутствие доказательной базы позитивных эффектов такого скрининга с другой.

\section{Варианты коррекции дефицита}

Концентрация циркулирующего 25(OH)D, достаточная для удовлетворения физиологических потребностей человека, является предметом постоянных дискуссий. 
В 2018 г. в Российской Федерации была принята национальная программа по коррекции недостаточности вит. D у детей и подростков, согласно которой были рекомендованы следующие профилактические дозы: 0-1 мес. - $500 \mathrm{ME}, 1$ мес. 1 год-1000 МЕ, 1-3 года - 1500 ME, 3-18 лет - 1000 ME.

Клинический протокол междисциплинарной ассоциации специалистов репродуктивной медицины (МАРС 2.0, 2020) по прегравидарной подготовке регламентирует прием профилактической дозы 800-2000 ME вит. D в сутки условно здоровым женщинам, которым не показано рутинное определение уровня $25(\mathrm{OH}) \mathrm{D}$ в сыворотке крови (при ИМТ менее $30 \mathrm{\kappa г} / \mathrm{M}^{2}$, отсутствии у анамнезе указаний на ПЭ, ГСД и невынашивание). Однако текущие рекомендации мировых профессиональных сообществ не демонстрируют консенсуса в отношении оптимального статуса вит. D во время беременности: Институт медицины (США) определяет уровень 25(OH)D в сыворотке 20 нг/мл (50 нмоль/л) как адекватный, а другие рекомендуют пороговое значение 75 нмоль/л.

При определении концентрации 25(OH)D 20-30 нг/мл показан приём $4000 \mathrm{ME} /$ сут холекальциферола в течение семи недель (или четырех недель по $7000 \mathrm{ME} /$ сут), а менее 20 нг/мл $4000 \mathrm{ME} /$ сут на протяжении 14 недель (или восьми недель по $7000 \mathrm{ME} /$ сут). После окончания курса лечения концентрацию вит. D оценивают повторно: если она ниже 30 нг/мл, то лечение повторяют, если выше - переходят на дозу 800-2000 МЕ сут.

Рекомендуемые суточные дозы и допустимый верхний предел вит. D при беременности и кормлении грудью в соответствии с практическими рекомендациями общества эндокринологов США представлены в табл. 26.

У пациентов с нормальной абсорбционной способностью на каждые $40 \mathrm{ME} /$ сут (1 мкг/сут) вит. $\mathrm{D}_{3}$ концентрация $25(\mathrm{OH}) \mathrm{D}$ в сыворотке увеличивается примерно на 0,3-0,4 нг/мл $(0,7-1,0$ нмоль/л). Наибольшие приросты наблюдаются у пациентов с самым низким начальным уровнем $25(\mathrm{OH}) \mathrm{D}$, но впоследст- 
вии снижаются, когда концентрация 25(OH)D достигает 40 нг/мл (100 нмоль/л). Также важно отметить, что можно с одинаковым успехом использовать режимы ежедневного, еженедельного или ежемесячного дозирования вит. D, поскольку они приводят к одинаковым концентрациям $25(\mathrm{OH}) \mathrm{D}$ в сыворотке крови.

Таблица 26

Рекомендуемые суточные дозы и допустимый верхний предел витамина D при беременности и лактации

\begin{tabular}{|c|c|c|c|}
\hline Состояние & Возраст, лет & $\begin{array}{c}\text { Суточная потребность, } \\
\text { МЕ/сут }\end{array}$ & $\begin{array}{c}\text { Верхний предел } \\
\text { витамина D, ME/сут }\end{array}$ \\
\hline \multirow{3}{*}{ Беременность } & $14-18$ & $600-1000$ & 4000 \\
\cline { 2 - 4 } & $19-30$ & $1500-2000$ & 10000 \\
\cline { 2 - 4 } & $31-50$ & $1500-2000$ & 10000 \\
\hline \multirow{2}{*}{$\begin{array}{c}\text { Кормление } \\
\text { грудью }\end{array}$} & $14-18$ & $600-1000$ & 4000 \\
\cline { 2 - 4 } & $19-30$ & $1500-2000$ & 10000 \\
\cline { 2 - 4 } & $31-50$ & $1500-2000$ & 10000 \\
\hline
\end{tabular}

Рекомендации ВОЗ по оказанию дородовой помощи для формирования положительного опыта беременности (2017) выражают следующее мнение мировых экспертов относительно приема витамина D: «...РЕКОМЕНДАЦИЯ А.9. Прием витамина D для улучшения материнских и перинатальных исходов беременным не рекомендуется.

\section{Комментарии}

- Эта рекомендация заменяет прежнюю рекомендацию из публикации ВО3 «Рекомендации: дополнительный прием витамина D беременными» (2012).

- Беременным следует объяснить, что наиболее важным фактором образования вит. D является солнечный свет. Время, которое необходимо находиться на солнце, неизвестно и зависит от многих переменных, таких как площадь открытой кожи, время дня, широта, время года, пигментация кожи (более темная кожа образует меньше вит. D, чем более светлая) и применение солнцезащитных средств. 
- Следует поощрять беременных получать надлежащее питание, что наилучшим образом достигается соблюдением правильной сбалансированной диеты, и обращаться к руководству по здоровому питанию.

- При выявленном дефиците вит. D во время беременности препараты вит. D могут назначаться в дозе, соответствующей норме суточной потребности (НСП), т.е. $200 \mathrm{ME} /$ сут (5 мкг/сут).

В соответствии с Федеральными клиническими рекомендациями 2019 г. «Нормальная беременность» пациенткам группы высокого риска по возникновению дефицита вит. D при низком его потреблении рекомендованы препараты кальция на протяжении всей беременности в дозе 10 мкг (400 ME)/сут (уровень доказательности В). В группе высокого риска гиповитаминоза вит. D его назначение снижает вероятность таких акушерских осложнений, как преэклампсия, гестационный сахарный диабет и задержка роста плода. К группе высокого риска гиповитаминоза D относятся пациентки с темной кожей, имеющие ограничения пребывания на солнце, со сниженным уровнем потребления мяса, жирной рыбы, яиц, с ИМТ до беременности $>30$ кг $/ \mathrm{M}^{2}$. Пациенткам группы низкого риска гиповитаминоза D не рекомендовано назначение вит. D (уровень доказательности В). 


\section{2. ВИТАМИН Е (ТОКОФЕРОЛ)}

Витамин Е, или токоферол, относится к жирорастворимым витаминам, его открытие приходится на 20-е гг. прошлого века. В 1920 г. ученые провели серию опытов на крысах. В ходе опытов самки крыс принимали в пищу молочные жиры и казеин. Такая диета пагубно отражалась на репродуктивной функции животных. Несмотря на нормальную овуляцию и зачатие, происходила внутриутробная гибель плода. У самцов дела обстояли не лучшим образом - у них нарушался сперматогенез. Прием таких богатых витаминами продуктов, как рыбий жир, мука, дрожжи, не приводил к улучшению плане деторождения. Однако фертильность (плодовитость) самок крыс восстанавливалась после того, как в рацион животным добавляли масло из зародышей пшеницы и листья зелени. Ученые предположили, что в этих продуктах присутствует некий фактор, который поддерживает репродуктивную функцию. Данный фактор назвали токоферолом (от др. греч. tos - дети, phero - рожать), или вит. Е. В 1931 г. были описаны антиоксидантные свойства нового витамина и последствия его дефицита. В 1936 г. альфа-токоферол выделили из натурального сырья, из масла ростков пшеницы. В 1938 г. была описана его химическая структура, и в этом же году это вещество получили синтетическим путем. И сразу же вит. Е начали использовать в клинической практике. В последующие десятилетия изучение структуры и свойств вит. Е было продолжено.

Витамин Е не является каким-то одним конкретным веществом. Витамеры Е именуют токоферолами и токотриенолами. Насчитывается восемь витамеров Е: четыре токоферола и четыре токотриенола. И те, и другие обозначаются буквами греческого алфавита (альфа, бета, гамма, сигма). Все они имеют во многом сходную пространственную молекулярную структуру, 
и различаются между собой лишь в деталях. Отличительная черта токотриенолов: они имеют три двойных связи в молекуле. По сравнению с токотриенолами токоферолы более активны. Самый известный из токоферолов - альфа-токоферол, вещество с формулой $\mathrm{C}_{29} \mathrm{H}_{50} \mathrm{O}_{2}$ и названием 6-Ацетокси-2-метил-2-(4,8,12триметилтридецил)-хроман. Бета-токоферол слабее альфа-токоферола в два раза, а гамма-токоферол - в 10 раз. Но все восемь токоферолов и токотриенолов обозначают общим термином «токоферол». Все токоферолы и токотриенолы представляют собой бесцветные или желтые жидкости. Данные вещества хорошо растворяются в жирах и в органических растворителях (спирт, ацетон, эфир), но не растворяются в воде. Они устойчивы к действию высоких температур, но не устойчивы к действию кислорода и других окислителей, а также к ультрафиолетовому излучению. Во внешней среде на солнце и на воздухе они быстро разлагаются, однако стойки к действию кислот и щелочей.

\section{Основы метаболизма}

Токоферолы в составе пищевых продуктов и синтетических препаратов поступают в ЖКТ. Их всасывание происходит в тонком кишечнике в присутствии желчи. На этот процесс влияет состав пищи. Поскольку витамин Е является жирорастворимым, то чем больше в пище жиров, тем лучше происходит всасывание. Витамин Е в тонком кишечнике всасывается в составе хиломикронов, органических соединений класса липопротеинов. Затем определенная часть токоферолов связывается в печени со специфическими белками. В соединении с этими белками или в составе хиломикронов вит. Е доставляется к органам и тканям. Далее эти соединения распадаются, и токоферолы поступают внутрь клеток с помощью пассивной диффузии. В печени вит. Е подвергается метаболическим превращениям. Выводится он из организма в неизменном виде или в виде метаболитов с калом $(90 \%)$ и с мочой $(10 \%)$. Поскольку вит. Е яв- 
ляется жирорастворимым, он может кумулироваться. Значительное количество витамина накапливает печень. Также он может накапливаться в надпочечниках, в мышцах и в жировой ткани. Витамин Е очень плохо проникает через плацентарный барьер. Поэтому его содержание в крови плода составляет лишь 20-30 \% от содержания в крови матери. Некоторая часть вит. Е проникает в грудное молоко.

\section{Физиологические функции}

Витамин Е наряду с витаминами А и С является одним из наиболее мощных антиоксидантов. Эти вещества, антиоксиданты, известны тем, что угнетают реакции перекисного окисления, которые протекают с участием свободных радикалов - частиц, имеющих на внешней орбите атомов один или несколько неспаренных электронов. Из-за этих неспаренных электронов свободные радикалы обладают повышенной реактогенной способностью. Они легко и быстро вступают во взаимодействие со многими веществами - белками, нуклеиновыми кислотами (ДНК и РНК) и жирами (липидами), подвергая их свободнорадикальному окислению (СРО). В роли свободных радикалов, как правило, выступают атомы кислорода в виде активных форм (АФК). Повышенная реактогенность АФК приводит к тому, что они легко вступают во взаимодействие с липидными структурами клеточных мембран - развивается перекисное окисление липидов (ПОЛ). В ходе ПОЛ обеспечивается проницаемость клеточной мембраны для различных веществ. Благодаря этому процессу клетка растет и делится, обновляются ткани, происходит синтез некоторых важных для организма соединений.

В некоторых ситуациях ПОЛ имеет и позитивные физиологические свойства. Но лишь в тех случаях, когда оно контролируется антиоксидантной системой и протекает не слишком быстро и интенсивно, а «в меру». Однако во многих случаях процесс становится неконтролируемым. Период существования 
свободных радикалов невелик - доли секунды. В ходе ПОЛ изменяются структуры липидов клеточных мембран. Соответственно, изменяется и свойства самой мембраны. Она становится гидрофильной, проницаемой для воды. Вместе с водой в клетку извне проникают токсические вещества, и в конечном итоге клетка погибает. При этом измененные при ПОЛ мембранные липиды превращаются в гидроперекиси, т.е. сами становятся свободными радикалами. Развивается цепная реакция, в которую вовлекаются все новые и новые клетки тканей. СРО подвергаются не только липиды, но и белки с нуклеиновыми кислотами. Нарушается деление и рост клеток, передача генной информации. Это не может не отразиться на состоянии органов и тканей. Реакции ПОЛ ингибируются антиоксидантной системой, иначе мы бы не смогли существовать. Антиоксидантная система включает в себя множество звеньев - ферментов, гормонов, витаминов и других биологически активных веществ. Токоферол относится к истинным неферментным антиоксидантам. Боковые цепи молекул токоферола вступают во взаимодействие с ненасыщенными жирными кислотами липидов клеточных структур. Образуется комплекс, устойчивый к действию АФК. Патологическая цепная реакция прерывается, и ПОЛ прекращается.

Наряду со своим основным антиоксидантным действием вит. Е участвует в синтезе многих веществ, а также предотвращает окисление и усиливает физиологические эффекты вит. А.

Со стороны систем органов и тканей действие токоферола проявляется следующим образом.

- Сердечно-сосудистая система. Препятствует дистрофическим изменениям в сердечной мышце, обеспечивает должную силу сердечных сокращений. Предотвращает развитие атеросклероза сосудов, снижает проницаемость сосудистой стенки. Снижает повышенное АД.

- Система кроветворения. Благодаря вит. Е продлевается срок жизни эритроцитов. Кроме того, токоферолы участвуют в синтезе гема (небелкового железосодержащего компонента гемоглобина). Также токоферолы регулируют процессы сверты- 
вания крови, предотвращая появление избыточного образования тромбоцитов и тем самым препятствуя патологическому образованию тромбов. В целом на кровь токоферолы действуют разжижающее - они усиливают ее текучесть и облегчают доставку кислорода с кровью к тканям.

- Иммунная система. Витамин Е стимулирует многие звенья иммунитета, повышает сопротивляемость организма к инфекциям.

- Дыхательная система. Повышает устойчивость альвеол, слизистой оболочки бронхов и верхних дыхательных путей к действию инфекционных агентов, сухого горячего или холодного воздуха, многих веществ, загрязняющих атмосферу. Витамин Е позитивно влияет на состояние диафрагмы, регулирует ее тонус и сократимость. Благодаря подвижности диафрагмы внешнее дыхание становится качественным, полноценным.

- Костно-мышечная система. Повышает мышечную силу и выносливость. При регулярных тренировках способствует увеличению мышечной массы. Благодаря этому витамину мышцы быстрее восстанавливаются после физических нагрузок. Участвует в синтезе коллагена, обеспечивающего прочность костей, связок и сухожилий.

- Кожа и ее производные. Благодаря синтезу коллагена и эластина повышается упругость и эластичность кожи. В этом отношении вит. Е оказывает омолаживающее действие. Этот витамин способствует заживлению ран, изъязвлений и ожогов кожи и слизистых оболочек. Препятствует появлению пигментных пятен.

- Нервная система. Улучшая мозговое кровообращение, вит. Е предупреждает развитие инсультов. Также этот витамин стимулирует мышление и память, и в старческом возрасте предупреждает развитие болезни Альцгеймера.

- Органы зрения. Предупреждает развитие катаракты и дистрофии сетчатки, повышает остроту зрения.

- Эндокринная система. Стимулирует выработку инсулина и нормализует уровень глюкозы в крови при ее повышении. Тем самым предотвращает развитие СД. 


\section{Содержание в продуктах, суточные нормы потребления}

В процессе жизнедеятельности в нашем организме постоянно образуются радикалы, которые запускают ПОЛ. Активация ПОЛ требует все новых и новых поступлений антиоксидантов. Поэтому эти две системы, окислительная и антиоксидантная, нейтрализуют друг друга, и находятся в состоянии динамического равновесия. Как только повышается количество АФК или снижается количество антиоксидантов, запускаются процессы ПОЛ со всеми вытекающими негативными последствиями. В принципе вит. Е, будучи жирорастворимым, способен хорошо накапливаться в организме в количествах, достаточных для полноценной антиоксидантной защиты (табл. 27, 28).

Таблица 27

Рекомендуемые нормы потребления токоферола

\begin{tabular}{|l|c|}
\hline \multicolumn{1}{|c|}{ Категория } & Норма, мг \\
\hline Младенцы до 6 мес. & 3 \\
\hline Младенцы от 6 мес. до года & 4 \\
\hline Дети 1-3 лет & 6 \\
\hline Дети 4-10 лет & 7 \\
\hline Мальчики-подростки старше 11 лет и взрослые мужчины & 10 \\
\hline Девушки-подростки и взрослые женщины & 8 \\
\hline Беременные женщины & 10 \\
\hline Кормящие женщины & 12 \\
\hline
\end{tabular}

Таблица 28

Содержание токоферола в продуктах питания

\begin{tabular}{|l|c|}
\hline \multicolumn{1}{|c|}{ Продукт } & Содержание, мг/100 г \\
\hline Масло подсолнечное & 44 \\
\hline Масло кукурузное & 93 \\
\hline Крупа гречневая & 6,65 \\
\hline Соя & 17,3 \\
\hline Горох & 9,4 \\
\hline Миндаль & 24,6 \\
\hline
\end{tabular}


Окончание табл. 28

\begin{tabular}{|l|c|}
\hline \multicolumn{1}{|c|}{ Продукт } & Содержание, мг/100 г \\
\hline Фундук & 21 \\
\hline Кедровый орех & 10,1 \\
\hline Арахис & 9,3 \\
\hline Отруби пшеничные & 10,4 \\
\hline Грецкий орех & 6,4 \\
\hline Тыквенные семечки & 15 \\
\hline Ростки пшеницы & 24 \\
\hline Печень трески (консервированная) & 8,8 \\
\hline Шпроты (консервированные в масле) & 8,8 \\
\hline Черная икра & 4 \\
\hline Угорь & 5 \\
\hline Курага & 5,5 \\
\hline Облепиха & 10,3 \\
\hline Соя & 17,3 \\
\hline Горох & 9,4 \\
\hline Зеленый горошек & 2,6 \\
\hline Куриное яйцо & 2 \\
\hline Говяжья печень & 1,28 \\
\hline
\end{tabular}

\section{Симптомы дефицита и избытка}

Дефициту вит. Е способствуют следующие факторы:

- сезонный недостаток вит. Е. Поскольку этот витамин содержится преимущественно в растительных продуктах, то можно предположить, что весной мы будем испытывать его дефицит;

- гиповитаминоз C;

- интоксикации. Поступление в организм токсичных веществ (промышленные и бытовые яды), длительное применение ряда лекарственных препаратов (антибиотиков);

- высококалорийное питание. При избыточном поступлении высококалорийной пищи с избытком жиров и углеводов возникает нехватка обычных окислителей. Поэтому для того, чтобы все это утилизировать, запускаются процессы СРО; 
- малоподвижный образ жизни. При низкой физической активности замедляются ферментативные процессы биологического окисления. Чтобы как-то восполнить имеющийся пробел и ускорить окисление, запускается СРО;

- стрессы. При психоэмоциональных нагрузках активируется симпатическая вегетативная нервная система. Происходит усиленный выброс катехоламинов - адреналина и норадреналина. Действие катехоламинов направлено на образование свободных радикалов. Ионизирующее излучение также способствует образованию свободных радикалов;

- заболевания ЖКТ, печени и желчного пузыря (нарушается всасывание вит. Е в тонком кишечнике).

Активация СРО и ПОЛ при недостатке вит. Е запускает цепь негативных процессов во всех системах органов. Страдает кроветворение. Разрушаются мембраны эритроцитов, и происходит массивный гемолиз. Это автоматически приводит к анемии и гипоксии (дефициту кислорода) в тканях.

Гиповитаминоз Е усугубляет тяжесть течения гемолитической болезни новорожденных. Это заболевание обусловлено резус-конфликтом матери и плода и протекает с отеками, желтухой и анемией. Недоношенность также иногда сопровождается гемолитической анемией.

Свободные радикалы повреждают эндотелий сосудов. На поврежденном эндотелии быстрее образуются атеросклеротические бляшки и тромбы, закупоривающие сосудистый просвет. Нарушение кровотока по коронарным сосудам провоцирует ИБС.

Свободные радикалы вызывают денатурацию многих белков. Один из таких белков - миозин, который обеспечивает силу мышечных сокращений. Разрушение этого белка сопровождается снижением силы мышечных сокращений. Снижается тонус мышц, они становятся менее устойчивыми к гипоксии. Со стороны миокарда это проявляется сердечной недостаточностью, явлениями кардиосклероза с высоким риском аритмий и инфаркта миокарда. 
Аналогичные процессы в скелетных мышцах приводят к снижению мышечной силы и выносливости Дистрофические процессы в диафрагме приводят к ограничению ее подвижности во время дыхания и к недостаточной вентиляции легких. Возникают частые респираторные инфекции и хроническая дыхательная недостаточность, которая лишь усугубляет тканевую гипоксию.

Снижение иммунитета также способствует учащению инфекционных заболеваний.

В процессе ПОЛ наряду со свободными радикалами образуются другие классы органических соединений: альдегиды, эпоксиды, кетоны. Все они, как правило, токсичны и поражают печень, головной мозг. К тому же некоторые из этих веществ оказывают канцерогенное действие. Росту злокачественных опухолей способствует и тот факт, что при СРО изменяется ДНК, и клетки принимают атипичные черты. Нарушение желчеобразующей функции печени, угнетение моторики гладкой мускулатуры ЖКТ приводит к мальабсорбции, снижению всасывательной способности кишечника. В итоге организм испытывает дефицит многих полезных веществ - белков, витаминов, микроэлементов. Нарушение всасывания жиров в тонком кишечнике проявляется стеатореей, жирным калом.

При гиповитаминозе Е страдает эндокринная функция, снижается продукция многих гормонов. Дефицит инсулина провоцирует сахарный диабет, а недостаток щитовидных и надпочечниковых гормонов - другие виды обменных нарушений.

Снижение синтеза половых гормонов крайне отрицательно сказывается на сексуальности и детородной функции и проявляется снижением либидо, бесплодием. При наступившей беременности возможны самопроизвольные выкидыши и преждевременные роды, а также патологическое течение родового акта.

Вещество головного мозга также страдает при дефиците вит. Е. Атеросклероз и тромбоз мозговых сосудов приводят к инсультам. Из-за нарушения обменных процессов мозговая 
ткань претерпевает дистрофические изменения и размягчается. Клинически это проявляется энцефалопатией (угнетением мозговых функций) и болезнью Альцгеймера.

Еще один признак гиповитаминоза Е - это раннее старение. Кожа становится сухой, дряблой, морщинистой, покрытой пигментными пятнами. Эти пятна - не что иное, как липофусцин, смесь липидов и денатурированных белков. Данное вещество не утилизируется, а накапливается в клетках кожи, придавая ей характерный вид.

Хотя токоферолы и накапливаются в организме, они не токсичны. Поэтому гипервитаминоз Е в клинической практике встречается редко, в основном при массивном поступлении лекарственных форм токоферола. В этих случаях отмечаются подъемы АД, тошнота, боли в животе, метеоризм, диарея. Но все эти симптомы непродолжительны, и прекращаются после отмены препаратов вит. Е.

\section{Участие в репродукции}

Витамин Е является источником синтеза и кофактором стероидных гормонов, особенно - эстрогенов. В настоящее время, ввиду популярности безжировой диеты и аналогичного типа питания, направленным на снижение холестерина и ЛПНП, сформировалась группа витамин-Е-дефицитных пациентов. На уровне рецепторов эндометрия токоферол обладает эстрогеноподобным действием, но при этом снижает уровень патологической пролиферативной активности гормонозависимых тканей и клеток (в том числе молочных желез). Основной эффект его состоит в восстановлении баланса стероидных гормонов в сочетании с мощной антиоксидантной и иммуномодулирующей активностью и другими эффектами.

Можно рекомендовать дополнительный прием вит. Е женщинам ювенильного, репродуктивного и менопаузального перио- 
дов и беременным при дисбалансе эндокринной системы любого генеза, нарушениях менструального цикла, рецепторном дефиците эстрогенов, при подготовке к беременности - в группах риска по невынашиванию или пациентам с гиповитаминозом. Эффективно применение вит. Е на прегравидарном этапе и до 12 недель беременности вследствие его влияния на инвазию трофобласта и готовность эндометрия.

В последнее время широко обсуждается роль вит. Е и в профилактике снижения сперматогенеза у мужчин, что связано с его антиоксидантным потенциалом и способностью стабилизации мембран сперматозоидов. Предполагается, что вит. Е в комбинации с селеном необходим для нормального процесса сперматогенеза. Однако этот вопрос требует дальнейшего изучения.

\section{Акушерские и перинатальные результаты дефицитарных состояний}

Витамин Е участвует в процессах тканевого дыхания и метаболизме белков, жиров и углеводов. Также вит. Е - это антиоксидант, он защищает организм от вредного воздействия свободных радикалов. Дефицит вит. Е приводит к проблемам в организме и матери, и ребенка.

Литературные данные по изучению недостатка вит. Е при беременности весьма противоречивы, и доза вит. Е является обсуждаемой, однако в целом не должна превышать $400 \mathrm{ME}$. При этом существуют также данные о 100 или 200 ME как о максимальной суточной дозе. Единой позицией по поводу дозы вит. Е при беременности не существует, следовательно, доза свыше $100 \mathrm{ME} \mathrm{в} \mathrm{сутки} \mathrm{должна} \mathrm{иметь} \mathrm{обоснование.} \mathrm{Дефицит} \mathrm{вит.} \mathrm{Е} \mathrm{при}$ беременности при плазменной концентрация токоферола менее 12 ммоль/л связан с увеличением частоты инфекций у матери, анемией матери, задержкой роста плода и неблагоприятными исходами беременности для матери и ребенка. 
Результаты проведенных экспериментальных исследований на животных продемонстрировали, что вит. Е является незаменимым для правильного развития плода у крыс. Состояния, связанные с нарушением поглощения вит. Е, приводят к эмбриональной летальности и у мышей. Однако нет достоверных данных, подтверждающих, что возможной причиной нарушения эмбриогенеза у людей является дефицит вит. Е, $\alpha$-ТТР.

В норме при беременности происходит увеличение в крови $\alpha$-токоферола, что ассоциировано с увеличением концентрации липидов. Выявлено, что при патологическом течении гестации концентрация в крови $\alpha$-токоферола ниже, чем при физиологической беременности соответствующего гестационного срока. Согласно литературным данным, не существует четкой связи между концентрацией вит. Е в крови матери и плода. Краткосрочный прием вит. Е беременными женщинами перед родами значительно повышает статус вит. Е только у матери. Считается, что вит. Е недостаточно эффективно проходит через плаценту в кровоток ребенка. Механизмы регуляции плацентарной передачи остаются окончательно неизученными, предполагается регулирующая роль $\alpha$-ТТР по переносу $\alpha$-токоферола через плацентарный барьер.

Витамин Е является витамином с антиоксидантным действием. В настоящее время обсуждается роль оксидативного стресса в патогенезе преэклампсии и эклампсии. Предполагается, что витамины с антиоксидантным потенциалом могут иметь положительный терапевтический эффект при назначении беременным из групп риска. Раннее назначение антиоксидантов, таких как вит. Е и $\mathrm{C}$, для женщин с высоким риском развития преэклампсии может иметь клиническое значение. Выявлено, что происходит улучшение функции эндотелия и определяется меньшая степень выраженности плацентарной дисфункции. Дефицит вит. Е у недоношенных детей сопровождается гемолитической анемией и вызывает нарушения зрения. Риск возникновения этих заболеваний у доношенных детей при дефиците вит. Е также достаточно высокий. 


\section{Способы лабораторной диагностики}

Измерение содержания в плазме крови $\alpha$-токоферола является наиболее прямым и достоверным методом диагностики. У взрослых дефицит вит. Е предполагается, если содержание $\alpha$-токоферола составляет менее 5 мкг/мл (менее 11,6 мкмоль/л). Исследование гемолиза эритроцитов с перекисью позволяет предположить диагноз, однако данный тест является неспецифичным. Аномальные уровни липидов плазмы крови могут влиять на статус вит. Е, наиболее точным показателем у взрослых с гиперлипидемией является низкое соотношение $\alpha$-токоферола с общим количеством липидов (менее $0,8 \mathrm{мг} / \Gamma$ общего количества липидов). У детей и взрослых с абеталипопротеинемией содержание в плазме крови $\alpha$-токоферола, как правило, определить не удается

\section{Варианты коррекции}

В клинической практике используется отечественный синтетический аналог вит. Е - альфа-токоферола ацетат. Формы выпуска: 10\%-ный и 30\%-ный масляный раствор для приема внутрь, капсулы с масляным раствором, содержащие 100 и 200 мг вит. Е 5\%-ный и 10\%-ный масляный раствор для внутримышечных инъекций (внутривенно масляные растворы не вводят). Зарубежные производители выпускают препарат под названием «Витамин Е», содержащий 100; 200 и $400 \mathrm{ME}$ действующего вещества. Витамин Е также входит в состав препаратов «Эвитол», «Доппельгерц», «Витрум» и других комбинированных средств.

\section{Взаимодействие}

Прием гормональных контрацептивов, антибиотиков, приводит к уменьшению количества вит. Е. Этот витамин усиливает действие нестероидных противовоспалительных средств, 
средств для лечения эпилепсии. Токоферолы снижают токсическое действие сердечных гликозидов. Они усиливают действие непрямых антикоагулянтов, что может привести к кровотечению. Витамин Е усиливает действие инсулина. Это нужно учитывать больным сахарным диабетом, принимающим инсулин, так как возможно развитие гипогликемии.

Известно, что токоферол снижает эффективность препаратов, используемых при химиотерапии. Витамин Е предохраняет ПНЖК от разрушения. Однако эти соединения угнетают всасывание токоферолов в кишечнике. Селен уменьшает потребность организма в вит. Е. В свою очередь вит. Е предохраняет селен от окисления, а также замедляет всасывание калия. Гиповитаминоз токоферола приводит к дефициту магния. Некоторые виды железосодержащих препаратов могут его разрушать. Медь окисляет вит. Е. Токофрол усиливает действие ретинола и предохраняет его от окисления. Вместе с этим витамином он участвует в синтезе кофермента Q, или убихинона, обеспечивающего внутриклеточный транспорт кислорода. Также вит. Е активирует вит. D в печени и стимулирует обмен кальция. Витамин С усиливает действие токоферола, что делает комбинацию этих витаминов желательной. А вот сочетать его с вит. К не стоит, так как эти витамины являются антагонистами по отношению друг к другу. 


\section{ТЕСТОВЫЕ ЗАДАНИЯ}

1. К клиническому проявлению глубокого дефицита витамина РР относят:
a) ксерофтальмию
b) полиневрит
c) пеллагру
d) цингу

2. Потребность взрослого человека в витамине РР составляет (в мг):
a) 3
b) 90
c) 5
d) 20

3. Удовлетворение потребности организма в витаминах $\mathrm{B}_{1}, \mathrm{~B}_{2}, \mathrm{~B}_{6}$ достигается:

a) употреблением в пищу продуктов переработки зерен злаков (хлеб, макароны и т.п.)

b) употреблением в пищу овощей и фруктов

c) эндогенным синтезом при ультрафиолетовом облучении

d) употреблением в пищу продуктов животного происхождения (молоко, яйца, мясо)

4. Наибольшее количество полиненасыщенных жирных кислот семейства омега-3 содержится в масле:
a) оливковом
b) кукурузном
c) льняном
d) подсолнечном 
5. К пищевым продуктам - основным источникам витамина А относят:

a) цитрусовые, шиповник, черную смородину

b) рыбий жир, масло сливочное

c) масло растительное, зерновые продукты

d) крупу гречневую, дрожжи пекарские

6. В образовании костной ткани участвует витамин
a) $\mathrm{D}$
b) $\mathrm{PP}$
c) $\mathrm{K}$
d) $\mathrm{B}_{2}$

7. При термической обработке продуктов наибольшему разрушению подвергается витамин
a) $\mathrm{C}$
b) $\mathrm{B}_{12}$
c) $\mathrm{A}$
d) фолиевая кислота

8. Тиамин участвует преимущественно в обмене
a) белковом
b) углеводном
c) липидном
d) минеральном

9. Витамином-антиоксидантом, встроенным в биомембрану клетки, является
a) альфа-токоферол
b) бета-каротин
c) аскорбиновая кислота
d) ретинол 
10. При дефиците ретинола может диагностироваться

a) увеличение времени темновой адаптации

b) хейлоз

c) кровь при чистке зубов

d) дисфагия

11. К водорастворимым витаминам относят:

a) рибофлавин

b) викасол

c) токоферол

d) ретинол

12. Во время беременности возрастает потребность в витаминах
a) $\mathrm{B}_{1}$ и $\mathrm{C}$
b) А и $\mathrm{E}$
c) $\mathrm{D}$ и фолиевой кислоты
d) $\mathrm{C}$ и $\mathrm{PP}$

13. Дефицит йода в рационе питания приводит к повышению риска развития заболеваний:

a) поджелудочной железы

b) щитовидной железы

c) дыхательной системы

d) надпочечников

14. Удовлетворение потребности организма в цианокобаламине достигается:

a) употреблением в пищу продуктов животного происхождения (молоко, яйца, мясо)

b) употреблением в пищу овощей и фруктов

c) эндогенным синтезом при ультрафиолетовом облучении

d) употреблением в пищу продуктов переработки зерен злаков (хлеб, макароны и др) 
15. Симптомом дефицита пиридоксина является:
a) себорея
b) хейлоз
c) цилиарная инъекция
d) фолликулярный гиперкератоз

16. Избыток углеводов в питании вызывает увеличение потребности в
a) фолатах
b) тиамине
c) аскорбиновой кислоте
d) пиридоксине

17. Возникновение D-гипервитаминоза возможно при условии приема
a) больших доз кальция
b) большого количества обычного рыбьего жира
c) большого количества печени морских рыб
d) больших доз витамина D

18. К витаминоподобным соединениям относят:
a) рибофлавин
b) тиамин
c) пиридоксин
d) инозит

19. При выраженном дефиците рибофлавина может наблюдаться анемия
a) нормохромная нормоцитарная
b) гиперхромная макроцитарная
c) гипохромная нормоцитарная
d) нормохромная микроцитарная 
20. Себорейный дерматит, судороги, жировая инфильтрация печени - проявления авитаминоза витамина
a) $\mathrm{PP}$
b) $\mathrm{A}$
c) $\mathrm{B}_{6}$
d) $\mathrm{B}_{1}$

21. Фрукты и овощи обеспечивают организм витаминами

a) C, фолиевая кислота, каротин

b) фолиевая кислота, D, $\mathrm{B}_{6}$

c) A, D, E

d) $\mathrm{B}_{1}, \mathrm{C}, \mathrm{P}$

22. Длительное поступление ретинола в период беременности в количестве более трех физиологических норм может привести к:
a) тератогенному эффекту
b) аллергическим реакциям
c) канцерогенному эффекту
d) острому отравлению

23. К пищевым источникам витамина $\mathrm{B}_{12}$ относят

a) печень, почки, сердце жвачных животных, мясо

b) рыбий жир, масло сливочное

c) крупу гречневую, дрожжи пекарские

d) цитрусовые, шиповник, черную смородину

24. При недостаточном поступлении с рационом морской рыбы может возникнуть дефицит
a) полиненасыщенных жирных кислот семейства омега-3
b) полиненасыщенных жирных кислот семейства омега-6
c) полиненасыщенных жирных кислот семейства омега-9
d) мононенасыщенных жирных кислот 
25. К фолатзависимым врожденным порокам развития плода относятся:

a) дефекты развития нервной трубки

b) пороки сердца

c) гипоплазия легких

d) анэнцефалия 


\section{ЭТАЛОНЫ ОТВЕТОВ НА ТЕСТОВЫЕ ЗАДАНИЯ}

$$
\begin{aligned}
& 1-\mathrm{c}, 2-\mathrm{d}, 3-\mathrm{a}, 4-\mathrm{c}, 5-\mathrm{b}, 6-\mathrm{a}, 7-\mathrm{d}, 8-\mathrm{b}, 9-\mathrm{a}, 10-\mathrm{a}, 11-\mathrm{a}, \\
& 12-\mathrm{c}, 13-\mathrm{b}, 14-\mathrm{c}, 15-\mathrm{b}, 16-\mathrm{b}, 17-\mathrm{d}, 18-\mathrm{d}, 19-\mathrm{a}, 20-\mathrm{c}, \\
& 21-\mathrm{a}, 22-\mathrm{a}, 23-\mathrm{a}, 24-\mathrm{a}, 25-\mathrm{a} .
\end{aligned}
$$




\section{ЗАДАЧИ}

\section{Задача 1.}

Н., 43 года, обратилась в женскую консультацию по поводу желанной беременности с целью встать на учет. На момент обращения жалоб не предъявляет. Срок гестации 10-11 недель. Из анамнеза: данная беременность пятая. Первые две закончились медицинскими абортами в малых сроках по желанию женщины (оба раза посредством выскабливания полости матки), третья беременность - срочные роды (беременность осложнилась тяжелой преэклампсией), четвертая беременность - срочные роды без осложнений. Рост 164 см, вес 82 кг. Хронические заболевания АГ 1-й ст., 2-й степени, риск 3.

Задание:

1. Сформулируйте диагноз.

2. Составьте план необходимой витаминной поддержки.

\section{Задача 2.}

К., 23 года, обратилась в женскую консультацию по рекомендации врача-эндокринолога, у которого проходит обследование по поводу ожирения. Менструации с 15 лет, по 4-5 дней через 30-35 дней, скудные. В последние два года отмечает удлинение цикла до 50 дней. Половой жизнью живет, контрацепцию не использует, в наступлении беременности заинтересована. Рост 165 см, вес 94 кг. На поверхности живота, бедер - растяжки багрового цвета. Пациентка отмечает повышенный рост волос по всему телу, по поводу чего походит курс лазерной эпиляции (подобрала сама). На коже лица, спины, груди - акне.

Задание:

1. Сформулируйте диагноз.

2. Составьте план дообследования.

3. Составьте план необходимой витаминной поддержки. 


\section{ЭТАЛОНЫ ОТВЕТОВ НА ЗАДАЧИ}

\section{Задача 1.}

1. Диагноз: беременность 10-11 недель. ОАГА. АГ 1-й ст., 2-й степени, риск 3. Ожирение 1-й ст.

2. Калия йодид -250 мкг/сут во время всей беременности.

Фолиевая кислота - 5 мг/сут.

Витамин D - 2000 ЕД/сут, возможно увеличение дозировки при выявленном лабораторными методами дефиците.

Омега-3-ПНЖК - 300 мг/сут.

\section{Задача 2.}

1. СПКЯ.

2. Для уточнения диагноза и формы требуется провести дообследование: оценка гирсутизма по шкале Ферримана, УЗИ органов малого таза. Кровь на тестостерон свободный, ДГАЭС, пролактин, ССПГ (секс-стероид-связывающий глобулин), прогестерон, 17-ОН-прогестерон, кортизол, глюкоза, инсулин, ПГТТ (пероральный глюкозотолерантный тест), ТТГ, Т 4 свободный.

3. Витамин D - 2000 ЕД/сут, увеличение дозировки при выявленном лабораторными методами дефиците.

Инозитол (миоинозитол) - 1000 мг/сут.

Фолиевая кислота - 4 мг/сут. 


\title{
Учебное издание
}

\author{
Авторы: \\ Падруль Михаил Михайлович, \\ Олина Анна Александровна, \\ Садыкова Гульнара Камильевна, \\ Прохорова Ольга Валентиновна, \\ Метелева Татьяна Александровна, \\ Ширинкина Елена Викторовна, \\ Статных Наталья Владимировна
}

\section{ЗНАЧЕНИЕ ВИТАМИНОВ В АКУШЕРСКО-ГИНЕКОЛОГИЧЕСКОЙ ПРАКТИКЕ}

\author{
Учебное пособие
}

Редактор и корректор М.Н. Афанасьева

Подписано в печать 16.04.2021. Формат 60×90/16.

Усл. печ. л. 10,3. Тираж 60 экз. Заказ № 79/2021.

ИП Серегина О.Н.

Адрес: 614107, г. Пермь, ул. Металлистов, д. 21, кв. 174. 